
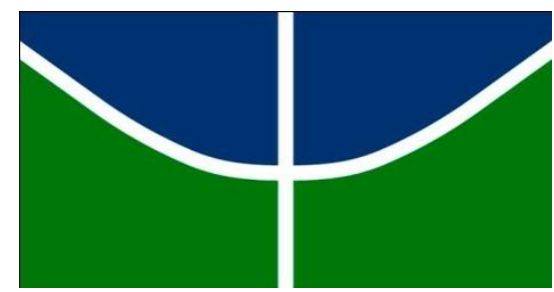

UNIVERSIDADE DE BRASÍLIA

INSTITUTO DE BIOLOGIA

DEPARTAMENTO DE BOTÂNICA

PROGRAMA DE PÓS-GRADUAÇÃO EM BOTÂNICA

\title{
A Subtribo Oncidiinae Benth. (Orchidaceae Juss.) no Distrito Federal, Brasil
}

VIVIANE VAZ DE QUEIROZ

Brasília - DF 
UNIVERSIDADE DE BRASÍLIA

INSTITUTO DE BIOLOGIA

DEPARTAMENTO DE BOTÂNICA

PROGRAMA DE PÓS-GRADUAÇÃO EM BOTÂNICA

\title{
A Subtribo Oncidiinae Benth. (Orchidaceae Juss.) no Distrito Federal, Brasil
}

\author{
VIVIANE VAZ DE QUEIROZ
}

ORIENTADOR: PROF. DRA. CAROLYN ELINORE BARNES PROENÇA

Dissertação apresentada ao Programa de Pós-Graduação em Botânica do Instituto de Biologia da Universidade de Brasília, em cumprimento às exigências para obtenção do grau de Mestre em Botânica. Área de Concentração: Taxonomia vegetal.

Brasília - DF 
QUEIROZ, Viviane Vaz.

A Subtribo Oncidiinae Benth. (Orchidaceae Juss.) no Distrito Federal, Brasil/ Viviane Vaz de Queiroz; Orientação de Carolyn Elinore Barnes Proença - Brasília DF, 2015.

p.: Il.

Dissertação (Mestrado) - Instituto de Ciências Biológicas da Universidade de Brasília/ Departamento de Botânica, 2015.

1. Distrito Federal 2. Florística 3. Oncidiinae 4. Orchidaceae 5. Taxonomia 


\section{A Subtribo Oncidiinae Benth. (Orchidaceae Juss.) no Distrito Federal, Brasil}

\section{Aprovada por:}

Prof. Dra. Carolyn Elinore Barnes Proença

Presidente da banca examinadora (orientador)

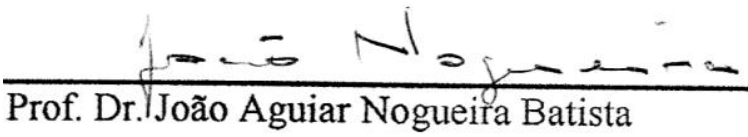

(Membro Titular da Banca Examinadora)

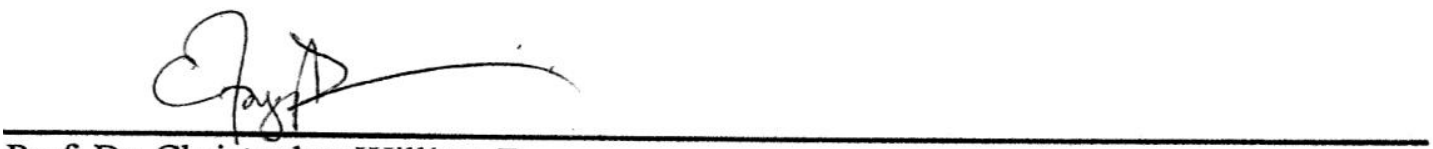

Prof. Dr. Christopher William Fagg

(Membro Titular da Banca Examinadora)

Prof. Dra. Renata Côrrea Martins

(Membro Suplente da Banca Examinadora)

Brasília, 23 de Fevereiro de 2015 
"Espera no Senhor, anima-te; e ele fortalecerá o teu coração; espera, pois, no Senhor." Sl 27:14 


\section{AGRADECIMENTOS}

Agradeço em primeiro lugar a Deus, que me deu o dom da vida e do amor, e que me fortalece e abençoa todos os dias. E Nossa Senhora que intercede por mim.

A minha família querida, mãe, pai, avôs, avós, irmãos, tios e primos, que sempre me incentivam em meus sonhos, e que acreditam que sou um orgulho para eles.

A minha irmã amada Raianny, minha companheira que sonha comigo e que motiva a ir atrás do que eu quero, e está sempre ao meu lado...

A minha mãe que me ama e torce por mim...

Ao meu irmão Fábio que pega no meu pé todos os dias, mas que amo muito...

Ao meu tio Ronaldo que amo infinitamente, que me apóia em tudo...

A minha Vó Geralda que cuida de mim incasavalmente e que sempre me escuta, sem entender nada e que faz de tudo pelos netos, até cuidar dos animais...

Ao meu avô paterno Sebastião que me apóia e me tem como uma boa neta, e in memória avó Sebastiana que sempre torcia por mim e que jamais imaginou que eu entraria num mato para pesquisar, e sorria ao falar "você subindo numa árvore, acho difícil minha filha" e que rezava muito por mim...

As minhas amigas que me escutam e que torcem por mim: Bárbara, Inara, Josiana, Kézia e Rachel... E as demais...

Ao meu namorado Daniel, querido e companheiro, que me ajudava, e às vezes colocava a mão na massa comigo...

A Carol minha orientadora, que pra mim foi um presente de Deus, que confiou numa pessoa em primeiro momento sem experiência em plantas e que me deu oportunidade de trabalhar de cara com taxonomia e me fez se apaixonar pelas plantas... Uma mãe e uma amiga...

Ao Luciano Bianchetti, meu co-orientador "informal", que foi um presente que Deus escolheu a dedo, por sua dedicação e paciência comigo. De me ensinar tudo sobre as Orquídeas... Um grande amigo.

Ao professor Christopher Fagg pelo apoio e bolsa concedida pelo PROTAX/CNPq, processo 562340/2010-6.

A todos os docentes, alunos de turma e amigos que conheci no Departamento de Botânica, em especial a Ísis Rhaysa, João Lucas, Josemília e José Herlânio, e aos funcionários do herbário que me incentivaram e me ajudaram. 


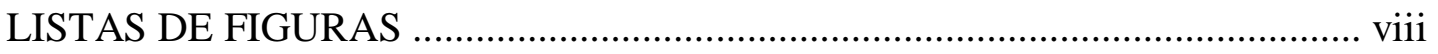

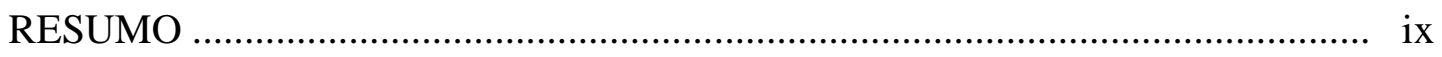

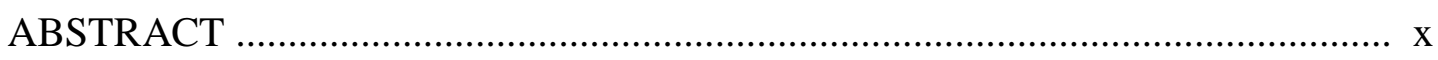

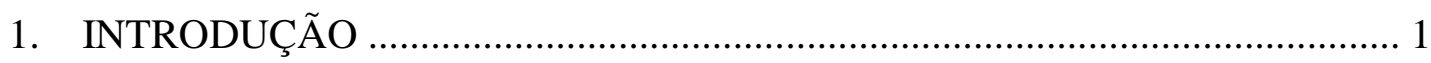

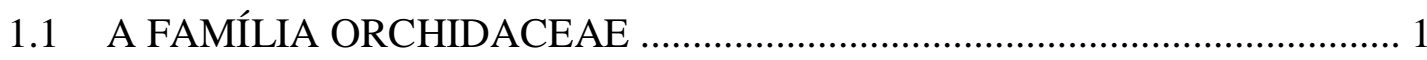

1.2. A SUBTRIBO ONCIDIINAE BENTH. ..................................................... 4

1.3. DIVERSIDADE E DISTRIBUIÇÃO NO BRASIL ..................................... 7

1.4. DIVERSIDADE E DISTRIBUIÇÃO NO BIOMA CERRADO ...................... 8

1.5. DIVERSIDADE E DISTRIBUIÇÃO NO DISTRITO FEDERAL ................. 8

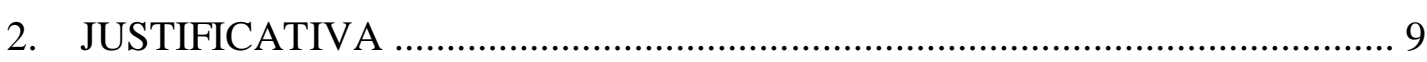

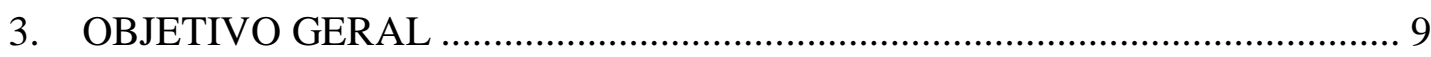

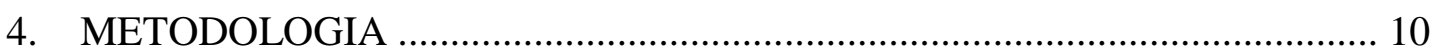

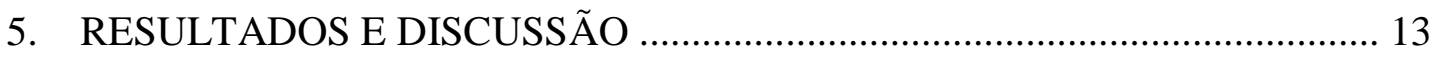

TRATAMENTO TAXONÔMICO: A SUBTRIBO ONCIDIINAE .................. 13

CHAVE PARA OS GÊNEROS DE ONCIDIINAE OCORRENTES NO

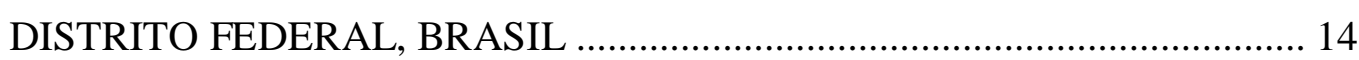

DESCRIÇÕES DE GÊNEROS E ESPÉCIES ............................................. 16

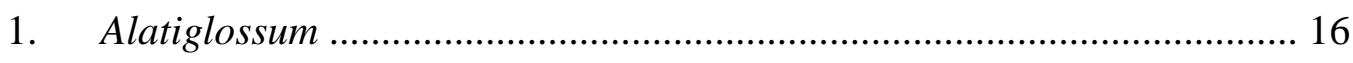

1.1. Alatiglossum fuscopetalum ................................................................. 18

1.2. Alatiglossum macropetalum ................................................................. 19

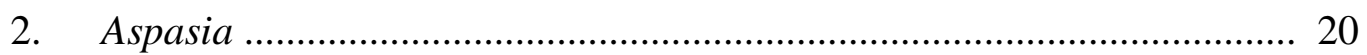

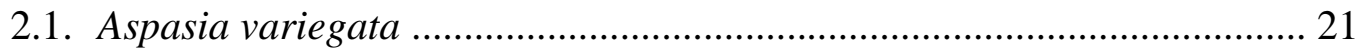

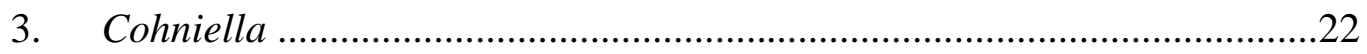

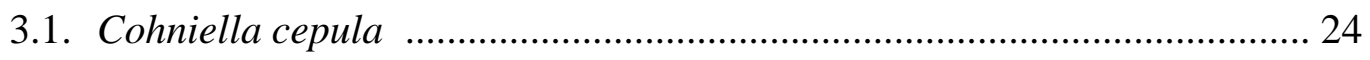

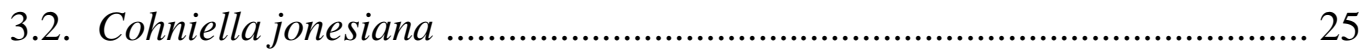

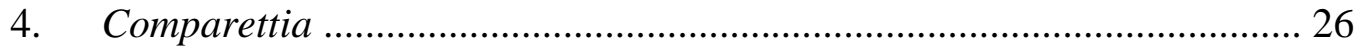

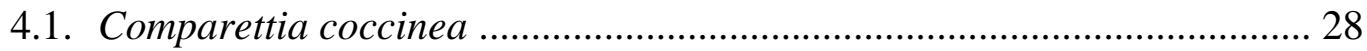

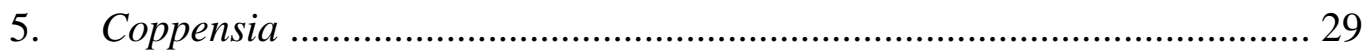

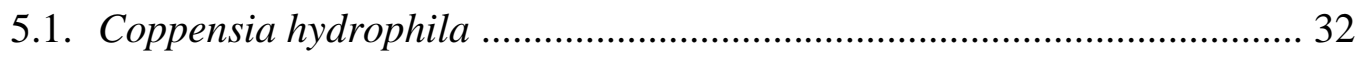

5.2. Coppensia varicosa .......................................................................... 34

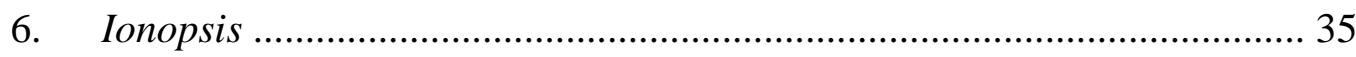




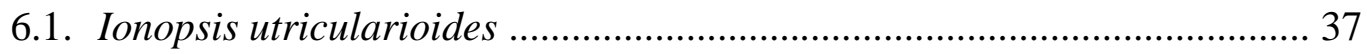

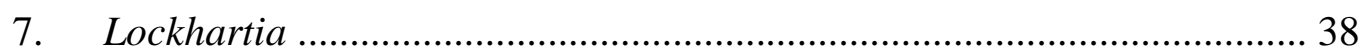

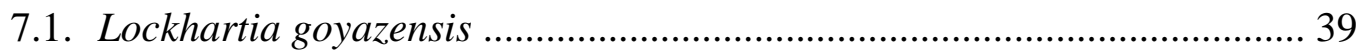

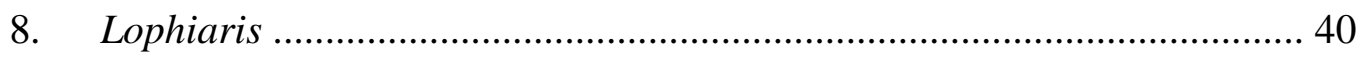

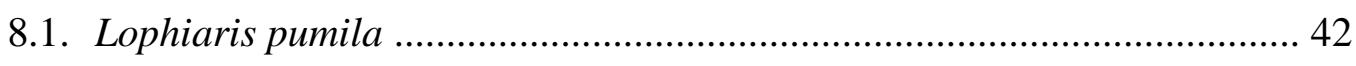

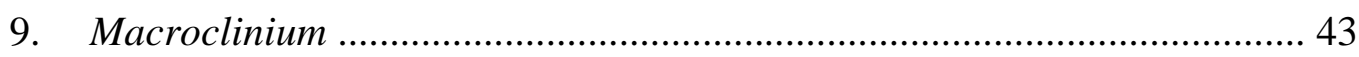

9.1. Macroclinium wullschlaegelianum .......................................................... 45

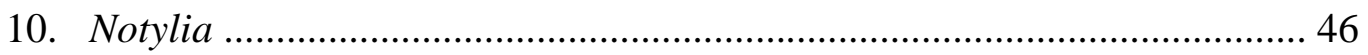

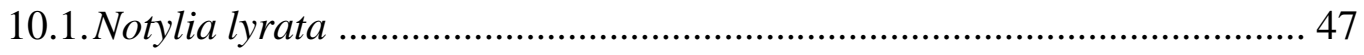

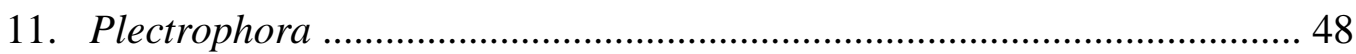

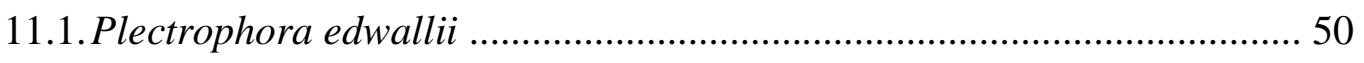

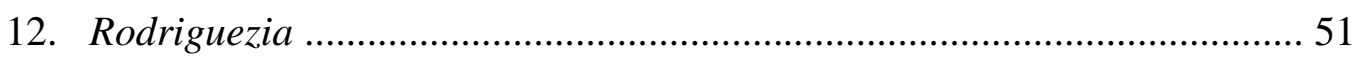

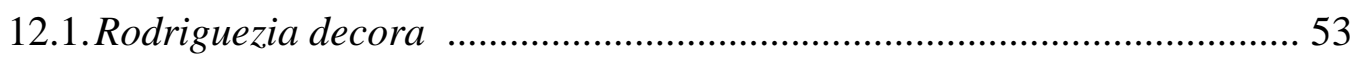

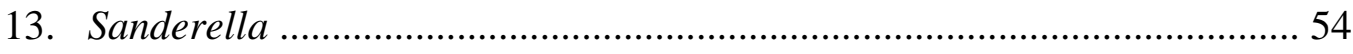

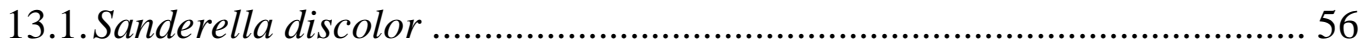

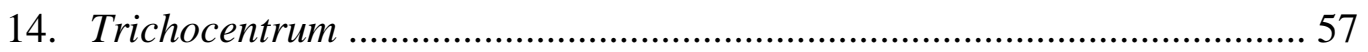

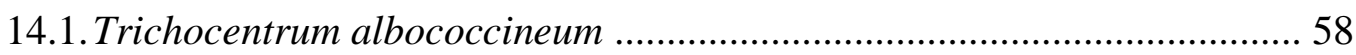

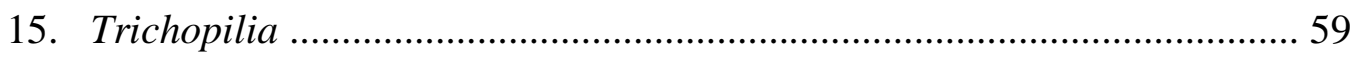

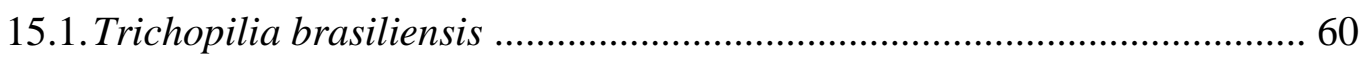

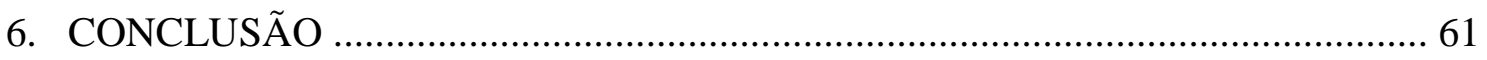

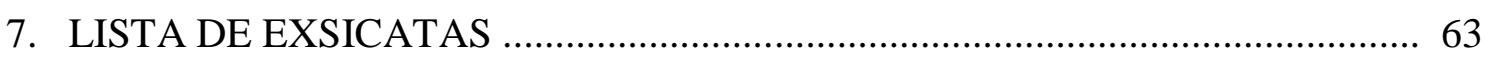

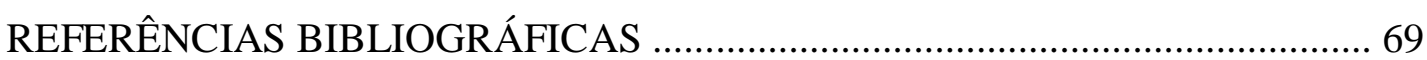

ANEXO I (Descrição do gênero e espécie) ……................................................... 79 


\section{LISTAS DE FIGURAS}

FIGURA 1. PRANCHA 64

FIGURA 2. PRANCHA 65

FIGURA 3. PRANCHA 66

FIGURA 4. Distribuição de Espécies de Oncidiinae no Distrito Federal, Brasil. Alatiglossum fuscopetalum (Hoehne) Baptista., Alatiglosum macropetalum (Lindl.) Baptista., Aspasia variegata Lindl., Cohniella cepula (Hoffmanns.) Carnevali E G. Romero, Comparettia coccinea Lindl., Coppensia hydrophila (Barb. Rodr.) Campacci, Coppensia varicosa (Lindl.) Campacci, Ionopsis utriculariodes (Sw.) Lindl., Lockhartia goyazensis Rchb.f. 67

FIGURA 5. Distribuição de Espécies de Oncidiinae no Distrito Federal, Brasil. Lophiaris pumila (Lindl.) Braem, Macroclinium wullsglaegelianum (H.Focke) Dodson, Notylia lyrata S.Moore, Plectrophora edwallii Cogn., Rodriguezia decora Rchb. f., Sanderella discolor (Barb.Rodr.) Cogn., Trichocentrum albococcinium Linden., Trichopilia brasiliensis Cogn. 68 


\section{RESUMO}

As orquídeas pertencem a uma das maiores e mais diversificadas famílias de plantas com flores do mundo. A subtribo Oncidiinae Benth. (Cymbidieae, Epidendroideae) é a segunda maior subtribo de orquídeas das Américas. Segundo a Lista de Espécies da Flora do Brasil a representatividade no Distrito Federal é de 15 gêneros e 19 espécies. O objetivo deste trabalho foi elaborar um tratamento taxonômico para esta subtribo para a "Flora do Distrito Federal, Brasil". Foram feitas saídas de campo na época de floração, foi realizado o cultivo de plantas vegetativas. Foram consultados os herbários BHCB, CEN, HEPH, IBGE, e UB, sendo o último a instituição escolhida para depósito das novas coletas. Foi realizada a análise morfológica de todo o material (116 coletas), e foi encontrado mais um gênero e duas espécies para o Distrito Federal, Cohniella jonesiana (Rchb.f.) Christenson e Trichopilia brasiliensis Cong. Foi suprimida a ocorrência de Coppensia bifolia (Sims) Dumort decorrente de uma amostra erroneamente identificada e também de Notylia hemitricha Barb. Rodr., e Rodriguezia brachystachys Rchb.f. \& Warm., por não haver nenhuma amostra ou coleta em herbários que morfologicamente se enquadre na descrição da espécie e o herbário HB que cita a amostra está fechado. Através dos estudos realizados, a lista de gêneros e espécies de Oncidiinae Benth. ocorrentes no DF foi corrigida para 15 gêneros e 18 espécies, a saber: Alatiglossum fuscopetalum (Hoehne) Baptista, Alatiglossum macropetalum (Lindl.) Baptista, Aspasia variegata Lindl., Cohniella cepula (Hoffmanns.) Carnevali \& G. Romero, Cohniella jonesiana (Rchb.f.) Christenson, Comparettia coccinea Lindl., Coppensia hydrophila (Barb.Rodr.) Campacci, Coppensia varicosa (Lindl.) Campacci, Ionopsis utricularoides (Sw.) Lindl., Lockhartia goyazensis Rchb.f., Lophiaris pumila (Lindl.) Braem, Macroclinium wullschlaegelium Focke, Notylia lyrata S.Moore, Plectrophora edwallii Cogn., Rodriguezia decora (Lem.) Rchb.f., Sanderella discolor (Barb.Rodr.) Cogn., Trichocentrum albococcineum Lindl., e Trichopilia brasiliensis Cong. Foram descritos todos os gêneros e espécies, e elaboradas chaves de identificação e ilustrações para os gêneros e para as espécies. Conclui-se que algumas espécies de Oncidiinae ocorrentes no Distrito Federal possuem ampla distribuição enquanto que outras se mostram localmente raras e exigem intenso esforço de coleta para seu registro.

Palavras-chave: Distrito Federal, Florística, Oncidiinae, Orchidaceae, Taxonomia 


\begin{abstract}
Orchids belong to one of the largest and most diverse families of flowering plants in the world. The subtribe Oncidiinae Benth. (Cymbidieae, Epidendroideae) is the second largest orchid subtribe of the Americas. According to the brazilian species link "Flora do Brasil" the representativity of the subtribe in Distrito Federal is of 15 genera and 19 species. The objective of this study was to develop a taxonomic treatment of the subtribe for "Flora do Distrito Federal, Brasil." Field trips were made during the flowering season, and also the cultivation of vegetative plants. The herbaria BHCB, CEN, HEPH, IBGE, and UB were consulted, the latter being the institution chosen for deposit of the new collections. Morphological analysis of all the material (116 samples) was made and it was registered a new occurrence of species and genus to Distrito Federal with Cohniella jonesiana (Rchb.f.) Christenson and Trichopilia brasiliensis Cong. The occurrence of Coppensia bifolia (Sims) Dumort was suppressed due to a misidentified sample. Notylia hemitricha Barb.Rodr. and Rodriguezia brachystachys Rchb.f. \& Warm. were also suppressed because there is no sample or collection in herbaria that morphologically fits the description of the species and the herbarium HB citing the sample is closed. With this study, the list of genera and species of Oncidiinae Benth. occurring in Distrito Federal was corrected to 15 genera and 18 species, namely: Alatiglossum fuscopetalum (Hoehne) Baptista, Alatiglossum macropetalum (Lindl.) Baptista, Aspasia variegata Lindl., Cohniella cepula (Hoffmanns.) Carnevali \& G. Romero, Cohniella jonesiana (Rchb.f.) Christenson, Comparettia coccinea Lindl., Coppensia hydrophila (Barb.Rodr.) Campacci, Coppensia varicosa (Lindl.) Campacci, Ionopsis utricularoides (Sw.) Lindl., Lockhartia goyazensis Rchb.f., Lophiaris pumila (Lindl.) Braem, Macroclinium wullschlaegelium Focke, Notylia lyrata S.Moore, Plectrophora edwallii Cogn., Rodriguezia decora (Lem.) Rchb.f., Sanderella discolor (Barb.Rodr.) Cogn., Trichocentrum albococcineum Lindl., e Trichopilia brasiliensis Cong. All genera and species have been described, and identification keys and illustrations for the genera and species were elaborated. We conclude that some species of Oncidiinae occurring in Distrito Federal have wide distribution while others show locally rare and require intense effort collection for registration.
\end{abstract}

Keywords: Distrito Federal, Floristics, Oncidiinae, Orchidaceae, Taxonomic 


\section{INTRODUÇÃO}

\subsection{A FAMÍLIA ORCHIDACEAE}

As orquídeas são monocotiledôneas e pertencem a uma das maiores e mais diversificadas famílias de plantas com flores do mundo (Dressler, 1981). O grupo evoluiu com adaptações altamente especializadas para atrair, enganar e manipular os insetos para a polinização, e isso tem fascinado os pesquisadores e observadores desde a época de Darwin (Dressler, 1981). Muitas espécies oferecem néctar ou óleos florais como forma de recompensa aos polinizadores, entretanto, grande parte das espécies não oferece nenhum tipo de recompensa e, por esse motivo, essas espécies conseguem a realização de polinização por meio de estratégias de "engano", com suas flores mimetizando a forma, emitindo odores característicos ou dividindo ambientes com espécies (pertencentes a outras famílias, como exemplo Malpighiaceae) que oferecem recompensa (Chase et al., 2009).

As orquídeas apresentam variações na morfologia floral e vegetativa, sendo observadas desde plantas com flores de tamanho milimétrico (por exemplo, Lophiaris pumila (Lindl.) Braem) até plantas maiores que uma pessoa (por exemplo, Grammatophyllum speciosum Blume), e flores com coloração muito atrativa até cores neutras e perfumes agradáveis a desagradáveis (Baptista et al., 2011).

A estimativa é que existam, no mundo, cerca de 25.400 espécies, divididas em cerca de 1.000 gêneros (Baptista et al., 2011). Representantes da família Orchidaceae encontram-se distribuídos em quase todas as partes do mundo, exceto nas regiões polares e deserticas extremamente áridas (Baptista et al., 2011). Com uma representação marcante nas Américas, sendo a Colômbia o país com maior número, com 4.010 espécies, seguido pelo Equador, com 3.784 espécies e pelo Brasil, com 2.459 espécies (Dodson, 2003; Sarmiento, 2007; Barros et al., 2015).

A capacidade de adaptação das orquídeas a vários tipos de vegetação se deve, entre outras causas, às diferentes estruturas vegetativas presentes na família, apresentando estratégias para a captação e reserva de água e nutrientes, entre elas, caules do tipo pseudobulbos e folhas carnosas com a função de armazenar reservas, raízes dotadas de velame com a função de rápida absorção de água e nutrientes e o 
próprio crescimento em touceiras, permitindo o acúmulo de matéria orgânica (Hoehne, 1949).

As orquídeas são plantas herbáceas e perenes e o comportamento pode variar entre epífitas (cerca de 70\%), terrestres, rupestres, trepadeiras e saprófitas (Silva, 1999).

As Orchidaceae caracterizam-se por possuir raízes fasciculadas que, em algumas espécies, são carnosas e intumescidas (tuberóide). Na grande maioria das espécies, especialmente nas epífitas, as raízes são revestidas por uma epiderme multisseriada, esponjosa e esbranquiçada, denominada velame, que possui a função de rápida absorção de água e proteção contra ressecamento. Caules secundários podem ser intumescidos em pseudobulbos com a função de armazenamento de água e nutrientes. As folhas são alternas, dísticas ou espiraladas. A prefoliação pode ser duplicada, conduplicada, plicada ou convoluta. As flores são hermafroditas, ou raramente unissexuais (dimorfas, em Catasetum Rich. ex Kunth), frequentemente zigomorfas, raramente assimétricas, geralmente trímeras, sendo uma das pétalas oposta ao estame fértil, morfologicamente modificada, constituindo o labelo. $O$ labelo pode ser concrescido com a coluna e as regiões basais e centrais apresentam-se geralmente calosas. O calo pode ser na forma de quilha, placa, ou possuir cornículos, verrugas, estruturas secretoras de óleos ou osmóforos, que emitem odores. O androceu é constituído de um, raro dois, ou três estames férteis. O filete é adnado ao estilete formando a coluna ou ginostêmio; o estigma localiza-se geralmente na face ventral do ginostêmio, é trilobado, sendo um dos lobos parcialmente estéril, formando o rostelo, que separa a antera do estigma. A antera, na maioria dos casos, é representada por um “capuz” com a finalidade de proteger o pólen e geralmente decídua na retirada do pólen. O pólen, na maioria das espécies é unido em polínias, em número de 2, 4, 6 ou 8. O ovário é ínfero, unilocular, tricarpelar, com placentação parietal. Os frutos são capsulares, geralmente secos, sendo que em alguns gêneros de epífitas podem apresentar-se como cápsulas carnosas. As sementes são numerosas, minúsculas, com embrião rudimentar, desprovidas de endosperma, adaptadas à disseminação pelo vento, fato importante para a forma de vida epífita (Weberling \& Schwantes, 1986; Silva, 1999; Chase, 2009; Baptista et al., 2011; Rodrigues, 2011).

Após estudos de filogenia com utilização de dados moleculares, e de acordo com o tipo de agregação dos grãos de pólen (características das políneas), anteras e folhas, a família Orchidaceae foi dividida em cinco subfamílias: Apostasioideae, 
Cypripedioideae, Epidendroideae, Orchidoideae, e Vanillioideae (figura 1) (Pridgeon et al., 1999).

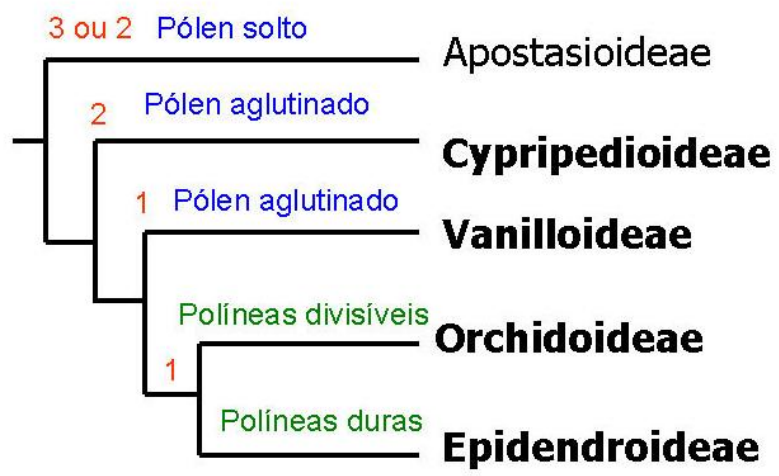

Figura 1. Relações filogenéticas entre as subfamílias de Orchidaceae (modificado de Cameron et al., 1999). As subfamílias em negrito estão representadas no Brasil.

(*) Número de anteras férteis

(*) e (*) Tipo de agregação e consistência do pólen

A subfamília a ser estudada no presente trabalho, Epidendroideae Lindley, tem quase 600 gêneros (Baptista et al., 2011). Possui grande número de espécies epífitas, e caracterizada por possuir antera terminal, 2-8 polínias rígidas, com consistência cartilaginosa, geralmente com apêndices como caudículo, estipe e viscídio (Baptista et al., 2011). O ginostêmio pode prolongar-se formando um pé da coluna, tendo a base das sépalas laterais adnadas a ele formando um mento (Rodrigues, 2011). Essa subfamília é dividida em 16 diferentes tribos (Arethuseae, Calypsoeae, Collabieae, Cymbidieae, Dendrobieae, Epidendreae, Gastrodieae, Malaxideae, Neottieae, Nervilieae, Podochileae, Sobralieae, Triphoreae, Tropidieae, Vandeae, Xerorchideae) (Baptista et al., 2011).

A tribo Cymbidieae Pfitzer apresenta o maior número de espécies, com distribuição em todos os continentes e possivelmente abarca um terço das espécies brasileiras (Baptista et al., 2011). Morfologicamente, a tribo Cymbidieae Pfitzer é caracterizada geralmente por plantas de porte médio, crescimento simpodial, presença de velame, pseudobulbos, folhas articuladas, inflorescências geralmente na base dos pseudobulbos, flores com estipe, e de duas a quatro polínias (Baptista et al., 2011). A 
tribo Cymbidieae Pfitzer apresenta nove subtribos (Baptista et al., 2011) entre as quais, a subtribo Oncidiinae Benth., objeto do presente estudo.

\subsection{A SUBTRIBO ONCIDIINAE BENTH.}

Para um melhor entendimento relacionado à nomenclatura das espécies pertencentes à subtribo Oncidiinae, se faz necessário uma rápida revisão sobre o gênero Oncidium Swartz, tipo da referida subtribo.

A taxonomia do gênero Oncidium, até pouco tempo, mostrava-se particularmente difícil, especialmente pelos critérios utilizados para a classificação das espécies bem como pelos limites genéricos imprecisos ou pouco definidos.

O gênero Oncidium foi estabelecido em 1800 por Olof Swartz e possuia cerca de 520 espécies, sendo a maioria epífitas e algumas terrestres (Senghas, 1998 apud Faria, 2004). O nome Oncidium (grego: onkidion diminutivo de onkos = tumor, nódulo, inchaço), é uma alusão ao pequeno calo que ocorre na base do labelo (Chase, 2009). Originalmente o gênero foi definido baseado em cinco espécimes que representavam 5 diferentes espécies, a saber: Oncidium altissimum (Jacq.) Sw. (originalmente descrito como Epidendrum altissimum, por Jacquin em 1760); Oncidium cebolleta (Jacq.) Sw. (originalmente descrito como Epidendrum cebolleta, por Jacquin em 1760); Oncidium carthagenense (Jacq.) Sw. (originalmente descrito como Epidendrum carthagenense, por Jacquin em 1760); Oncidium quadripetalum Sw. (originalmente descrito como Epidendrum tetrapetalum, por Jacquin em 1760) e, finalmente, Oncidium variegatum (Sw.) Sw. (originalmente descrito como Epidendrum variegatum, por Swartz em 1788) (Braem, 1993).

À época da descrição do gênero, os critérios utilizados por Swartz eram suficientes para a discriminação das espécies de Oncidium dos demais gêneros. Entretanto, com o passar dos anos, novas espécies foram descritas e, devido ao fato da circunscrição ou limites genéricos se mostrarem imprecisos ou pouco definidos, todas as espécies que "pareciam" Oncidium, mesmo aquelas que mostravam discrepâncias morfológicas, foram "acomodadas" no gênero que comportava muitas espécies. Além do grande número de espécies, algumas características apresentadas aumentavam os problemas relacionados à taxonomia, tais como: as espécies apresentavam ampla 
distribuição geográfica (Flórida, USA à Argentina); diversos comportamentos (epífitas, terrestres e rupícolas); vegetavam em ambientes diversos (áreas com alta umidade até áreas desérticas); muita variação na morfologia externa e muita variação no número cromossômico (Braem, 1993).

A primeira revisão do gênero Oncidium foi realizada por Fritz Kräenzlin (Kräenzlin, 1922) e publicado em Das Pflanzenreich. Esse trabalho foi considerado bastante impreciso e insatisfatório para a identificação de espécies, não sendo muito útil (Braem, 1993). Entre os diversos problemas do trabalho de Kräenzlin, muitas de suas ilustrações não coincidiam com as descrições das espécies (Braem, 1993; Faria, 2004) induzindo os estudiosos a erros nas identificações. Por mais de cinqüenta anos, depois do trabalho de Kräenzlin (1922), muitos autores haviam externado a necessidade de uma nova revisão do gênero, alegando que muitas espécies deveriam ser segregadas de Oncidium e colocadas em gêneros autônomos. Somente em 1974 Garay \& Stacy propõem uma nova classificação para Oncidium. Após várias ponderações os autores realizam a subdivisão de Oncidium em 26 seções delimitadas com base em caracteres florais. Nesse mesmo trabalho, Garay e Stacy (1974) também lectotipificam Oncidium variegatum como espécie tipo para o gênero, pois era a única espécie do gênero ilustrada por Swartz em sua publicação original de Oncidium. Mais tarde, em 1982, Dressler e Williams propõem a indicação de Oncidium altissimum (Jacq.) Sw. como lectótipo, proposta esta aceita pelo Committee for Spermatophyta (Stafleu, 1985). Começava a partir desse período uma nova revisão do gênero Oncidium s.l. onde todas as espécies pertencentes à seção de $O$. altissimum seriam consideradas os "verdadeiros" Oncidium. Todas as demais espécies deveriam ser "acomodadas" em outros gêneros e, portanto, deveriam receber novos nomes (Braem, 1993).

A subtribo Oncidiinae Benth. (Cymbidieae, Epidendroideae) é uma das mais diversas subtribos de Orchidaceae e é a segunda maior subtribo das Américas com uma expressiva diversidade na morfologia floral e vegetativa comportando 69 gêneros (Chase, 2009) e cerca de 1.700 espécies de distribuição exclusivamente neotropical (Penha et al., 2011). No Brasil, a representatividade da subtribo Oncidiinae Benth. é de cerca de 49 gêneros e 360 espécies (Barros et al., 2015). No Distrito Federal encontra-se representada por 15 gêneros e 19 espécies (Barros et al., 2015). 
Antes de estudos filogenéticos moleculares, a delimitação da subtribo Oncidiinae era bastante variada, desde o conceito relativamente amplo de Dressler (1993) para os conceitos relativamente estreitos de Szlachetko (1995).

Baseado apenas na morfologia, Dressler (1993) considerava as subtribos Ornithocephalinae e Telipogoninae como subtribos próximas, porém distintas de Oncidiinae. Já Whitten et al. (2000) e Chase (2009), baseados em estudos moleculares, demonstram que as subtribos Ornithocephalinae, Pachyphyllinae e Telipogoninae se encontram "embebidas" dentro de Oncidiinae e, essa nova abrangência para Oncidiinae é aceita pela maioria dos taxonomistas.

As flores da subtribo Oncidiinae possuem uma grande diversidade de forma, tamanho e função, envolvendo uma gama de polinizadores, o que as torna atraentes para estudos evolutivos (Neubig, 2012). Em relação às recompensas florais, têm-se como recursos o néctar, os óleos e as fragrâncias. Entre as estratégias de polinização, destacase o engano (de flores que não oferecem recompensa) e a mimetização dessas flores com flores que oferecem recompensas (especialmente aquelas da família Malpighiaceae) (Neubig, 2012). Neste grupo o número de cromossomos é também bastante variável, variando do menor número conhecido em orquídeas, $2 \mathrm{n}=10$, a $2 \mathrm{n}=$ 168 (Felix e Guerra, 2000; Neubig, 2012)

Alguns trabalhos propostos para Orchidaceae (Chase \& Palmer, 1989) e, mais especificamente para Oncidiinae Benth. (Chase et al., 2009), sugerem que a utilização unicamente de características florais não deve ser utilizada para a definição dos limites genéricos e para a formulação de hipóteses filogenéticas.

Os estudos filogenéticos vêm demonstrando que muitos gêneros de Oncidiinae Benth. em sua circunscrição tradicional são polifiléticos ou parafiléticos (Williams et al., 2001). Dentro de uma visão moderna, visando estabelecer a monofilia dos gêneros, é necessária uma ampliação na circunscrição de alguns gêneros, juntamente com as alterações nomenclaturais necessárias (Williams et al., 2001).

Alguma das novas propostas filogenéticas (Chase et al., 2009) para os gêneros de Oncidiinae Benth., na tentativa de se realizar arranjos monofiléticos, sugerem que espécies pertencentes a gêneros autônomos como Alatiglossum D.H. Baptista, Baptistonia Barb. Rodr., Binotia Rolfe, Carriella V.P.Castro \& K.G.Lacerda, Coppensia Dumort, Ornithophora Barb. Rodr., Rodrigueziella Kuntze e Rodrigueziopsis Schltr., entre outros, sejam transferidos para Gomesa s.l. Do mesmo 
modo, trabalhos de Williams et al. (2001), corroborado por Chase (2009), também sugerem novos arranjos, transferindo espécies pertencentes a gêneros como Cohniella Pfitzer, Lophiarella Szlach., Lophiaris Raf., entre outros, para Trichocentrum s.l. Aqui deve-se considerar que muitos autores (Sandoval-Zapotitla \& Terrazas, 2001; Sosa et al., 2001; Williams et al., 2001; Chase, 2009; Chase et al., 2009, WCSP, 2014; entre outros) aceitam as propostas realizadas por Williams et al. (2001) e Chase et al. (2009).

Discordando dos novos arranjos propostos acima, adotamos neste trabalho a Lista das espécies da Flora do Brasil (2014), embasada em Braem (1993), Pupulin (1995), Königer \& Pongratz (1997, 1999), Jiménez-Machorro \& Carnevali (2001), Pupulin \& Carnevali (2005), Carnevali et al. (2013). Estes autores reconhecem gêneros menores (Alatiglossum D.H. Baptista, Coppensia Dumort, Cohniella Pfitzer, Lophiaris Raf. e Trichocentrum Poepp. \& Endl. (s.s.), entre outros), desde que possuam suporte monofilético, justificando o reconhecimento de caracteres morfológicos e anatômicos e a facilidade em diagnosticar gêneros com uma delimitação mais estreita.

\subsection{DIVERSIDADE E DISTRIBUIÇÃO NO BRASIL}

O Brasil detém uma das maiores riquezas de orquídeas do continente americano e do mundo, com cerca de 238 gêneros e 2.553 espécies, das quais 1.636 são endêmicas, distribuídas em todas as formações vegetais brasileiras (Barros et al., 2015).

A representatividade da família Orchidaceae no território brasileiro aponta a Mata Atlântica como uma das regiões de maior diversidade em orquídeas, com 186 gêneros e 1.577 espécies, seguidos pela Floresta Amazônica, com 159 gêneros e 885 espécies. O Cerrado é o terceiro bioma em representatividade de orquídeas, com 138 gêneros e 730 espécies (Lista de Espécies da Flora do Brasil, 2015).

No Brasil, a subtribo Oncidiinae encontra-se representada por 49 gêneros e 360 espécies (Barros et al., 2015). Segundo a Lista de Espécies da Flora do Brasil os gêneros de Oncidiinae estão muito bem representados no bioma Mata Atlântica e em menor grau nos demais biomas, com baixa representatividade para o bioma Caatinga e no bioma Pampa. Encontram-se representados da seguinte forma: Mata Atlântica, 41 gêneros e 242 espécies (representatividade de 83,6\%); Amazônia, 30 gêneros e 120 
espécies (59,1\%); Cerrado, 28 gêneros e 76 espécies (57,1\%); Caatinga nove gêneros e 10 espécies (18,3\%) (Barros et al., 2015).

\subsection{DIVERSIDADE E DISTRIBUIÇÃO NO BIOMA CERRADO}

O conhecimento da flora do Cerrado cresceu muito nos últimos 20 anos. A UNESCO (2002) estimou que a flora do Cerrado teria mais de 6.000 espécies de plantas vasculares, com um grande número de espécies endêmicas. A lista de espécies da Flora do Brasil de 2015, de Angiospermas do Bioma Cerrado inclui 181 famílias, 1.673 gêneros e 12.384 espécies.

Para a flora do bioma Cerrado, Orchidaceae desponta como uma das famílias mais ricas em espécies. Desde o trabalho pioneiro de Warming (1892), posteriormente traduzido (Warming, 1973), até trabalhos recentes de levantamentos florísticos no Bioma Cerrado, Orchidaceae aparece, invariavelmente, como uma das quatro famílias numericamente mais representativas, em um universo de cerca de 171 famílias (Mendonça et al., 2008). Mendonça et al. (2008) elencaram 121 gêneros e 666 espécies para o bioma e, em 2014, são elencados 138 gêneros e 730 espécies, em decorrência de novos estudos e elaboração de listas para a flora de orquídeas do Brasil (Lista de Espécies da Flora do Brasil, 2015).

\subsection{DIVERSIDADE E DISTRIBUIÇÃO NO DISTRITO FEDERAL}

A Lista da flora do Brasil 2015 registra no Distrito Federal 156 famílias e aproximadamente 1.006 gêneros e 3.414 espécies de fanerógamas, sendo que 80 gêneros e 252 espécies pertencem à família Orchidaceae. Para o Distrito Federal, foram registrados 15 gêneros e 19 espécies pertencentes à subtribo Oncidiinae.

No Distrito Federal foram realizados trabalhos florísticos e morfológicos que geraram listas para Orchidaceae, tais como: Lista das espécies vasculares registradas na Reserva Ecológica do IBGE, dividida por grandes grupos taxonômicos e famílias e relacionando hábitos e ambientes de ocorrência (Pereira et al., 1993), Levantamento florístico da estação ecológica de Águas Emendadas (Maury et al., 1994), A vegetação 
da fazenda Sucupira (Walter \& Sampaio, 1998), Listagem e nível de proteção das espécies de fanerógamas do Distrito Federal (Proença et al., 2001), Levantamento florístico e das fisionomias do Parque Ecológico Ezechias Heringer (Parque do Guará), Distrito Federal (Nogueira et al., 2002), Lista atualizada das Orchidaceae do Distrito Federal (Batista \& Bianchetti, 2003), Estudo do gênero Oncidium (Pellizzaro et al., 2004), Orchidaceae da Reserva Ecológica do Guará, Distrito Federal (Batista et al., 2005), Família Orchidaceae na APA de Cafuringa e sua contribuição para a diversidade da flora do Distrito Federal e do bioma Cerrado (Bianchetti et al., 2005), O gênero Encyclia (Orchidaceae) no Distrito Federal, Goiás e Tocantins (Meneguzzo et al., 2012).

\section{JUSTIFICATIVA}

A Flora do Distrito Federal está sendo cada vez mais estudada, porém as orquídeas possuem poucos tratamentos genéricos de grupos específicos para a região do Distrito Federal (Batista \& Bianchetti, 2003).

Para o Distrito Federal, a subtribo Oncidiinae Benth. foi escolhida por possuir cerca de 15 gêneros e 19 espécies e não possuir um tratamento adequado, como por exemplo disponibilização de uma chave de identificação e informações sobre as espécies, dados ecológicos e habitats.

A presente dissertação tem como proposta ampliar o levantamento da Subtribo Oncidiinae Benth. no Distrito Federal, refinar o conhecimento sobre a localização, os habitats de ocorrência e, fornecer ferramentas (chave e descrição das espécies) que permitam a identificação das espécies.

\section{OBJETIVO GERAL}

- Realizar um estudo florístico clássico da subtribo Oncidiinae Benth. dentro dos moldes do Projeto Flora do Distrito Federal, com uma chave para identificação dos gêneros e das espécies pertencentes à subtribo, comentários, descrições genéricas e específicas, mapas de distribuição das espécies, e ilustrações. 


\section{METODOLOGIA}

Quanto à abordagem taxonômica utilizada no presente trabalho, concordamos com os autores supra-citados, no que diz respeito à preferência ao reconhecimento de gêneros menores, com delimitação mais estreita, com suporte monofilético e de fácil reconhecimento morfológico como, por exemplo Alatiglossum D.H. Baptista e Coppensia Dumort, ao invés de Gomesa (s.l.), e Cohniella Pfitzer, Lophiaris Raf. e Trichocentrum Poepp. \& Endl. (s.s.) ao invés de Trichocentrum (s.l). Além disso, corroboramos a mesma abordagem utilizada pela Lista de Espécies da Flora do Brasil, uma iniciativa que precisa ser reforçada e que servirá como pilar para toda a pesquisa botânica, especialmente aquela desenvolvida no Brasil.

Para o conhecimento dos dados das espécies presentes no Distrito Federal da subtribo Oncidiinae Benth., foi realizado primeiramente um levantamento nos herbários de Brasília, e INCT - Herbário Virtual da Flora e dos Fungos (2014). No levantamento foram registrados dados de etiquetas, com locais de coleta, coletores, datas e informações pertinentes. Foram consultados e analisados materiais depositados nos seguintes herbários: Empresa Brasileira de Agricultura e Pecuária - Recursos Genéticos e Biotecnologia (CEN); Herbário do Departamento de Botânica da UFMG (BHCB); Jardim Botânico de Brasília - Herbário Ezechias Paulo Heringer (HEPH); Reserva Ecológica do Instituto Brasileiro de Geografia e Estatística (IBGE); Universidade de Brasília (UB).

Em casos esporádicos em que determinadas espécies foram citadas para o Distrito Federal, porém sem apresentar registros de voucher nos herbários visitados ou voucher não visualizados (ex. Cohniella jonesiana, Gomesa foliosa e Rodriguezia brachystachys) as descrições foram realizadas a partir de material coletado fora do

Distrito Federal e, em algumas vezes, complementadas com dados a partir de bibliografia pertinente.

Para elaboração das descrições de gêneros e espécies seguiu-se uma planilha de caracteres taxonômicos importantes para a caracterização de Orchidaceae e consequente registro das características observadas (Anexo I). Para descrição dos gêneros foi utilizada bibliografia especializada onde constavam as características diagnósticas para cada gênero (Garay \& Stacy, 1974; Braem, 1993; Williams et al., 2001; Chase, 2009 (Genera Orchidacearum) e http://florabrasiliensis.cria.org.br/). As descrições genéricas 
abrangem principalmente a variabilidade morfológica total do gênero (exceto para Ionopsis) e não se detem às características apresentadas exclusivamente pelas espécies de ocorrência no Distrito Federal. A maior parte dos frutos não foi vista e as descrições foram retiradas de bibliografia pertinente (Genera Orchidacearum e http://florabrasiliensis.cria.org.br/.)

Foram elaborados comentários quanto à etimologia, distribuição geral, distribuição no bioma Cerrado e no Distrito Federal; quando possível, foram registrados dados sobre os mecanismos de polinização e prováveis polinizadores. E uma chave para os gêneros de Oncidiinae Benth. com características morfológicas marcantes do gênero. Dados sobre distribuição geográfica dos gêneros e espécies foram retirados de trabalhos específicos e especialmente da compilação de dados disponíveis nos sites (www.floradobrasil.jbrj.gov.br., www.tropicos.org. e www.apps.kew.org/wcsp.).

Foram confeccionadas 55 fichas de diagnose floral (visando compreensão e medição das peças) incluindo todos os indivíduos examinados que ainda não tivessem as referidas fichas anexadas aos vouchers. Para a confecção das fichas foi retirada uma flor de cada exsicata; foram re-hidratadas, e sob lupa, montadas em cartolina. Quando possível foi realizado desenho do labelo, valorizando a região do disco (calos) e a coluna, para melhor compreensão dessas estruturas e morfologia.

As medidas morfológicas, tanto da parte vegetativa quanto da reprodutiva (exceto das diagnoses florais), foram realizadas com régua e anotadas em planilha, para descrição. A identificação do material coletado e do material já depositado em herbários, sem identificação, foi realizada com base nas obras de Garay \& Stacy (1974), Silva (1999), Pellizzaro et al. (2004), Chase et al. (2009), e Baptista et al. (2011) bem como por comparação com material identificado por especialistas na família. Sempre que possível foi realizada a análise de materiais-tipo solicitados por meio de fototipos disponibilizados em herbários “on-line”. Foram enviadas solicitação de empréstimo de materiais de outros herbários, BHCB, de Belo Horizonte e Herbário Mello Leitão MBML-Herbário do Espírito Santo via solicitação do herbário UB, sendo recebido apenas o material de BHCB.

Para cada espécie analisada foi realizada uma descrição ampla e detalhada, nos moldes do Projeto Flora do Distrito Federal, bem como ilustração, e compilação de informações sobre habitat, ocorrência da planta e fenologia, a partir dos dados nos rótulos das exsicatas. 
Para a elaboração das chaves de identificação, os caracteres diferenciais entre gêneros e espécies foram tabelados e analisados quanto à variabilidade e facilidade de interpretação.

Foi feito levantamento bibliográfico a respeito das Orchidaceae, especialmente da subtribo Oncidiinae Benth., em trabalhos científicos na forma de teses, dissertações, periódicos, livros e sites científicos, visando o acompanhamento e evolução do conhecimento sobre o grupo, com ênfase em taxonomia e filogenia.

Também foram realizadas coletas a campo. Após o levantamento, foi detectada a presença de muitas coletas de Oncidiinae Benth., e por essa razão foi diminuída a intensidade de coletas previstas anteriormente citadas no projeto. Com isso, foram realizadas nove saídas de campo. Para as coletas em campo, foi utilizado podão para espécies epífitas localizadas acima de 2 metros de altura; para as demais foi utilizada tesoura de poda.

A primeira expedição, realizada em outubro de 2013, para o Jardim Botânico de Brasília (Mata do Cristo Redentor), resultou na observação de 10 espécies da família. Entretanto, nenhuma fazia parte da subtribo Oncidiinae. A segunda expedição foi na Reserva do IBGE (Ponte Corujão, e Mata Boca d'Água), resultando na observação de oito espécies da família e uma pertencia à subtribo Oncidiinae Notylia lyrata S.Moore sem flor. Foi realizada uma terceira expedição no Parque Nacional de Brasília, na Mata do Córrego do Acampamento, onde foram observadas 15 espécies da família. Destas, duas pertenciam à subtribo Oncidiinae (já citadas para o Distrito Federal), Notylia lyrata S.Moore e Rodriguezia decora (Lem.) Rchb.f. Foram realizadas várias saídas ao campo, sendo locais como a Fazenda dois irmãos (APA DE CAFURINGA), e observados espécies que pertencem a Orchidaceae, porém nenhum representante da subtribo foi encontrado. Foi realizada ainda uma saída de Campo na DF-100, divisa do Goiás/ Distrito Federal, porém nas matas de galeria não foram encontradas espécies de Oncidiinae. Foi realizada saída ao campo para a FERCAL e no local de mata seca decídua foi coletada uma amostra de Cohniella sp., sem flor, e em mata de galeria antropizada foi coletada Lockhartia goyazensis Rchb.f. com frutos. A última saída de campo foi realizada fora do Distrito Federal, em Formosa, no Salto de Itiquira, onde observamos muitas orquídeas e coletamos Alatiglossum sp., Cohniella sp., Plectrophora edwallii Cogn. As plantas que foram coletadas sem flor e foram depositadas em viveiro para a futura floração e identificação. Após a floração, foi realizada a herborização 
seguindo a metodologia tradicional (Walter \& Cavalcanti, 2005) e, após a identificação, os vouchers foram incorporados ao Herbário da Universidade de Brasília (UB) e as duplicatas encaminhadas para o Herbário da Embrapa CENARGEN (CEN).

\section{RESULTADOS E DISCUSSÃO}

Com o presente trabalho foi registrado mais um gênero e duas espécies (Cohniella jonesiana (Rchb. f.) Christenson. e Trichopilia brasiliensis Cogn.), atualizando a lista de espécies da Flora do Brasil com 15 gêneros e 18 espécies, pertencentes à subtribo Oncidiinae, no Distrito Federal.

Uma importante contribuição ao conhecimento da família Orchidaceae no Distrito Federal foi feita durante a coleta do Parque Nacional de Brasília, em que foram encontrados três indivíduos pertencentes à espécie Eurystyles actinosophila (Barb.Rodr.) Schltr. foram coletados. Embora esta espécie não pertença à subtribo Oncidiinae, registra-se como nova ocorrência para o Distrito Federal e para o bioma Cerrado.

\section{TRATAMENTO TAXONÔMICO}

SUBTRIBO ONCIDIINAE Benth. J. Linn. Soc., Bot., 18, 288. (1881).

Ervas geralmente epífitas, menos frequentemente terrestres, crescimento simpodial. Pseudobulbos heteroblásticos, base geralmente protegida por bainhas desenvolvidas com ou sem limbos, encimados por 1-3 folhas. Folhas dísticas, apicais, geralmente conduplicadas, bilaterais a unilaterais, às vezes cilíndricas ou terete ou lateralmente achatadas, geralmente articuladas. Inflorescência geralmente lateral (raramente terminal), simples a ramificada, 1 a multiflora, geralmente protegida por bainha. Flores geralmente ressupinadas, diminutas a grandes (no máximo de $10 \mathrm{~cm}$ de diâmetro).

Sépalas geralmente livres, em alguns casos sépalas laterais sinsépalas e, ocasionalmente, formando esporão. Pétalas geralmente livres, raramente adnadas a base da coluna. Labelo geralmente livre, geralmente sem nectário, algumas vezes com esporão nectarífico, calo muitas vezes produzindo óleo, com morfologia complexa. 
Coluna ereta, geralmente alongada, muitas vezes com asas ou outros apêndices, às vezes na base apresentando tecido semelhante ao calo do labelo (tábula infraestigmática), raramente com base projetada formando um pé da coluna; clinândrio geralmente liso, em alguns casos muito desenvolvido, lacerado; antera terminal, operculada; polinário formado por 2-4 polínias, compactas e rígidas, viscídio presente; estigma ventral, inteiro ou bilobado, geralmente próximo ao ápice da coluna; rostelo frequentemente afilado, às vezes alongado. Ovário glabro, raramente equinado. Cápsula 3-(6) rimosa.

\section{CHAVE PARA OS GÊNEROS DE ONCIDIINAE OCORRENTES NO DISTRITO FEDERAL, BRASIL}

1 - Folhas equitantes, não articuladas Lockhartia (pg. 40) (L. goyazensis fig. 2. A-B)

1' - Folhas com morfologia diversa, articuladas 2

2 - Folhas teretes Cohniella (pg. 22)

2' - Folhas ensiformes, flabeliformes ou conduplicadas porém nunca teretes 3

3 - Folhas ensiformes ou flabeliformes 4

3' - Folhas conduplicadas de outras maneiras 5

4 - Inflorescência uniflora; flores com esporão Plectrophora (pg. 51) (P. edwallii fig. 2. C-D) 4' - Inflorescência multiflora; flores sem esporão Macroclinium (pg. 46) (M. wullsclaegelianum fig. 2. E-F)

5 - Folhas carnosas, geralmente pintalgadas de roxo 6 5' - Folhas coriáceas, sem pintas 7 
6 - Flores com esporão; coluna não alada, com braços apicais desenvolvidos

Trichocentrum (pg. 60)

(T. albococcineum e fig. 3. G-H)

6' - Flores sem esporão; coluna alada, sem braços apicais Lophiaris (pg. 42)

(L. pumila)

7 - Labelo inserido na metade da coluna Aspasia (pg. 20)

(A. variegata fig. $1 . \mathrm{G}-\mathrm{H})$

7' - Labelo inserido na base da coluna 8

8 - Sépalas laterais completamente fundidas formando esporão

Comparettia (pg. 26)

(C. coccinea fig. 1. C-D)

8' - Sépalas laterais livres ou parcialmente fundidas, sem esporão ou formando pequeno mento 9

9 - Clinândrio muito desenvolvido (acima da antera), lacerado Trichopilia (pg. 62)

(T. brasiliensis fig. 3. D)

9' - Clinândrio pouco ou não desenvolvido, liso ou inteiro 10

10 - Coluna com asas ou estelídios desenvolvidos ladeando o estigma; presença de tábula infraestigmática

10’ - Coluna sem asas ou estelídios; ausência de tábula infraestigmática 12

11 - Pétalas mais largas e mais longas que as sépalas Alatiglossum (pg. 16)

$11^{\prime}$ - Pétalas de tamanho similar às sépalas Coppensia (pg. 29)

12 - Labelo obovado, oblanceolado, oblongo, oval, ápice geralmente emarginado _ 13 12' - Labelo hastado, ápice agudo, não emarginado Notylia (pg. 48)

(N. lyrata fig. 2. G) 
13 - Labelo obovado, oblanceolado; ápice muito dilatado em relação à base, emarginado 14 13' - Labelo oblongo a pandurado; ápice não dilatado em relação à base, não emarginado Sanderella (pg. 58)

(S. discollor)

14 - Inflorescência tipo panícula; pseudobulbos inconspícuos; rizomas curtos entre os caules secundários Ionopsis (pg. 37)

(I. utricularioides fig. 3. E-F)

14' - Inflorescência tipo racemo; pseudobulbos conspícuos; rizomas curtos a extremamente longos entre os caules secundários Rodriguezia (pg. 54)

\section{DESCRIÇÕES DE GÊNEROS E ESPÉCIES}

1. Alatiglossum Baptista, Colet. Orq. Bras. 2006.

Ervas epífitas. Rizoma curto entre os caules secundários. Caules secundários intumescidos em pseudobulbos, fusiformes a ovais, às vezes tetragonais, geralmente sulcados e ancipitados, parcialmente recobertos por bainhas foliares, encimados por 1-2 folhas. Folhas conduplicadas, bifaciais, coriáceas, articuladas, verdes. Inflorescência lateral, tipo racemo ou panícula, comprimento maior que as folhas, multiflora. Flores ressupinadas, explanadas e vistosas, geralmente amarelas e ocasionalmente com marcas marrons ou vermelhas. Sépala dorsal livre; sépalas laterais parcialmente fundidas. Pétalas livres, geralmente maiores, mais largas e de coloração diferente das sépalas. Labelo trilobado, ecalcarado, base do labelo inserido perpendicularmente na base da coluna, lobos laterais auriculados; região do disco com calo bastante verrucoso; margens do disco e istmo geralmente denteadas ou fimbriadas. Coluna com asas semicirculares ou estelídios ladeando o estigma; presença de proeminente tábula infraestigmática na base, geralmente composta por duas lamelas, ocasionalmente um sulco; clinândrio pouco desenvolvido, liso. Fruto cápsula cilíndrico-fusiforme, não a levemente 3-angulada; frutos maduros com ápice dos carpelos unidos. 
Gênero estabelecido pelo botânico brasileiro Dalton Holland Baptista, em 2006, em alusão aos lobos laterais do labelo, semelhantes a asas (Docha Neto, 2006).

O gênero possui cerca de 16 espécies, distribuídas na Argentina, Bolívia e no Brasil (Docha Neto, 2006). No Brasil ocorrem 14 espécies (11 endêmicas) nos biomas Mata Atlântica, Cerrado e em regiões semi-áridas do nordeste (Docha Neto, 2006). No bioma Cerrado ocorrem cinco espécies e dessas, duas ocorrem no Distrito Federal (Alatiglossum fuscopetalum (Hoehne) Baptista e Alatiglossum macropetalum (Lindl.) Baptista) (Barros et al., 2015).

Não existem informações sobre mecanismos de polinização e de polinizadores para espécies de Alatiglossum. Entretanto, a morfologia floral, especialmente a morfologia do calo indicam pertencerem ao grupo de Oncidiinae com flores que produzem óleos e, provavelmente, sejam polinizadas por abelhas coletoras de óleos, similares a certas espécies de Oncidium que exibem essa síndrome.

\section{Bibliografia:}

Barros, F. de; Vinhos, F.; Rodrigues, V.T.; Barberena, F.F.V.A.; Fraga, C.N.; Pessoa, E.M.; Forster, W.; Menini Neto, L. 2015 Orchidaceae. In: Lista de Espécies da Flora do Brasil. Jardim Botânico do Rio de Janeiro. http://floradobrasil.jbrj.gov.br/jabot/floradobrasil/FB19976 <acesso em: 24/02/2015>

Docha Neto, A. \& Benelli, A.P. 2006. Alatiglossum culuenense: uma nova espécie de Orchidaceae de Mato Grosso, Brasil. Orchidstudium 5:55-77.

\section{CHAVE PARA AS ESPÉCIES DE ALATIGLOSSUM NO DISTRITO FEDERAL}

1. Pétalas similares às sépalas, ápice obtuso, amarelas e densamente pintagaldas a totalmente marrons 1. A. fuscopetalum

1. Pétalas maiores que as sépalas, ápice emarginado, totalmente amarelas ou pintalgadas de marrom apenas na base 2. A. macropetalum 
1.1. Alatiglossum fuscopetalum (Hoehne) Baptista. Colet. Orquídeas Brasil. 3: 88 (2006).

Fig. 4. A

Pseudobulbos amarelo-esverdeados, 2,0-5,0 x 0,7-1,8 cm, bainhas persistentes, articuladas, 6,8-7,5 cm de compr., encimados por 1 folha. Folhas sésseis, elípticas, base atenuada, ápice agudo, 7,0-17,7 x 0,7-1,6 cm. Inflorescência paniculada, 4-11 flores, 30,0-64,0 cm de comp. total. Flores pediceladas, pedicelos 0,8-2,1 cm de comp. Sépalas similares, bases atenuadas, margens sinuadas, ápices obtusos a acuminados, membranáceas, marrom-amareladas, densamente pintalgadas de marrom escuro, sépala dorsal obovada, 0,6-0,9 x 0,2-0,5 cm, sépalas laterais $1 \backslash 3$ adnatas, elípticas, 0,8-1,3 x 0,2-0,4 cm. Pétalas obovadas a largamente elípticas, base levemente angustada, margem pouco sinuada, ápice obtuso, mucronado, membranáceas, densa a totalmente pintalgadas de marrom escuro, 0,8-1,1 x 0,6-0,8 cm. Labelo amarelo com a região central da calosidade pontilhada de marrom claro, 1,4-1,8 x 1,2-1,8 cm; lobos laterais elípticos a ovais, amarelos, 2,0-4,0 x 4,0-5,0 mm; lobo mediano oval, margem levemente erosa, emarginado, 0,8-1,1 x 1,2-1,8 cm; istmo 4,0 mm, amarelo; região do disco com calo complexo, parte basal formada por placa com protuberâncias verrucosas fundidas, parte mediana formado por lamela bífida, parte inferior da lamela com protuberâncias laterais. Coluna 2,0-3,0 x 1,0 mm, castanha, tabula infraestigmática 1,0 x 1,0 mm, asas ou estelídios amarelos 2,0 x 1,0 mm. Fruto não visto.

Alatiglossum fuscopetalum ocorre na Bolívia, Paraguai e Brasil (Tropicos, 2014; WCSP, 2014). No Brasil se distribui no Distrito Federal e nos estados de Goiás, Maranhão, Mato Grosso, Pará e Tocantins, nas regiões Centro-Oeste, Nordeste e Norte e nos biomas Amazônia e Cerrado. Vegeta em Mata Ciliar ou Mata de Galeria, Mata Seca Decídua e Mata Seca Semidecídua (Barros et al., 2015). No Distrito Federal vegeta em matas mesofíticas (Mata Seca Decídua) com afloramento calcário e floresce nos meses de Julho e Agosto.

Material selecionado: APA de Cafuringa, $15^{\circ} 33^{\prime} \mathrm{S}, 48^{\circ} 06^{\prime} \mathrm{O}$, VIII.2002, Miranda, Z.J.G. 82 (UB). FERCAL, 6,7 km da Fábrica de cimento CIPLAN, VII.1990, Bianchetti, L. 869-B (CEN). 
Material adicional examinado: GOIÁS. Niquelândia, Futuro reservatório do AHE Serra da Mesa, VII.1997, Walter, B.M.T. 3774 (CEN).

1.2. Alatiglossum macropetalum (Lindl.) Baptista. Colet. Orquídeas Brasil. 3: 88. (2006).

Fig. 4. A

Pseudobulbos amarelo-esverdeados, 1,5-4,5 x 0,7-2,1 cm, bainhas persistentes, articuladas, 2,0-9,7 cm de comp., encimados por 1 folha. Folhas sésseis, elípticas, ápice agudo, base atenuada, 2,2-17,5 x 0,5-1,8 cm. Inflorescência paniculada, 8-50 flores, 27,0-76,7 cm de comp. total. Flores pediceladas, pedicelos 1,0-1,9 cm de comp. Sépalas similares, bases atenuadas, margens levemente sinuadas, ápices agudos, membranáceas, amarelas, densamente pintalgadas de marrom, sépala dorsal obovada, 6,0-7,0 x 2,0-3,0 mm; sépalas laterais (1\3) adnatas, elípticas, 8,0-9,0 x 2,0-3,0 mm. Pétalas obovadas, base breve angustada, margens inteiras, ápice emarginado, membranáceas, totalmente amarelas ou pintalgadas de marrom apenas na base, 1,0-1,4 x 1,0-1,2 cm. Labelo amarelo com região central da calosidade com manchas marrom claro, 1,2-1,6 x 1,2-1,6 cm; lobos laterais elípticos a ovais, amarelos, 2,0-4,0 x 2,0-5,0 mm; lobo mediano ovado, margem levemente erosa, retuso a emarginado, amarelo, 0,70,9 x 1,2-1,6 cm; istmo 2,0-4,0 cm; região do disco com calo complexo envolvendo diversas protuberâncias verrucosas e lamelas. Coluna 3,0 x 1,0-2,0 mm, amarronzada, tábula infraestigmática 1,0-2,0 x 1,0-2,0 mm, asas ou estelídios amarelos 1,0 x 1,0 mm. Fruto não visto.

Alatiglossum macropetalum (Lindl.) Baptista ocorre na Bolívia e Brasil (Tropicos, 2014). No Brasil se distribui no Distrito Federal e nos estados de Goiás, Maranhão, Mato Grosso, Mato Grosso do Sul, Minas Gerais, Pará, São Paulo e Tocantins, nas regiões Centro-Oeste, Nordeste, Norte e Sudeste, nos bioma Cerrado e Mata Atlântica. Vegeta em Mata Ciliar ou Mata de Galeria, Mata Seca Semidecídua, Floresta Ombrófila (= Floresta Pluvial) (Barros et al., 2015). No Distrito Federal vegeta em Mata Ciliar e em Mata Seca Semidecídua, com floração nos meses de Julho e Agosto. 
Material selecionado: APA de Cafuringa, Próximo a comunidade do Córrego do Ouro, VIII.2003, Pellizzaro, K.F. et al., 27 (CEN). FERCAL, 6,7 km da fábrica de cimento CIPLAN, VII.1990, Bianchetti, L. 869 (CEN). Lajinha, Estrada de Sobradinho, VII.1965, Sucre, D. 647 (UB).

Material adicional examinado: MINAS GERAIS. Unaí, Cerca de $1 \mathrm{~km}$ a Jusante do Vertedouro, VII.2003, Santos, A.A. 2056 (CEN).

2. Aspasia Lindl., Gen. Spec. Orch. Pl., 139 (1833).

Ervas epífitas. Rizoma curto entre os caules secundários. Caules secundários intumescidos em pseudobulbos, ovais, ancipitados, parcialmente recobertos por brácteas, encimados por 1-2 folhas. Folhas conduplicadas, bifaciais, coriáceas, articuladas, verdes. Inflorescência lateral, tipo racemo, mais curta que o comprimento das folhas, 1-6 flores. Flores ressupinadas, vistosas, cor creme com manchas rosas ou marrom mais escuras. Sépalas e pétalas livres e similares na forma e tamanho. Labelo trilobado, panduriforme, ecalcarado, inserido na parte mediana da coluna, formando uma cavidade (pseudo nectário), lóbulos laterais tão amplos quanto o mediano; região do disco com calo composto por duas nervuras paralelas engrossadas. Coluna não alada, reta; ausência de tábula infraestigmática; clinândrio pouco desenvolvido, liso. Fruto cápsula elíptica a ovóide, não a levemente 3-angulada; frutos maduros com ápice dos carpelos unidos.

Gênero estabelecido pelo botânico inglês John Lindley, em 1833, que na Obra princeps não descreveu o significado do nome Aspasia, porém na obra de Chase (2009) é feita referência à Aspasia, a bela e alegre mulher de Péricles.

O gênero possui sete espécies que se distribuem na Guatemala, Belize, Panamá, Venezuela, Colômbia, Paraguai, Equador, Peru e Brasil (Chase, 2009). No Brasil ocorrem cinco espécies nos biomas Amazônia, Cerrado e Mata Atlântica. No bioma Cerrado está representado por apenas uma espécie, Aspasia variegata Lindl., que está presente no Distrito Federal (Barros et al., 2015).

As espécies de Aspasia possuem um labelo plano com a base adnada à coluna em ângulo reto, formando um falso nectário. São polinizadas por machos de abelhas 
Euglossini utilizando, provavelmente, estratégias de engano (ausência de néctar) ou por abelhas coletoras de fragrância, dependendo da espécie (Zimmerman \& Aide, 1987).

\section{Bibliografia:}

Barros, F. de; Vinhos, F.; Rodrigues, V.T.; Barberena, F.F.V.A.; Fraga, C.N.; Pessoa, E.M.; Forster, W.; Menini Neto, L. 2015 Orchidaceae. In: Lista de Espécies da Flora do Brasil. Jardim Botânico do Rio de Janeiro. http://floradobrasil.jbrj.gov.br/jabot/floradobrasil/FB19976 <acesso em: 24/02/2015>

Chase, M.W. 2009. Subtribe Oncidiinae. Pag. 211-391. In: Pridgeon, A.M.; Cribb, P.J.; Chase, M.W. \& Rasmussen, F.N. Genera Orchidacearum. Epidendroideae (Part Two). V. 5. Oxford. University Press.

Zimmerman JK, Aide TM. 1987. Patterns of flower and fruit production in the orchid Aspasia principissa Rchb.f. American Journal of Botany 74: 661-661.

2.1. Aspasia variegata Lindl. Edwards's Botanical Register 22: t. 1907. (1836).

Fig. 1. G-H; 4. B.

Pseudobulbos verde claros, 3,3-7,7 x 1,4-1,8 cm, protegidos por 2-3 bainhas persistentes, articuladas, 11,5-19,1 cm de compr. e bainhas paleáceas, Folhas sésseis, estreitamente elípticas a oblanceolada, base atenuada, ápice agudo, 10,2-24,0 x 1,3-3,5 cm. Inflorescência 2-4 flores, 5,0-9,5 cm de comp. total. Flores pediceladas, pedicelos 0,7-1,1 cm de comp. Sépalas similares, elípticas-obovadas, base atenuadas, margens inteiras, ápice agudo-apiculados, membranáceas, amarelas com listas violáceas, 1,9-2,0 x 0,4-0,7 cm. Pétalas mais obovadas que as sépalas, base atenuadas, margens inteiras, ápice agudos, membranáceas, amarelas com listas violáceas, 1,7-2,0 x 0,7-0,8 cm. Labelo amarelo com listas violáceas, 1,5-1,6 x 1,8-2,0 cm; lobos laterais ovalados, amarelos com listas violáceas, 0,5-0,6 x 0,9-1,0 cm; lobo mediano ovalsubquadrangular, margem sinuada, ápice emarginado, 0,9-1,0 x 1,2-1,6 cm; região do disco bicaloso, calos lineares. Coluna 1,4-1,6 cm, castanha. Fruto não visto. 
Aspasia variegata ocorre na América do Sul, incluindo a Bolívia, Colômbia, Guiana Francesa, Suriname, Trinidade, Venezuela e Brasil (Williams, 1974). No Brasil se distribui no Distrito Federal e nos estados do Amapá, Amazonas, Goiás, Maranhão, Mato Grosso, Pará, Rondônia, Roraima e Tocantins, nas regiões Centro-Oeste, Nordeste e Norte, e nos biomas Amazônia e Cerrado. Vegeta em Campinarana, Mata Ciliar ou Mata de Galeria, Floresta de Igapó, Floresta de Terra Firme, Floresta de Várzea, Mata Seca Decídua, Mata Seca Semidecídua (Barros et al., 2015). No Distrito Federal vegeta em Mata mesofítica (Mata Seca Decídua) com floração no mês de outubro.

Material examinado: DF-205, Fazenda Acre, região da Fercal, X.1999, Augusto, M.M. 1 (CEN).

Material adicional examinado: MINAS GERAIS. Unaí, Mata ao lado do túnel de fuga, II.2002, Santos, A.A. 1618 (CEN).

3. Cohniella Pfitzer, Nat. Pflanzenfam. 2, 6: 194. 1889.

Ervas epífitas ou rupícolas. Rizoma curto entre os caules secundários. Caules secundários intumescidos em pseudobulbos, pequenos (em relação ao comprimento da folha), suborbicular, protegidos por bainhas escariosas (finas, secas e membranáceas), encimados por uma folha. Folhas teretes, unifaciais, carnosas, articuladas, muitas vezes verde com pontuações roxas ou vermelhas. Inflorescência lateral, geralmente paniculada, raramente racemosa, comprimento maior que as folhas, pouco a multiflora. Flores ressupinadas, vistosas, geralmente amarelas e brancas pintalgadas de marrom. Sépalas e pétalas livres e similares, geralmente verdes ou amarelas com pontos ou manchas vermelhas ou marrons. Labelo trilobado, ecalcarado, base do labelo inserido perpendicularmente na base da coluna, lobo apical geralmente muito maior que os laterais; região do disco com calo composto por séries de placas e/ou dentes. Coluna relativamente curta, com asas semi-circulares ou estelídios ladeando o estigma; presença de proeminente tábula infra-estigmática na base; clinândrio pouco desenvolvido, liso. Fruto cápsula elipsóide a suborbicular, não a levemente 3-angulada; frutos maduros com ápice dos carpelos unidos. 
Gênero estabelecido pelo botânico alemão Ernest Hugo H. Pfitzer, em 1889, em alusão à semelhança com a espécie Cohnia quekettiodes Rcchb.f. (1852) (Fernández-Concha, 2010).

O gênero possui cerca de 17 espécies (conhecidas como "rat-tail oncidiums" ou Oncidium rabo de rato, devido à morfologia das folhas), amplamente distribuídas desde o norte do México ao norte da Argentina e Brasil (Cetzal Ix et al., 2012). No Brasil ocorrem cinco espécies em quase todos os biomas, exceto no bioma Pampa (Cetzal Ix et al., 2012). No bioma Cerrado estão representadas duas espécies, Cohniella cepula (Hoffmanns.) Carnevali \& G. Romero e Cohniella jonesiana (Rchb.f.) Christenson, que também ocorrem no Distrito Federal (Barros et al., 2015).

As espécies de Cohniella geralmente possuem flores amarelas e algumas brancas, com manchas marrons e oferecem óleos e resinas como recompensas e são visitadas por abelhas dos gêneros Centris e Paratetrapedia (Silvera, 2002 - unpublished - apud Neubig et al., 2012) e também polinizadas por abelhas do gênero Trigona (ParraTabla et al., 2000). Algumas espécies não oferecem nenhum tipo de recompensa e, provavelmente, são polinizadas por engano.

\section{Bibliografia:}

Barros, F. de; Vinhos, F.; Rodrigues, V.T.; Barberena, F.F.V.A.; Fraga, C.N.; Pessoa, E.M.; Forster, W.; Menini Neto, L. 2015 Orchidaceae. In: Lista de Espécies da Flora do Brasil. Jardim Botânico do Rio de Janeiro. http://floradobrasil.jbrj.gov.br/jabot/floradobrasil/FB19976 <acesso em: 24/02/2015>

Cetzal Ix, W.R.C.; Fernández-Concha, G.C.; Castro, V.P. 2012. Cohniella (Orchidaceae: Oncidiinae) South of the Amazon River. Systematic Botany, 37(1):5877.

Fernández-Concha, G.C., Cetzal Ix, W.R.C., Narváez, R.B., \& Romero-González, G.A. 2010. A synopsis of Cohniella (Orchidaceae, Oncidiinae). Brittonia 62(2), P.: 153-177.

Neubig, K.M., W. M. Whitten, N. H. Williams, M. A. Blanco, L. Endara, J. G. Burleigh, K. Silvera, J. C. Cushman, \& M. W. Chase. 2012. Generic recircumscriptions 
of Oncidiinae (Orchidaceae: Cymbidieae) based on maximum likelihood analysis of combined DNA datasets. Botanical Journal of the Linnean Society 168: 117-146.

Parra-Tabla V, Vargas CF, Magana-Rueda S, Navarro J. 2000. Female and male pollination success of Oncidium ascendens Lindey (Orchidaceae) in two contrasting habitat patches: forest vs agricultural field. Biological Conservation 94: 335-340.

Silvera K. 2002. Adaptive radiation of oil-reward compounds among neotropical orchid species (Oncidiinae). Unpublished M.S. thesis, University of Florida.

\section{CHAVE PARA AS ESPÉCIES DE COHNIELLA PARA O DISTRITO FEDERAL}

2. Folhas geralmente eretas; sépalas e pétalas geralmente de comprimento menor que o labelo (pétalas e sépalas $=0,6-1,5 \mathrm{~cm}$; labelo $=1,3-1,6 \mathrm{~cm}$ ); labelo amarelo; calo do labelo tridentado 1. C. cepula

1. Folhas sempre pendentes; sépalas e pétalas geralmente do mesmo comprimento ou pouco menores que o labelo (pétalas e sépalas = 1,6-2,5 cm; labelo = 2,0-2,2 cm); labelo branco; calo do labelo pentadentado

2. C. jonesiana

3.1. Cohniella cepula (Hoffmanns.) Carnevali \& G.A. Romero. Brittonia 62(2): 167 (2010).

Fig. 1. A-B; 4. B.

Pseudobulbos verdes, 0,5-0,7 x 0,3-0,7 cm, protegidos por bainhas paleáceas persistentes, pequenas. Folhas sésseis, estreito-lineares, bases truncadas, ápices agudos, suculentas, verdes, 2,5-17,5 x 0,2-1,0 cm. Inflorescência paniculada, 10-25 flores, 32,0-72,5 cm de comp. total. Flores pediceladas, pedicelos, 0,9-1,6 cm de comp. Sépalas similares, romboides a largo-elípticas, bases atenuadas, margens inteiras, ápices obtusos, membranáceas, amareladas densamente pintalgadas de marrom avermelhado, sépala dorsal, 0,6-1,0 x 0,3-0,7 cm; sépalas laterais livres, 0,8-1,5 x 0,4-0,7 cm. Pétalas obovadas, bases atenuadas, margens levemente onduladas, ápices obtusos, membranáceas, amareladas, densamente pintalgadas de marrom-avermelhado, 0,6-0,9 x 
0,3-0,6 cm. Labelo trilobado, amarelo, 1,3-1,6 x 1,1-1,7 cm; lobos laterais obovados a triangulares, no mesmo plano do lobo mediano, amarelos, 2,0-5,0 x 4,0-7,0 mm; lobo mediano oboval a espatulado, margem pouco erosa, ápice emarginado, 0,6-0,9 x 1,1-1,7 cm; istmo amarelo, 3,0-5,0 mm; região do disco com calo tridentado e duas quilhas laterais. Coluna 2,0-4,0 × 1,0 mm, castanha, tábula infraestigmática 1,0-2,0 x 1,0 mm, asas ou estelídios 1,0-2,0 x 1,0-2,0 mm. Fruto não visto.

Cohniella cepula ocorre na Argentina, Bolívia, Paraguai, Peru e Brasil (Cetzal Ix et al., 2012). No Brasil se distribui no Distrito Federal, e nos estados do Acre, Goiás, Mato Grosso, Mato Grosso do Sul, Rondônia e Tocantins, nas regiões Centro-Oeste, Norte e Nordeste e nos biomas Amazônia, Caatinga e Cerrado. Vegeta em matas Mesofíticas (Barros et al., 2015). No Distrito Federal vegeta em Mata Ciliar e Mata Seca Decídua, e floresce especialmente entre os meses de abril e junho.

Material selecionado: APA de Cafuringa, Próximo a República dos Urubus, V.2006, Pellizzaro, K.F. 30 (CEN). FERCAL, Afloramento Calcário na DF-205 esquerda, XII.2000, Batista, J.A.N. 1101 (CEN). Núcleo Rural Sobradinho II, Chacará Tupã-Ipê, IV.2001, Mendes, R.A. 339 (CEN).

3.2. Cohniella jonesiana (Rchb. f.) Christenson. Lindleyana 14(4): 177. 1999.

Pseudobulbos verdes, 0,6-1,1 x 0,3-1,0 cm, protegidos por bainhas paleáceas persistentes, pequenas. Folhas sésseis, estreito-lineares, bases truncadas, ápices agudos, suculentas, verde escuras, 2,2-40,0 x 0,2-2,0 cm. Inflorescência paniculada, 2-10 flores, 30,0-70,0 cm de comp. total. Flores pediceladas, pedicelos, 2,0-2,5 cm de comp. Sépalas similares, obovadas a oblanceoladas, bases bastante atenuadas, margens inteiras, encrespadas, ápices obtusos, membranáceas, brancas densamente pintalgadas de marrom-avermelhado; sépala dorsal, 1,6-2,5 x 0,8-1,3 cm; sépalas laterais parcialmente fundidas na base, 1,8-2,4 x 0,8-1,2 cm. Pétalas oblongas a oblanceoladas, bases atenuadas, margens levemente onduladas, ápices obtusos, membranáceas, brancas densamente pintalgadas de marrom-avermelhado, 2,0-2,6 x 0,8-1,0 cm. Labelo branco pintalgado de vermelho na base, 2,0-2,5 x 2,0-2,6 cm; lobos laterais oblongos, no mesmo plano do lobo mediano, brancos, margens erosas, 0,3-0,6 x 0,5-0,9 cm; lobo 
mediano oboval a espatulado, margem erosa a lacerada, ápice emarginado, 1,2-2,0 x 2,0-2,6 cm; istmo amarelo, 1,0-3,0 cm; região do disco com calo pentadentado, dente central comprimido lateralmente ladeado por quatro dentes menores (dois posteriores e dois anteriores). Coluna $6,0 \times 2,0-4,0 \mathrm{~mm}$, castanha, presença de tábula infraestigmática 2,0-3,0 x 1,0-3,0 mm, asas ou estelídios 1,5-2,0 x 1,0-3,0 mm. Fruto não visto.

Cohniella jonesiana ocorre desde a Argentina, Bolívia, Brasil, e Paraguai (Cetzal Ix et al., 2012). No Brasil se distribui no Distrito Federal, e nos estados de Mato Grosso, Minas Gerais, Paraná e São Paulo, ocorrendo principalmente nas regiões do Centro-Oeste, Sudeste e Sul, e no bioma Cerrado (Cetzal Ix et al., 2012). Vegeta em Mata Ciliar ou Mata de Galeria e Matas Mesofíticas (Barros et al., 2015). Segundo Pellizzaro et al. (2004) a referida espécie vegeta, no Distrito Federal, em Mata Seca Decídua e floresce nos meses dezembro a fevereiro.

OBS: não foram encontrados voucher de herbário para esta espécie. Entretanto, trabalhos como "Estudo do gênero Oncidium" (Pellizzaro et al., 2004) e "A Família Orchidaceae na APA de Cafuringa e sua contribuição para a diversidade da flora do Distrito Federal e do bioma Cerrado" (Bianchetti et al., 2005) registram a ocorrência da espécie para o DF.

A descrição botânica foi realizada a partir do material adicional examinado de Minas Gerais, com adaptações da descrição contida no trabalho de Cetzal Ix et al. (2012).

Material adicional examinado: MINAS GERAIS. Unaí, Região da Gruta do Tamboril, X.2007.

Miranda,

Z.J.G.

93

(CEN).

4. Comparettia Poepp. \& Endl., Nov. Gen. Spec. 1, 42, t. 73 (1835).

Ervas epífitas. Rizoma curto entre os caules secundários. Caules secundários intumescidos em pseudobulbos, alongados a orbiculares, encimados por 1-4 folhas. Folhas conduplicadas, bifaciais, coriáceas, articuladas, geralmente verdes, às vezes pigmentadas de vermelho escuro. Inflorescência lateral, tipo racemo, normalmente excedendo o comprimento das folhas, 5-25 flores. Flores ressupinadas, vistosas, 
vermelhas, alaranjadas, amarelas a rosas. Sépala dorsal livre, as laterais fundidas formando esporão nectarífico. Pétalas livres. Labelo hastado, inteiro, calcarado, base do labelo inserido perpendicularmente na base da coluna, base com dois prolongamentos filiformes divergentes (posicionados dentro do esporão formado pelas sépalas laterais), lobo apical aplanado, bem desenvolvido; região do disco com calo simples, elevado. Coluna não alada, reta; ausência de tábula infraestigmática na base; clinândrio pouco desenvolvido, liso. Fruto cápsula elíptica a ovóide, não a levemente 3angulada; frutos maduros com ápice dos carpelos unidos.

Gênero estabelecido pelo botânico alemão Eduard Friedrich Poeppig e pelo botânico húngaro Stephan Ladislaus Endlicher, em 1835, em homenagem a Andrea Comparetti, fisiologista e professor de botânica em Pádua, Itália (Chase, 2009).

O gênero Comparettia possui cerca de 60 espécies distribuídas desde o México e Índias Ocidentais até a América do Sul, englobando a Bolívia, Peru e Brasil (Chase, 2009). No Brasil ocorrem cinco espécies nos biomas Amazônia, Cerrado e Mata Atlântica. No bioma Cerrado ocorre apenas uma espécie, Comparettia coccinea Lindl., que também está presente no Distrito Federal (Barros et al., 2015).

As espécies de Comparettia possuem flores com um néctario em forma de esporão formado pelas sépalas laterais. Esse esporão é abastecido por um par de glândulas, na base da coluna, que secretam néctar. A polinização por beija-flores é documentada para $C$. falcata. A polinização por borboletas e abelhas de língua longa parece ser provável para algumas espécies (Dodson, 1965; Salguero-Faria \& Ackerman, 1999). Pansarin et al. (2012) apresentam resultados preliminares e mostram que Comparettia coccinea apresenta flores vermelhas com um longo cálcar recurvado formado pela fusão das sépalas laterais. O interior do esporão apresenta tricomas unicelulares responsáveis pela secreção de néctar. Essa espécie é polinizada pelas borboletas Heliconius ethilla narcaea (Godart, 1819) e H. erato phyllis (Fabricius, 1775).

\section{Bibliografia:}

Barros, F. de; Vinhos, F.; Rodrigues, V.T.; Barberena, F.F.V.A.; Fraga, C.N.; Pessoa, E.M.; Forster, W.; Menini Neto, L. 2015 Orchidaceae. In: Lista de Espécies da Flora 
do Brasil. Jardim Botânico do Rio de Janeiro. http://floradobrasil.jbrj.gov.br/jabot/floradobrasil/FB19976 <acesso em: 24/02/2015>

Chase, M.W. 2009. Subtribe Oncidiinae. Pag. 211-391. In: Pridgeon, A.M.; Cribb, P.J.; Chase, M.W. \& Rasmussen, F.N. Genera Orchidacearum. Epidendroideae (Part Two). V. 5. Oxford. University Press.

Dodson C.H. 1965. Agentes de polinización y su influencia sobre la evolución de la familia Orquidacea. Universidade Nacional de la Amazonia Peruana. Iquitos, Peru 1$128 \mathrm{pp}$.

Pansarin, L.M.; Pansarin, E.R.; Santos, I.A. 2012. Biologia floral comparativa entre duas espécies de Oncidiinae (Orchidaceae): Gomesa varicosa M.W.Chase \& N.H.Williams e Comparettia coccínea Lindl. Livro de Resumos. www.63cnbot.com.br (2012).

Salguero-Faria J.A.; Ackerman J.D. 1999. A nectar reward: Is more better?. Biotropica 31: 303-311.

4.1. Comparettia coccinea Lindl. Sketch Veg. Swan 14: t. 68. (1838).

Fig. 1. C-D; 4. C.

Pseudobulbos oblongos, verdes, 0,8-2,5 x 0,2-0,5 cm, encimados por 1 folha; protegidos por bainhas paleáceas persistentes. Folhas sésseis, lanceoladas, bases atenuadas, ápices obtusos, verdes, 8,2-21,2 x 0,8-1,5 cm. Inflorescência 1-6 flores, 8,3$31,0 \mathrm{~cm}$ de comp. total. Flores pediceladas, pedicelos, 1,1-1,5 cm de comp. Sépalas similares, ovais, base levemente atenuada, margem inteira, ápices agudos a mucronados, membranáceas, vermelho-alaranjadas, sépala dorsal $8,0 \times 4,0 \mathrm{~mm}$, sépalas laterais fundidas, 5,0-6,0 x 3,0 mm, esporão 2,0 cm. Pétalas ovais, bases atenuadas, margens inteiras, ápices agudos, membranáceas, vermelho-alaranjadas, 5,0-7,0 x 3,0-4,0 mm. Labelo obovado, base cuneada, margem sinuada, ápice emarginado, vermelhoalaranjado com parte inferior levemente amarelada, 1,6 x 1,6 cm; região do disco com calo bilamelado. Coluna 2,0-3,0 mm, esbranquiçada. Fruto 2,0 x 1,5 cm, elipsóide. 
Comparettia coccinea ocorre na Bolívia, Peru e Brasil (Tropicos, 2014). No Brasil se distribui no Distrito Federal e nos estados da Bahia, Espírito Santo, Minas Gerais, Pernambuco, Rio de Janeiro e São Paulo, nas regiões Centro-Oeste, Nordeste e Sudeste e nos biomas Cerrado e Mata Atlântica. Vegeta em Mata Ciliar ou Mata de Galeria, Mata Seca Semidecídua e Floresta Ombrófila (= Floresta Pluvial) (Barros et al., 2015). No Distrito Federal vegeta em Mata Ciliar, Mata de Galeria não inundável, Mata de Galeria Inundável, com floração nos meses janeiro a março, e frutificando a partir do mês de março.

Material selecionado: Parque Nacional de Brasília, Mata dos Três Barras, III.1999, Santos, A.A. 398 (CEN). Reserva Ecológica do Guará, 1550’00”S, 4757'00’'W, X.1994, Oliveira, R.S. 16 (UB). Taquatinga, Floresta Nacional de Brasília, 1579’02”S, 4808'64”W, X.2012, Lima, J.H. 16 (UB). Várzea Bonita, II.1978, Heringer, E.P. 16751 (IBGE).

5. Coppensia Dumort., Nouv. Mém. Acad. Sci. Bruxelles, 9, 10 (1835).

Ervas terrestres, epífitas ou rupícolas. Rizoma curto a alongado entre os caules secundários. Caules secundários intumescidos em pseudobulbos, fusiformes a ovais, geralmente rugosos e ancipitados, parcialmente recobertos por bainhas foliares, encimados por 2-4 folhas. Folhas conduplicadas, bifaciais, coriáceas, articuladas, verdes. Inflorescência lateral, tipo racemo ou panícula, comprimento maior que as folhas, pauci a multiflora. Flores ressupinadas, explanadas e vistosas, geralmente amarelas com pintas marrons ou vermelhas. Sépala dorsal livre; sépalas laterais fundidas em várias medidas. Pétalas livres, semelhantes às sépalas em tamanho, forma e cor. Labelo trilobado, ecalcarado, base do labelo inserido perpendicularmente na base da coluna, lobos laterais auriculados, lobo intermediário geralmente bastante amplo; região do disco com calo multi-verrucoso ou lamelado, margens do disco e istmo inteiros, nunca denteados ou fimbriados. Coluna com asas semi-circulares ou estelídios ladeando o estigma; presença de proeminente tábula infra-estigmática na base; clinândrio pouco desenvolvido, liso. Fruto cápsula elíptica a ovóide, não a levemente 3angulada; frutos maduros com ápice dos carpelos unidos. 
Gênero estabelecido pelo botânico belga Barthéleny C.J. Dumortier, em 1835, porém na Obra princeps não é realizada qualquer referência à etimologia. Como o sobrenome Coppens é um sobrenome comum na Bélgica e França, possivelmente, seja uma homenagem a Aurèle Augustin Coppens (1668 - 1740), pintor e artista belga autor de uma série de tapeçarias famosas ilustrando a destruição de Bruxelas pelas tropas francesas em 1695.

O gênero possui cerca de 48 espécies (WCSP, 2014) com distribuição neotropical desde a Bolívia, Paraguai, Argentina, Uruguai e Brasil. No Brasil ocorrem 38 espécies (29 endêmicas) em todos os biomas, porém com baixíssima representação nos biomas Amazônia e Caatinga. No bioma Cerrado estão representadas 15 espécies e dessas, duas ocorrem no Distrito Federal (Coppensia hydrophila (Barb.Rodr.) Campacci e Coppensia varicosa (Lindl.) Campacci (Barros et al., 2015).

Grande parte da bibliografia trata de espécies de Gomesa s.l. (hoje incluindo espécies de Coppensia segundo Docha Neto, 2007). Desse modo, muitas observações, especialmente quanto à biologia reprodutiva das espécies, serão referenciadas como pertencentes ao gênero Gomesa.

Espécies do gênero Gomesa comportam grande diversidade floral e biologia reprodutiva (Dressler, 1993). Estudos moleculares (Williams et al., 2001; Chase et al., 2009) mostraram que o "clado Gomesa" é monofilético e que a característica de oferecer óleos como recompensa aos polinizadores está bem representada (Singer et al., 2006). A produção de óleos está relacionada a glândulas especializadas chamadas elaióforos. Aliscioni et al. (2009) e Torreta et al. (2011) demonstram que Gomesa bifolia (Sims) M.W.Chase \& N.H.Williams (=Coppensia bifolia) possui elaióforos nas calosidades e que a estrutura das células secretoras é semelhante àquelas descritas para outras espécies de Oncidiinae. Torreta et al. (2011) mostraram que Gomesa bifolia não apresenta fragrância, e é uma espécie auto-incompatível, não autógama, dependente de polinizadores e que fêmeas de abelhas Centris trigonoides (Apidae, Centridini) foram os polinizadores exclusivos. Ao contrário dos outros comentários generalistas, Pansarin et al. (2012) apresenta resultados preliminares e mostram que Gomesa varicosa não apresenta nenhum tipo de glândula produtora de recurso floral (também confirmado por Stpiczynska et al., 2013) e é polinizada por engano por abelhas Centridini (Epicharis (Epicharana) flava (Friese, 1900) e Centris sp.). 
As espécies de Coppensia são polinizadas por abelhas e geralmente ocorre onde a concentração de indivíduos dessas orquídeas é grande (Miller et al., 2006).

\section{Bibliografia:}

Aliscioni, S.S.; Torretta, J.P.; Bello, M.E.; Galati, B.G. 2009. Elaiophores in Gomesa bifolia (Sims) M.W. Chase \& N.H. Williams (Oncidiinae: Cymbidieae: Orchidaceae): structure and oil secretion. Annals of Botany 14: 1141-1149.

Barros, F. de; Vinhos, F.; Rodrigues, V.T.; Barberena, F.F.V.A.; Fraga, C.N.; Pessoa, E.M.; Forster, W.; Menini Neto, L. 2015 Orchidaceae. In: Lista de Espécies da Flora do Brasil. Jardim Botânico do Rio de Janeiro. http://floradobrasil.jbrj.gov.br/jabot/floradobrasil/FB19976 <acesso em: 24/02/2015>

Chase, M.W. 2009. Subtribe Oncidiinae. Pag. 211-391. In: Pridgeon, A.M.; Cribb, P.J.; Chase, M.W. \& Rasmussen, F.N. Genera Orchidacearum. Epidendroideae (Part Two). V. 5. Oxford. University Press.

Docha Neto, A. 2007. Sinopse taxonômica do gênero Coppensia Dumort.: descrição atualizada e chave das espécies. Orchidstudium - International Journal of Orchid Study 2(1): 14-22.

Dressler RL. 1993. Phylogeny and Classification of the Orchid Family. Dioscorides Press: Portland, Oregon, USA.

Miller, D.; Warren, R.; Miller, I. M. et al. 2006. Serra dos Órgãos, Sua História e Suas Orquídeas. Nova Friburgo, RJ, Ed. Scart. 574 p.

Pansarin, L.M.; Pansarin, E.R.; Santos, I.A. 2012. Biologia floral comparativa entre duas espécies de Oncidiinae (Orchidaceae): Gomesa varicosa M.W.Chase \& N.H.Williams e Comparettia coccínea Lindl. Livro de Resumos. www.63cnbot.com.br (2012). 
Singer, R.B.; Marsaioli, A.J.; Flach, A.; Reis, M.G. 2006. The ecology and chemistry of pollination in Brazilian orchids: recent advances. In: Teixeira da Silva J. (ed.), Floriculture, ornamental and biotechonology: advances and topical issues. Vol. IV. Isleworth: Global Science Books, 570-583 p.

Stpiczynska, M.; Davies, K.L.; Pacek-Bieniek, A.; Kaminska, M. 2013. Comparative anatomy of the floral elaiophore in representatives of the newly re-circumscribed Gomesa and Oncidium clades (Orchidaceae: Oncidiinae). Annals of Botany 112: 839854.

Torretta, J.P.; Gomiz, N.E.; Aliscioni, S.S.; Bello, M.E. 2011. Biologia reproductiva de Gomesa bifolia (Orchidaceae, Cymbidieae, Oncidinae). Darwiniana 49(1): 16-24.

WCSP (2014). 'World Checklist of Selected Plant Families. Facilitated by the Royal Botanic Gardens, Kew. Published on the Internet. http://apps.kew.org/wcsp/ <acesso: 01/06/2014>.

Williams, N. H.; Chase, M. W.; Fulcher, T.; Whitten, W. M. 2001a. Molecular systematics of the Oncidiinae based on evidence from four DNA sequence regions: expanded circumscriptions of Cyrtochilum, Erycina, Otoglossum and Trichocentrum and a new genus (Orchidaceae). Lindleyana 16: 113-139.

\section{CHAVE PARA AS ESPÉCIES COPPENSIA PARA O DISTRITO FEDERAL}

1. Ervas terrestres, inflorescência tipo racemo 1. C. hydrophila

1. Ervas epífitas, inflorescência tipo panícula 2. C. varicosa

5.1. Coppensia hydrophila (Barb. Rodr.) Campacci. Bol. CAOB 62: 55. (2006). Fig. 1. E-F; 4. C.

Erva terrestre. Pseudobulbos esverdeados, 1,9-5,0 x 0,9-2,6 cm, protegidos lateralmente por bainhas foliosas, persistentes, articuladas, 8,0-42,5 cm de comp., 
encimados por 2-3 folhas. Folhas sésseis, estreitamente elípticas a oblanceoladas, bases atenuadas, ápices agudos, 10,2-24 x 1,3-3,5 cm. Inflorescência tipo racemo, 5-40 ou mais flores, 0,6-1,0 $\mathrm{m}$ de comp. total. Flores pediceladas, pedicelos, 0,7-2,0 $\mathrm{cm}$ de comp. Sépalas similares, elípticas, bases levemente estreitadas, margens inteiras, ápices obtusos, membranáceas, totalmente amarelas ou levemente pintalgadas de marromvináceo, sépala dorsal 5,0-7,0 x 2,0-4,0 mm; sépalas laterais $1 \backslash 3$ adnatas, 5,0-9,0 x 1,03,0 mm. Pétalas obovadas, bases levemente estreitadas, margens inteiras, ápices agudos, apiculadas, membranáceas, totalmene amarelas ou levemente pintalgadas de marrom-vináceo, 5,0-7,0 x 3,0-5,0 mm. Labelo amarelo, 1,4-1,8 x 1,6-2,0 cm; lobos laterais transversalmente elípticos, amarelos, 1,0-4,0 x 2,0-4,0 mm; lobo mediano oval, margem sinuada, ápice emarginado, 0,8-1,3 x 1,6-2,0 cm; istmo 2,0-3,0 mm, amarelo; região do disco com calo verrucoso envolvendo estruturas dentiformes e cristas (região mediana bidentado; região anterior tri-cristado). Coluna 3,0-5,0 x 1,0-1,5 mm, castanho, tábula infra estigmática 2,0 x 1,0-2,0 mm, asas ou estelídios 2,0-3,0 x 1,0-2,0 mm. Fruto não visto.

Coppensia hydrophila ocorre no Paraguai e Brasil (Tropicos, 2014). No Brasil se distribui no Distrito Federal e nos estados da Bahia, Espírito Santo, Goiás, Minas Gerais, Paraná, Pernambuco, Rio de Janeiro, Rio Grande do Sul, Santa Catarina, São Paulo e Tocantins, nas regiões Centro-Oeste, Nordeste, Sudeste e Sul, especialmente no bioma Cerrado. Vegeta em ambientes ricos em umidade, como Campos de Altitude, Campo Limpo, Campo Rupestre (Barros et al., 2015). No Distrito Federal vegeta em ambientes de Campo úmido, Brejo e Campo Rupestre, e floresce nos meses de outubro a janeiro.

Material selecionado: Below Velhacap, Close to Nucleo Bandeirante, XI.1978, Ratter, J. 4293 (UB). Fazenda Água Limpa da UnB, Córrego Taquara, 15³6"S, 4754”W, XI.2003, Pinagé, E.R. s.n. (UB14529). Fundação Zoobotânica de Brasília, XI.1961, Heringer, E.P. 8447 (NY). Lago Sul, Campo as margens do Córrego do Gama, X.1998, Batista, J.A.N. 800 (CEN). Parque Boca da Mata, XI.1995, Rezende, J.M. 255 (CEN). Reserva Ecológica do Guará, X.1990, Batista, J.A.N. 118 (CEN). Reserva Ecológica do IBGE, X.1979, Heringer, E.P. 3744 (IBGE). Santuário Ecológico do Riacho Fundo, XI.1994, Oliveira, R.S. 28 (UB). Setor Industrial, XII.1965, Belém, R.P. 1896 (UB). 
Oncidium hydrophilum var. immaculatum L.C.Menezes, também é citado para o Distrito Federal e considerado, pela Lista de Espécies da flora do Brasil (2014), como sinônimo de Coppensia hydrophila (Barb. Rodr.) Campacci. Em exame do material tipo (UB! Brasília. Reserva Ecológica do Guará. X.1990, Menezes, L.C. 8) foi observado à inexistência de flores e de inflorescências.

Ainda quanto à var. immaculatum, vários autores consideram que a ausência de antocianina em duas plantas de uma população seria melhor tratada como forma e não como variedade (Christenson, 1996; Barros \& Batista, 2004).

\subsection{Coppensia varicosa (Lindl.) Campacci Bol. CAOB 62: 57. (2006).}

Fig. 4. C.

Erva epífita. Pseudobulbos ovato-oblongos, verdes com sulcos pintalgados de maromvináceo, 3,5-7,8 x 0,9-2,8 cm, protegidos por bainhas foliáceas articuladas, persistentes, 7,1-15,5 cm de comp., encimados por 2-3 folhas. Folhas elípticas a obovaladas, base atenuadas, ápices agudos, 16,0-30,0 x 1,0-4,0 cm. Inflorescência tipo panícula, 20 a pouco mais de 100 flores, 80,0-116,0 cm de comp. total. Flores pediceladas, pedicelos 1,2-3,1 cm de comp. Sépalas similares, elípticas, bases levemente estreitadas, margens inteiras, ápices agudos, membranáceas, amarelas pintalgadas de marrom-avermelhado, sépala dorsal 0,7-1,2 x 0,3-0,6 cm; sépalas laterais adnatas $1 / 3$ a metade, 0,8-1,5 x 0,2$0,6 \mathrm{~cm}$. Pétalas ovais, bases atenuadas, margens levemente sinuosas, ápices obtusos, mucronados, membranáceas, amarelas pintalgadas de marrom-avermelhado, 0,8-1,2 x 0,3-0,7 cm. Labelo amarelo, 2,3-3,5 x 2,2-4,1 cm; lobos laterais obovados a subrotundados, amarelos, 0,3-0,5 x 0,3-0,5 cm; lobo mediano largo reniforme, levemente constricto em direção ao ápice dando a impressão de ser tetra-lobado, ápice emarginado, 1,4-3,0 x 2,2-4,1 cm; região do disco geralmente pintalgada de marrom-avermelhado com calo verrucoso envolvendo estruturas dentiformes e cristas (região mediana bidentado; região anterior tri-cristado). Coluna 4,0-5,0 x 1,0 mm, castanha, tábula infraestigmática 2,0 x 1,0 mm, asas ou estelídios 3,0 x 1,0-2,0 mm. Fruto não visto.

Coppensia varicosa ocorre na Bolívia, Paraguai e Brasil (Tropicos, 2014). No Brasil se distribui no Distrito Federal e nos estados da Bahia, Goiás, Minas Gerais, Paraná, Santa Catarina e São Paulo, nas regiões Centro-Oeste, Nordeste e Sudeste e Sul 
e nos biomas Caatinga, Cerrado e Mata Atlântica. Vegeta em Campo Rupestre, Mata Ciliar ou Mata de Galeria, Mata Seca Semidecídua, Floresta Ombrófila (= Floresta Pluvial) (Barros et al., 2015). No Distrito Federal vegeta em ambiente de Mata Ciliar, Mata de Galeria e floresce principalmente nos meses de janeiro a abril.

Material selecionado: ARIE Cerradão, 1551”S, 4749”W, I.2008, Silva, J.S. 318 (UB). Bacia do Rio São Bartolomeu, VII.1979, Heringer, E.P. 1831 (IBGE). Cabeça de Veado, III.1961, Heringer, E.P. 8065 (UB). Catetinho, II.1979, Salles, A.E.H. 3 (IBGE). EEJBB, Captação d'agua do JBB, 1552S, 4751”W, IV.2013, Soares, A.C.A. s.n. (HEPH29268). Fazenda da Universidade de Brasília (Fazenda Água Limpa), Mata do Córrego do Gama, III.1992, Bianchetti, L. 1239 (CEN).

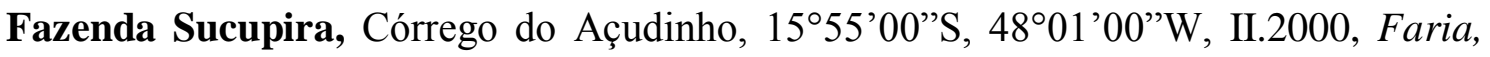
J.G. 254 (CEN). Grota atrás do cemitério do Gama, 1601'S, 4803'W, IX.1996, Gomes, S.M. 86 (CEN). Reserva Ecológica do IBGE, Córrego Taquara. 1556’S, 4755'W, III.1994, Walter, B.M.T. 2091 (CEN).

6. Ionopsis Kunth, Nov. Gen. Spec. Pl., 1, 348, t. 83 (1816).

Ervas epífitas. Rizoma curto entre os caules secundários. Caules secundários intumescidos em pseudobulbos, inconspícuos, sempre encobertos pelas bainhas foliares, encimados por 1 folha. Folhas conduplicadas, bifaciais, coriáceas, articuladas, verdes ou arroxeadas. Inflorescência lateral, tipo panícula, comprimento maior que as folhas, uni a multiflora. Flores ressupinadas, explanadas e vistosas, verdes, rosadas a violetas. Sépala dorsal livre; sépalas laterais parcialmente fundidas e na base formando pequeno mento. Pétalas livres, similares às sépalas. Labelo inteiro, obovado, ecalcarado, base do labelo inserido perpendicularmente na base da coluna, região médio-apical bastante dilatada, ápice emarginado; região do disco com calo bilamelado. Coluna não alada, levemente dilatada no ápice; ausência de tábula infraestigmática; clinândrio pouco desenvolvido, liso. Fruto cápsula elíptica a ovóide, não a levemente 3angulada; frutos maduros com ápice dos carpelos unidos.

Gênero estabelecido pelo botânico alemão Carl Sigismund Kunth, em 1816, em alusão à semelhança superficial entre as flores da primeira espécie descrita para o 
gênero e aquelas das violetas (grego: $i o n=$ violeta e opis = aparência, semelhança) (Chase, 2009).

O gênero possui três espécies, amplamente distribuídas nos Neotrópicos, desde o sul da Flórida, na América Central e do Sul (Chase, 2009). No Brasil ocorrem três espécies nos biomas Amazônia, Cerrado, Mata Atlântica. No bioma Cerrado, e no Distrito Federal, está representada por apenas uma espécie, Ionopsis utricularioides (Benth.) Lindl. (Barros et al., 2015).

As espécies de Ionopsis possuem flores cor de rosa ou brancas com um labelo inteiro, bem desenvolvido em relação às outras peças florais, com um pequeno mento formado pelas sépalas laterias. As flores não oferecem qualquer recompensa e provavelmente são polinizadas por engano por abelhas que buscam néctar (Neubig et al., 2012). Trabalho elaborado por Aguiar (2014) mostra que I. utricularioides apresenta osmóforos nas protuberâncias localizadas na base do labelo e, ao redor delas, e papilas secretoras, capazes de produzir determinadas fragrâncias que atraem abelhas, porém ainda não foram registrados quais tipos de abelhas.

\section{Bibliografia:}

Aguiar, J.M.R.B.V. 2014. Biologia reprodutiva das Ionopsis Kunth (Orchidaceae) do Brasil. Tese de Mestrado. Universidade de São Paulo. Ribeirão Preto. 63 p.

Barros, F. de; Vinhos, F.; Rodrigues, V.T.; Barberena, F.F.V.A.; Fraga, C.N.; Pessoa, E.M.; Forster, W.; Menini Neto, L. 2015 Orchidaceae. In: Lista de Espécies da Flora do Brasil. Jardim Botânico do Rio de Janeiro. http://floradobrasil.jbrj.gov.br/jabot/floradobrasil/FB19976 <acesso em: 24/02/2015>

Chase, M.W. 2009. Subtribe Oncidiinae. Pag. 211-391. In: Pridgeon, A.M.; Cribb, P.J.; Chase, M.W. \& Rasmussen, F.N. Genera Orchidacearum. Epidendroideae (Part Two). V. 5. Oxford. University Press.

Neubig, K.M., W. M. Whitten, N. H. Williams, M. A. Blanco, L. Endara, J. G. Burleigh, K. Silvera, J. C. Cushman, \& M. W. Chase. 2012. Generic recircumscriptions of Oncidiinae (Orchidaceae: Cymbidieae) based on maximum likelihood analysis of combined DNA datasets. Botanical Journal of the Linnean Society 168: 117-146. 
6.1. Ionopsis utricularioides (Sw.) Lindl. Coll. Bot. 8: t. 39, f. A. (1826).

Fig. 3. E-F; 4. D

Pseudobulbos elípticos a ovóides, verdes, 0,4-2,7 x 0,1-0,8 cm, escondidos por bainhas. Folhas ou bainhas foliosas com limbo desenvolvido, persistentes, oblongas ou linearliguladas 5,0-15,2 x 0,8-1,2 cm. Inflorescência 9-150 flores ou mais, 21,0-66,0 cm de comp. total. Flores pediceladas, pedicelos, 0,4-1,0 $\mathrm{cm}$ de comp. Sépalas similares, ovaladas a elípticas, bases atenuadas, ápices agudos, margens inteiras, membranáceas, lilases, sépala dorsal 4,0-5,0 x 1,0-2,0 mm; sépalas laterais fundidas até a metade, 4,05,0 x 1,0-2,0 mm. Pétalas obovadas, bases atenuadas, ápices obtusos, margens inteiras, membranáceas, lilases, 4,0-6,0 x 2,0-3,0 mm. Labelo lilás a branco, base cuneada, margem inteira, ápice emarginado, 0,8-2,0 x 1,0-1,5 cm. Coluna 1,0-2,0 mm, coloração acastanhada. Fruto não visto.

Ionopsis utricularioides ocorre em parte da América do Norte, Central e do Sul, desde a Florida (USA) até Argentina e Brasil (Aguiar, 2014). No Brasil se distribui no Distrito Federal e nos estados do Acre, Amazonas, Bahia, Goiás, Pará, Paraná, Pernambuco, Maranhão, Mato Grosso, Mato Grosso do Sul, Minas Gerais, Rio de Janeiro, Rondônia, Sergipe, Santa Catarina e São Paulo, nas regiões Centro-Oeste, Nordeste, Norte, Sudeste e Sul, e nos biomas Amazônia, Cerrado, Mata Atlântica, em condições naturais ou em ambientes antropizados. Vegeta em Mata Ciliar ou Mata de Galeria, Floresta de Igapó, Floresta de Terra Firme, Mata Seca Decídua, Floresta Estacional Perenifólia, Mata Seca Semidecídua, Floresta Ombrófila (= Floresta Pluvial) (Barros et al., 2015). No Distrito Federal ocorre em Mata de galeria Inundável e Mata mesofítica (Mata Seca Decídua), e floresce nos meses junho a dezembro.

Material selecionado: APA de Cafuringa, República dos Urubus, XII.2002, Pellizzaro, K.F. 28 (CEN). FERCAL, APA de Cafuringa, VIII.1990, Vieira, R. 361 (CEN). Jardim Botânico de Brasília, $15^{\circ} 52^{\prime}$ S, 4751'W, VIII.2000, Nóbrega, M.G. 1294 (HEPH). Reserva Ecológica do Guará, VIII.1999, Batista, J.A.N. 935 (CEN). Margem do Ribeirão Jacaré, cortada pela DF-100, VI.1991, Bianchetti, L. sn. (CEN15096). 
7. Lockhartia Hook., Bol. Mag., 54, t. 2715 (1827).

Ervas epífitas. Rizoma curto entre os caules secundários. Caules secundários não intumescidos em pseudobulbos, eretos ou pêndulos, cobertos por folhas curtas. Folhas unifaciais, carnosas, bases equitantes ou imbricadas, não-articuladas, verdes. Inflorescência curta, lateral ou terminal, tipo racemo ou panícula, comprimento menor ou igual às folhas, pauciflora; brácteas alargadas, semi-orbiculares. Flores geralmente ressupinadas, pequenas, geralmente amarelas com manchas vermelhas ou marrons escuras. Sépalas e Pétalas livres, semelhantes em tamanho e forma. Labelo geralmente trilobado, ecalcarado, base do labelo inserido perpendicularmente na base da coluna, lobo apical bilobado, oblongo a quase circular; lobos laterais muitas vezes lineares e arqueados; região do disco com calo simples a complexo, tuberculado ou com chifres. Coluna geralmente alada ou com pequenas asas ladeando o estigma; ausência de tábula infraestigmática; clinândrio pouco desenvolvido, liso. Fruto cápsula elipsóide a suborbicular, não 3-angulada; frutos maduros com ápice dos carpelos livres e reflexos.

Gênero estabelecido pelo botânico inglês William Jackson Hooker, em 1827, em homenagem a David Lockhart, superintendente do Jardim Botânico Imperial de Trinidade e Tobago, durante o século XVIII (Chase, 2009).

O gênero possui cerca de 30 espécies de distribuição neotropical, que se estende da América do Norte (México) a América do Sul (Venezuela, Guiana Francesa, Bolívia, Peru, Trinidade e Brasil) (Chase, 2009). No Brasil ocorrem sete espécies (quatro endêmicas), distribuídas nos biomas Amazônia, Mata Atlântica e Cerrado. No bioma Cerrado ocorre apenas uma espécie, Lockhartia goyazensis Rchb.f., que está presente no Distrito Federal (Barros et al., 2015).

Não existem informações sobre mecanismos de polinização e de polinizadores para espécies de Lockhartia. Entretanto, a morfologia floral, especialmente a morfologia do calo indicam pertencerem ao grupo de Oncidiinae com flores que produzem óleos e, provavelmente, sejam polinizadas por abelhas coletoras de óleos, similares a outras espécies de Oncidium que exibem essa síndrome (Chase, 2009). 


\section{Bibliografia:}

Barros, F. de; Vinhos, F.; Rodrigues, V.T.; Barberena, F.F.V.A.; Fraga, C.N.; Pessoa, E.M.; Forster, W.; Menini Neto, L. 2015 Orchidaceae. In: Lista de Espécies da Flora do Brasil. Jardim Botânico do Rio de Janeiro. http://floradobrasil.jbrj.gov.br/jabot/floradobrasil/FB19976 <acesso em: 24/02/2015>

Chase, M.W. 2009. Subtribe Oncidiinae. Pag. 211-391. In: Pridgeon, A.M.; Cribb, P.J.; Chase, M.W. \& Rasmussen, F.N. Genera Orchidacearum. Epidendroideae (Part Two). V. 5. Oxford. University Press.

7.1. Lockhartia goyazensis Rchb.f. Bot. Zeitung (Berlin) 10: 768. (1852). Fig. 2. A-B; 4. D.

Folhas sésseis, triangulares, em vista lateral, e largamente ovadas, em vista frontal distendida, base truncada, ápice agudo a levemente rotundado, 1,0-2,3 x 0,3-1,4 cm. Inflorescência racemo, 2-4 flores, 1,0-1,6 cm de comp. total; 2-4 brácteas petalóides, patentes, ovais, ápice agudo, castanho claras, 2,0-4,0 mm de comp. Flores pediceladas, pedicelos 1,0-7,0 mm de compr. Sépalas dorsal e laterais obovadas, bases truncadas, margens inteiras, ápices obtusos, membranáceas, amarelas, 3,0-4,0 x 2,0-3,0 mm; Pétalas elípticas, bases truncadas, ápices rotundados, margens inteiras, membranáceas, amarelas, 3,0-4,0 x 2,0-3,0 mm. Labelo amarelo com manchas no centro marrom, 5,06,0 x 7,0-9,0 mm; lobos laterais lineares, amarelos, 3,0-4,0 x 0,8 mm; lobo mediano obovado-subquadrado, margem repanda, ápice emarginado, 3,0-4,0 x 3,0-5,0 cm; região do disco com calo complexo, tuberculoso, ocupando a parte basal e central do lobo mediano. Coluna 2,0 x 1,0 mm, castanha. Fruto 11,0 x 6,0 mm, oblongo.

Lockhartia goyazensis ocorre na Bolívia e Brasil (Tropicos, 2014). No Brasil se distribui no Distrito Federal e nos estados do Amapá, Amazonas, Espírito Santo, Goiás, Maranhão, Mato Grosso, Mato Grosso do Sul, Minas Gerais, Pará, Pernambuco, Rondônia, Sergipe e Tocantins, nas regiões Centro-Oeste, Nordeste, Norte e Sudeste e nos Biomas Amazônia e Cerrado. Vegeta em Mata Ciliar ou Mata de Galeria, Floresta de Terra Firme, Floresta de Várzea, Mata Seca Semidecídua (Barros et al., 2015). No Distrito Federal ocorre em Mata mesofítica de encosta (Mata Seca Decídua) e Mata de 
Galeria, floresce nos meses de julho a outubro, e frutificando nos meses de outubro a dezembro.

Material selecionado: APA de Cafuringa, Fazenda Palestina, X.1992, Pereira, B.A.S. 2271 (CEN, IBGE). FERCAL, Morro da pedreira, 15³0'40”S, 4757’36”W, XI.2014, Queiroz, V.V. 15 (UB). Margem direita do Rio Preto, $16^{\circ} 02^{\prime}$ S, 47 ${ }^{\circ} 19^{\prime} \mathrm{W}$, X.2002, Rezende, J.M. 662 (CEN).

Material adicional examinado: GOIÁS. Luziânia, Fazenda do Sr. Silas, margem direita do rio Corumbá, VI.2003, Pereira-Silva, G. 7769 (CEN). Formosa, Salto do Itiquira, 15²1'59,8’S, 47²7’13,5”'W, XII.2014, Queiroz, V.V. et al., 18 (UB). Paraúna, Ponte de Pedra, IV.1992, Batista, J.A.N. 300 (CEN).

8. Lophiaris Raf., Fl. Tellur., 4, 40 (1836).

Ervas epífitas. Rizoma curto entre os caules secundários. Caules secundários intumescidos em pseudobulbos, muito reduzidos, subcilíndricos, encimados por uma folha. Folhas conduplicadas, bifaciais, carnosas, articuladas, verdes, geralmente pintalgadas de roxo. Inflorescência lateral, tipo racemo ou panícula, comprimento maior que as folhas, multiflora. Flores ressupinadas, pequenas a grandes, pouco a muito vistosas, com combinação de cores amarela, branco, púrpura e marrom, geralmente pintalgadas. Sépalas laterais algo conadas, sépala dorsal e pétalas livres, semelhantes entre si, venação reticulada, papilosas nas superfícies externas. Labelo trilobado, ecalcarado, base do labelo inserido perpendicularmente na base da coluna; lobos laterais pequenos em relação ao lobo mediano; região do disco com calo complexo (1-2 séries de dentes, quilha central). Coluna alada, asas ou estelídeos ladeando o estígma; presença de tábula infra-estigmática; clinândrio pouco desenvolvido, liso. Fruto cápsula elipsóide, não a levemente 3-angulada; frutos maduros com ápice dos carpelos unidos.

Gênero estabelecido pelo botânico Constantine Samuel Rafinesque em 1836, porém na Obra princeps não é feita referência à etimologia, mas por dedução possivelmente do grego lophos crista e, - aris um sufixo que significa "provido de", provavelmente uma alusão à série de dentes no calo que se assemelha a uma crista. 
O gênero possui cerca de 36 espécies distribuídas desde a Flórida, México, América Central, até a Argentina e Brasil (WCSP, 2014). No Brasil ocorrem seis espécies (uma endêmica), nos biomas Amazônia, Cerrado e Mata Atlântica. No bioma Cerrado estão representadas duas espécies e dessas apenas Lophiaris pumila (Lindl.) Braem ocorre no Distrito Federal (Barros et al., 2015).

As espécies de Lophiaris apresentam flores predominantemente amarelas ou róseas. Aquelas que possuem flores amarelas apresentam manchas amarronzadas e calosidades típicas de flores que produzem óleo ou resina como recompensa e, provavelmente, são visitadas por abelhas dos gêneros Centris e Paratetrapedia (Silvera, 2002); Parra-Tabla et al. (2000) comentam que flores de Lophiaris também são polinizadas por abelhas dos gêneros Trigona e que algumas espécies são polinizadas por engano. Pansarin \& Pansarin (2011) registram que, embora a calosidade lamelada de Trichocentrum pumilum Lindl. (= Lophiaris pumila) lembre um elaióforo, ela não produz óleo como recompensa aos polinizadores. Por outro lado, os lobos laterais apresentam tricomas alongados que produzem e armazenam substâncias lipoidais, responsáveis pela atração e polinização realizada por duas espécies de abelhas (Tetrapedia diversipes e Lophopedia nigrispinis).

\section{Bibliografia:}

Braem, G.J., 1993. Studies in the Oncidiinae - discussion of some taxonomic problems with description of Gudrunia Braem, gen. nov. and reinstatement of the genus Lophiaris Rafinesque. Schlechteriana 1-2/93: 17-21.

Chase, M.W. 2009. Subtribe Oncidiinae. Pag. 211-391. In: Pridgeon, A.M.; Cribb, P.J.; Chase, M.W. \& Rasmussen, F.N. Genera Orchidacearum. Epidendroideae (Part Two). V. 5. Oxford. University Press.

Pansarin, E. R., Pansarin, L. M. 2011. Reproductive biology of Trichocentrum pumilum: an orchid pollinated by oil-collecting bees. Plant Biology (Stuttgart): 576-581.

Parra-Tabla V, Vargas CF, Magana-Rueda S, Navarro J. 2000. Female and male pollination success of Oncidium ascendens Lindey (Orchidaceae) in two contrasting habitat patches: forest vs agricultural field. Biological Conservation 94: 335-340. 
Silvera K. 2002. Adaptive radiation of oil-reward compounds among neotropical orchid species (Oncidiinae). Unpublished M.S. thesis, University of Florida.

WCSP (2014). 'World Checklist of Selected Plant Families. Facilitated by the Royal Botanic Gardens, Kew. Published on the Internet: http://apps.kew.org/wcsp/ <acesso: 01/06/2014>.

8.1. Lophiaris pumila (Lindl.) Braem. Schlechteriana 4: 21 (1993).

Fig. 5. A

Pseudobulbos verdes, 0,2-0,8 x 0,2-0,3 cm, protegidos lateralmente por bainhas paleáceas. Folhas sésseis, obovadas a elípticas, bases atenuadas, ápices agudos, verde claras, 4,4-16,5 cm. Inflorescência tipo panícula, 60-150 ou mais flores, 7,0-23,5 cm de comp. total. Flores curtamente pediceladas, pedicelos 1,0-2,0 mm. Sépalas similares oval-oblongas, bases atenuadas, margens inteiras, ápices obtusos, membranáceas, amarelo-queimadas, sépala dorsal 1,0-2,0 x 0,6-1,5 mm; sépalas laterais 113 adnatas, 1,5-2,5 x 0,6-1,5 mm. Pétalas elípticas a subspatuladas, bases atenuadas, margens inteiras, ápices obtusos, membranáceas, amarelo-queimadas, 1,0-2,1 x 0,8-1,1 mm. Labelo esbranquiçado a amarelo-queimado, 2,0-4,0 x 0,8-1,1 mm; base levemente cordada; lobos laterais triangulo-ovados, amarelo-queimados, 1,3-1,9 x 1,5-2,1 mm; lobo mediano obovado, ápice inteiro, obtuso, amarelo, 0,5-1,7 x 0,8-1,1 mm; região do disco com calo 4-carenados. Coluna 1,0-1,1 x 0,4-0,5 mm, castanha, tábula infraestigmática $0,5 \times 0,4-0,5 \mathrm{~mm}$, asas ou estelídios $0,3-0,5 \times 0,4-0,6 \mathrm{~mm}$. Fruto $8,0 \mathrm{x}$ 5,0-6,0 mm, oblongo a ovóide.

Lophiaris pumila ocorre na Argentina, Bolívia e Brasil (Tropicos, 2014). No Brasil se distribui no Distrito Federal e nos estados da Bahia, Espírito Santo, Goiás, Mato Grosso, Mato Grosso do Sul, Minas Gerais, Pará, Paraná, Rio de Janeiro, Rio Grande do Sul, Santa Catarina, São Paulo e Sergipe, nas regiões do Centro-Oeste, Nordeste, Norte, Sudeste e Sul, e nos biomas da Amazônia, Caatinga, Cerrado e Mata Atlântica. Vegeta em Mata Ciliar ou Mata de Galeria, Floresta de Terra Firme, Mata Seca Decídua, Mata Seca Semidecídua, Floresta Ombrófila (= Floresta Pluvial), Floresta Ombrófila Mista, Restinga (Barros et al., 2015). No Distrito Federal vegeta em 
ambientes de Mata Ciliar, Mata de Galeria inundável, Mata Mesofítica Decídua, Mata semi-decídua com afloramento calcário, e floresce nos meses de novembro a maio, e frutificando nos meses de fevereiro a maio.

Material selecionado: APA de Cafuringa, Fazenda dois irmãos, XII.2002, Pellizzaro, K.F. 33 (CEN). Caminho da FERCAL, próximo a ponte Rio Maranhão, IV.1979, Bianchetti, L. 414 (HEPH). Córrego Cabeça de Veado, 1552'S, 4751'O, XII.1993, Ramos, A.E. 577 (HEPH). DF-100 sentido BSB-Formosa, Fazenda Manga, $15^{\circ} 57^{\prime}$ S, 47²2'O, XI.2002, Santos, A.A. 1698 (CEN). FERCAL, Mata a direita da DF205, I.1992, Batista, J.A.N. 261 (CEN). Jardim Botânico de Brasília, Porção acima da área de lazer, $15^{\circ} 52^{\prime} \mathrm{S}, 4^{\circ} 51^{\prime} \mathrm{O}$, V.1999, Ramos, A.E. 1301 (HEPH). Reserva Ecológica do Jardim Botânico de Brasília, Mata de galeria do Córrego Cabeça de Veado, II.2003, Pellizzaro, K.F. 54 (CEN). Santuário Ecológico do Riacho Fundo, 1551'S, 4757’O, II.1995, Oliveira, R.S. 64 (UB). Sobradinho dos Melos, Fazenda Sr. Benedito de Jesus A. Reis, $15^{\circ} 47^{\prime}$ S, 47²4'O, V.2005, Salles, A.E.H. 3761 (HEPH).

9. Macroclinium Barb.Rodr., Gen. Sp. Orch. Nov., 2, 236 (1882).

Ervas epífitas. Rizoma curto entre os caules secundários. Caules secundários intumescidos ou não em pseudobulbos, se presentes então reduzidos, ancipitados, encimados por 1-folha. Folhas ensiformes, flabeliformes, unifaciais, carnosas, articulada, verdes, superfície geralmente reticulada ou rugosa. Inflorescências tipo racemo sub-umbelado (com flores congestas no ápice), comprimento maior que as folhas, multiflora. Flores geralmente ressupinadas, pequenas, geralmente coloridas de branco, rosa ou roxo. Sépalas e Pétalas livres, semelhantes em tamanho e forma. Labelo inteiro a levemente trilobado, espatulado a hastado, ecalcarado, base do labelo inserido perpendicularmente na base da coluna, base longe-unguiculada, terete; região do disco com calo simples, elevado. Coluna não alada, levemente reflexa, ausência de tábula infraestigmática, clinândrio pouco desenvolvido, liso. Fruto cápsula elipsóide, não a levemente 3-angulada; frutos maduros com ápice dos carpelos unidos.

Gênero estabelecido pelo botânico brasileiro Barbosa Rodrigues, em 1882, em alusão ao grande rostelo observado na espécie tipo (Chase, 2009). 
O gênero possui cerca de 40 espécies de distribuição neotropical, do México, através da América Central (exceto as Antilhas) para o Peru e Brasil tipo (Chase, 2009). No Brasil ocorrem cinco espécies (três endêmicas) nos biomas da Amazônia e Cerrado. No bioma Cerrado ocorre apenas uma espécie, Macroclinium wullschlaegelianum (Focke) Dodson, que está presente no Distrito Federal (Barros et al., 2015).

As espécies de Macroclinium possuem flores delicadas com sépalas, pétalas, e labelos estreitos. Apesar de seu pequeno tamanho, as flores são perfumadas e atraem abelhas relativamente grandes (Neubig et al., 2012). As espécies de Macroclinium não produzem néctar e os polinizadores são os mesmos daqueles observados para espécies de Notylia, machos de abelhas Euglossini, que coletam fragrâncias florais (Chase, 2009).

\section{Bibliografia:}

Barros, F. de; Vinhos, F.; Rodrigues, V.T.; Barberena, F.F.V.A.; Fraga, C.N.; Pessoa, E.M.; Forster, W.; Menini Neto, L. 2015 Orchidaceae. In: Lista de Espécies da Flora do Brasil. Jardim Botânico do Rio de Janeiro. http://floradobrasil.jbrj.gov.br/jabot/floradobrasil/FB19976 <acesso em: 24/02/2015>

Chase, M.W. 2009. Subtribe Oncidiinae. Pag. 211-391. In: Pridgeon, A.M.; Cribb, P.J.; Chase, M.W. \& Rasmussen, F.N. Genera Orchidacearum. Epidendroideae (Part Two). V. 5. Oxford. University Press.

Neubig, K.M., W. M. Whitten, N. H. Williams, M. A. Blanco, L. Endara, J. G. Burleigh, K. Silvera, J. C. Cushman, \& M. W. Chase. 2012. Generic recircumscriptions of Oncidiinae (Orchidaceae: Cymbidieae) based on maximum likelihood analysis of combined DNA datasets. Botanical Journal of the Linnean Society 168: 117-146. 
9.1. Macroclinium wullschlaegelianum (H.Focke) Dodson. Icon. Pl. Trop. 10: t. 939 (1984).

Fig. 2. E-F; 5. A

Pseudobulbos elípticos, castanho-esverdeado, 3,0-7,0 x 1,0-3,0 mm, sem bainhas. Folhas sésseis, elípticas, bases truncadas, ápices agudos, verdes, 0,7-3,4 x 0,2-0,5 cm. Inflorescência 3-10 flores, 3,0-7,5 cm de comp. total. Flores pediceladas, pedicelos 0,2-1,4 cm. Sépalas similares, elíptico-lineares, bases atenuadas, margens inteiras, ápices acuminados, membranáceas, amareladas (cremes), sépala dorsal 8,0-11,0 x 1,02,0 mm; sépala lateral livres, 9,0-10,0 × 0,1 mm. Pétalas elíptica-lineares, bases atenuadas, margens inteiras, ápices acuminados, membranáceas, amareladas pintalgadas de roxo, 7,0-9,0 x 1,0 mm. Labelo roxo, 7,0-9,0 x 2,0-3,0 mm; lobos laterais (aurícolas) triangulares muito pouco desenvolvidos com pequena calosidade entre eles, região mediana estreitamente oblonga, 2,0-3,0 mm de comp., base unguiculada $2,5 \times 0,3-0,4$ mm, unguiculo $1,0 \times$ x 0,1-0,2 mm, região apical cordato-triangular, margens levemente erosas, 4,0-6,0 x 2,0-3,0 mm. Coluna 9,0-10,0 x 0,2-0,3 mm, castanha. Fruto 8,0 x $5,0 \mathrm{~mm}$, oblongo.

Macroclinium wullschlaegelianum ocorre na Colômbia, Guiana Francesa, Guiana, Panamá, Peru, Suriname, Venezuela e Brasil (Tropicos, 2014). No Brasil se distribui no Distrito Federal e nos estados do Amazonas, Goiás, Maranhão, Pará e Rondônia, nas regiões Centro-Oeste, Nordeste e Norte, e nos biomas Amazônia e Cerrado. Vegeta em Mata Ciliar ou Mata de Galeria, Floresta de Igapó, Floresta de Terra Firme, Floresta de Várzea (Barros et al., 2015). No Distrito Federal ocorre em ambientes de Mata de Galeria inundável e floresce nos meses de fevereiro a abril, e frutificando nos meses de abril a agosto.

Material selecionado: Mata no entroncamento da DF-100, Ribeirão Jacaré, IV.1992, Bianchetti, L. 1240 (CEN). DF-130, Rio Maranhão, II.1999, Batista, J.A.N. 878 (CEN). Fazenda dos Guimarães, Próximo do CPAC/EMBRAPA, VIII.1991, Batista, J.A.N. 205 (CEN). Marginais do Rio Vicente Pires, II.1961, Heringer, E.P. 7898 (UB). 
Material adicional examinado: GOIÁS. Formosa, Margem direita do rio Bezerra, III.2002, Pereira-Silva, G. 5973 (CEN). Luziânia, Fazenda Suindara do Alagado, XI.2002, Pereira-Silva, G. 6947 (CEN).

10. Notylia Lindl., Bot. Reg., 11, sub. T. 930 (1825).

Ervas epífitas. Rizoma curto entre os caules secundários. Caules secundários intumescidos em pseudobulbos, esféricos a estreitamente elípticos, encimados por 1-2 folhas. Folhas bifaciais, conduplicadas, coriáceas, articuladas, verdes. Inflorescência lateral, tipo racemo, pendente, comprimento maior que as folhas, multiflora. Flores ressupinadas, pequenas, cremes, brancas, amarelas ou verdes, às vezes com marcas amarelas nas pétalas. Sépalas e pétalas similares, sépala dorsal livre, sépalas laterais parcialmente fundidas. Labelo inteiro, hastado, ecalcarado, base do labelo inserido perpendicularmente na base da coluna, base unguiculada, terete; região do disco com calo simples, geralmente alongado, carenado. Coluna não alada, levemente reflexa; ausência de tábula infraestigmática; clinândrio pouco desenvolvido, liso. Fruto cápsula elipsóide a suborbicular, não a levemente 3-angulada; frutos maduros com ápice dos carpelos unidos.

Gênero estabelecido pelo botânico inglês John Lindley, em alusão à singular porção apical recurvada da coluna (Chase, 2009).

O gênero possui cerca de 60 espécies, distribuídas a partir do México, e na América Central, Panamá, Colômbia, Venezuela, Bolívia, Paraguai, Peru e Brasil (Chase, 2009). No Brasil ocorrem 25 espécies (15 endêmicas), nos biomas Amazônia, Cerrado e Mata Atlântica. No bioma Cerrado ocorrem 10 espécies e para o Distrito Federal são citadas duas, Notylia hemitricha Barb.Rodr. e Notylia lyrata S.Moore (Barros et al., 2015).

Diferentemente das espécies do gênero mais próximo, Macroclinium, as espécies de Notylia possuem racemos pendentes com flores mais laxas. Quanto à polinização é também realizada por machos de abelhas Euglossini que coletam fragrâncias florais (Chase, 2009; Neubig et al., 2012). 


\section{Bibliografia:}

Barros, F. de; Vinhos, F.; Rodrigues, V.T.; Barberena, F.F.V.A.; Fraga, C.N.; Pessoa, E.M.; Forster, W.; Menini Neto, L. 2015 Orchidaceae. In: Lista de Espécies da Flora do Brasil. Jardim Botânico do Rio de Janeiro. http://floradobrasil.jbrj.gov.br/jabot/floradobrasil/FB19976 <acesso em: 24/02/2015>

Chase, M.W. 2009. Subtribe Oncidiinae. Pag. 211-391. In: Pridgeon, A.M.; Cribb, P.J.; Chase, M.W. \& Rasmussen, F.N. Genera Orchidacearum. Epidendroideae (Part Two). V. 5. Oxford. University Press.

Neubig, K.M., W. M. Whitten, N. H. Williams, M. A. Blanco, L. Endara, J. G. Burleigh, K. Silvera, J. C. Cushman, \& M. W. Chase. 2012. Generic recircumscriptions of Oncidiinae (Orchidaceae: Cymbidieae) based on maximum likelihood analysis of combined DNA datasets. Botanical Journal of the Linnean Society 168: 117-146.

10.1. Notylia lyrata S.Moore. Trans. Linn. Soc. London, Bot. 4: 477 (1895).

Fig. 2. G; 5. B.

Pseudobulbos verdes, 0,9-3,0 x 0,2-0,6 cm, protegidos lateralmente por bainhas foliosas, persistentes e articuladas, 3,0-8,1 cm, encimados por 1 folha. Folhas sésseis, elípticas a estreitamente obovadas, bases atenuadas, ápices obtusos, 4,4-12,0 x 0,8-2,6 $\mathrm{cm}$. Inflorescência 10-90 ou mais flores, 5,0-20,0 $\mathrm{cm}$ de comp. total. Flores pediceladas, pedicelos 3,0-5,0 mm de comp. Sépalas similares, estreitamente elípticas a lineares, bases atenuadas, margens inteiras, ápices agudos, membranáceas, amarelas, sépala dorsal 4,0-5,0 x 0,6-1,5 mm, sépalas laterais 2/3 adnatas, 3,0-6,5 x 0,3-1,0 mm. Pétalas elípticas a lineares, bases atenuadas, margens inteiras, ápices agudos, membranáceas, amarelo-esbranquiçadas com duas pintas basais alaranjadas, 3,5-6,0 x 0,7-1,1 mm. Labelo branco-amarelado, 3,0-5,0 x 1,4-2,5 mm; base unguiculada, ápice agudo a obtuso, amarelada, 0,3-0,8 x 0,2-0,5 mm, lobo médio-apical oval-lanceolado, esbranquiçado, 2,5-4,0 x 1,5-2,5 mm; região do disco com calo carnoso, alongado, carenado. Coluna 1,5-2,5 x 0,3-1,0 mm, castanha. Fruto 8,0-9,0 x 4,0-5,0 mm, oblongo. 
Notylia lyrata ocorre no Paraguai e Brasil (WCSP, 2014). No Brasil se distribui no Distrito Federal e nos estados do Amazonas, Bahia, Ceará, Espírito Santo, Goiás, Maranhão, Mato Grosso, Minas Gerais, Pará, Paraíba, Paraná, Pernambuco, Rio de Janeiro, Rio Grande do Sul, Santa Catarina, São Paulo e Tocantins, principalmente nos biomas Amazônia, Cerrado e Mata Atlântica. Vegeta em Mata Ciliar ou Mata de Galeria, Floresta de Terra Firme, Mata Seca Semidecídua, Floresta Ombrófila (= Floresta Pluvial) e Restinga (Barros et al., 2015). No Distrito Federal vegeta em Mata Ciliar e Mata de Galeria, florescendo nos meses junho a setembro, e frutificando nos meses de outubro a novembro.

Material selecionado: BR-020, Fazenda Rio Preto, XI.1982, Ramos, A.E. 166 (CEN). Caminho da FERCAL, próximo ao Rio Maranhão, VIII.1979, Bianchetti, L. 432 (HEPH). Fazenda Água Limpa, UnB, 1550’S, 4800’O, VI.1988, Grupo da $C R G F$, s.n. (CEN15122). IBGE, Córrego Roncador, 1557'S, 4752’O, VIII.1989, Azevedo, M.L.M. 297 (IBGE). Núcleo Rural Jardim II, Margem direita do Rio Preto, $16^{\circ} 00^{\prime}$ S, $47^{\circ} 22^{\prime} \mathrm{O}$, X.2002, Rezende, J.M. 630 (CEN). Parque Nacional de Brasília, Mata córrego do acampamento, 1545’39'S, 4758'40”W, VI.2014, Queiroz, V.V. \& Lima, J.H. 13 (UB). Santuário Ecológico do Riacho Fundo, 1551'S, 4757'O, X.1994, Oliveira, R.S. 8 (UB).

Notylia hemitricha Barb.Rodr. é citada para o Distrito Federal pela Lista de Espécies da Flora do Brasil (Barros et al., 2015). Os materiais testemunhos citados pela referida lista [Ghillany, A., s.n., HB 68909; Klein, R.M., Bresolin, A., 8585, FLOR, (SC); Fraga, C.N., 127, MBML, (ES)], não são do Distrito Federal. Como nenhum material que testemunhe a suposta ocorrência tenha sido localizado, acreditamos tratarse de erro na identificação quando consideramos a similaridade morfológica entre $N$. hemitricha e N. lyrata (que de fato ocorre).

11. Plectrophora H.Focke, Tijdschr. Nat. Wetensch., 1, 212 (1848).

Ervas epífitas. Rizoma curto entre os caules secundários. Caules secundários intumescidos ou não em pseudobulbos, se presentes então reduzidos, ancipitados, encimados por 1-folha. Folhas ensiformes, flabeliformes, unifaciais, carnosas, 
superfícies lisas, articuladas, verdes. Inflorescência lateral, tipo racemo, comprimento menor que as folhas, geralmente uniflora. Flores ressupinadas, pouco vistosas, esverdeadas, brancas ou amarelas, às vezes com mancha laranja-avermelhada no labelo. Sépalas dorsais livres, as laterais fundidas na base envolvendo esporão nectarífero. Pétalas livres. Labelo inteiro a levemente bilobado, margens curvadas sobre a coluna, calcarado, base do labelo inserido perpendicularmente na base da coluna, base prolongada formando esporão protegido pelas sépalas laterais; região do disco ecaloso ou com par de cristas na base. Coluna não alada, fracamente arqueada; ausência de tábula infraestigmática; clinândrio pouco desenvolvido, liso. Fruto cápsula elipsóide, 3alada a fortemente 3-angulada; frutos maduros com ápice dos carpelos unidos.

Gênero estabelecido pelo botânico holandês Hendrik Charles Focke, em 1848, em alusão à presença de esporão nas flores (Chase, 2009).

O gênero possui cerca de nove espécies distribuídas na Costa Rica, Panamá, Venezuela, Colômbia, Equador, Peru, Bolívia e Brasil tipo (Chase, 2009). No Brasil ocorrem cinco espécies (três endêmicas) nos biomas Amazônia e Cerrado. No bioma Cerrado existem três espécies e no Distrito Federal ocorre uma espécie, Plectrophora edwallii Cogn. (Barros et al., 2015).

Não existem informações sobre mecanismos de polinização e de polinizadores para espécies de Plectrophora. Entretanto, as espécies de Plectrophora são plantas pequenas com flores grandes e apresentam o labelo em forma de funil e um esporão formado pelas sépalas laterais, porém sem glândulas produtoras de néctar (Neubig et al., 2012). Chase (2009), citando Dodson (2003), considera a relativa semelhança das flores de Plectrophora com as flores de Trichocentrum s.s. e acredita que esses dois gêneros apresentem a mesma síndrome de polinização, ou seja, intui que Plectrophora possa ser polinizada por machos de abelhas Euglossini que coletam fragrâncias como Trichocentrum. Segundo Neubig et al. (2012), provavelmetne as flores sejam polinizadas por engano, por insetos que forrageiam néctar e possuem língua longa.

\section{Bibliografia:}

Barros, F. de; Vinhos, F.; Rodrigues, V.T.; Barberena, F.F.V.A.; Fraga, C.N.; Pessoa, E.M.; Forster, W.; Menini Neto, L. 2015 Orchidaceae. In: Lista de Espécies da Flora 
do Brasil. Jardim Botânico do Rio de Janeiro. http://floradobrasil.jbrj.gov.br/jabot/floradobrasil/FB19976 <acesso em: 24/02/2015>

Chase, M.W. 2009. Subtribe Oncidiinae. Pag. 211-391. In: Pridgeon, A.M.; Cribb, P.J.; Chase, M.W. \& Rasmussen, F.N. Genera Orchidacearum. Epidendroideae (Part Two). V. 5. Oxford. University Press.

Dodson CH. 2003. Native Ecuadorian Orchids, Volume 5. The Dodson Trust: Sarasota, Florida, USA.

Neubig, K.M., W. M. Whitten, N. H. Williams, M. A. Blanco, L. Endara, J. G. Burleigh, K. Silvera, J. C. Cushman, \& M. W. Chase. 2012. Generic recircumscriptions of Oncidiinae (Orchidaceae: Cymbidieae) based on maximum likelihood analysis of combined DNA datasets. Botanical Journal of the Linnean Society 168: 117-146.

11.1. Plectrophora edwallii Cogn. Fl. Bras. 3(6): 580 (1906).

Fig. 2. C-D; 5. B.

Pseudobulbos largo elípticos a suborbiculares, extremamente ancipitados verdeamarelados, 9,0 x 7,0 mm, protegidos por bainhas articuladas e persistentes 4,9-8,0 cm. Folhas elípticas a estreitamente ovais, base truncadas, ápices agudos, verdes, 6,2-12,4 x 0,6-1,0 cm. Inflorescência curta, até 3 flores abrindo-se sucessivamente, $4,9 \mathrm{~cm}$ de comp. total; Flores pediceladas, pedicelos 1,1-1,9 cm. Sépalas semelhantes, ovais, bases atenuadas, margens inteiras, ápices agudos, membranáceas, amarelo-pálidas, sépala dorsal 10,0 x 3,0 mm; sépalas laterais 8,0-10,0 x 2,0 mm. Pétalas elípticas, bases atenuadas, margens inteiras, ápices agudos, membranáceas, amarelas, 11,0 x 5,0 mm. Labelo obovado, margem eroso, ápice obtuso, amarelo com estrias mais escuras acompanhando as nervuras, $13,0 \times 8,0 \mathrm{~cm}$; esporão 9,0 x 1,0-2,0 mm. Coluna 3,0 x 1,0 mm. Fruto 2,0 x 1,5 cm, elipsóide.

Plectrophora edwallii ocorre na Bolívia, Peru e Brasil (Tropicos, 2014). No Brasil se distribui no Distrito Federal e nos estados do Goiás, Mato Grosso, Minas 
Gerais e Pará, nas regiões Centro Oeste, Norte e Sudeste, e nos biomas Amazônia e Cerrado. Vegeta em Mata Ciliar ou Mata de Galeria, Floresta de Terra Firme, Mata Seca Semidecídua (Barros et al., 2015). No Distrito Federal vegeta em Mata Ciliar sobre afloramento calcário, Mata mesofítica semidecídua (Mata Seca Semidecídua), e floresce nos meses de abril e agosto, e frutificando no mês de a partir do mês de abril.

Material examinado: FERCAL, Entrada da gruta da Pedra Encantada, IV.2006, Rezende, J.M. 1071 (CEN). Margens do Rio Preto, Divisa do DF com MG, VIII.1963, Heringer, E.P. 9186 (UB).

Material adicional examinado: GOIÁS. Formosa, Salto do Itiquira, 15²2’02,6”S, 47²7'10,8”W, XII.2014, Queiroz, V.V. et al., 22 (UB, CEN). Niquelândia, Áreas sobre o trecho final do rio Tocantinzinho, XI.1996, Walter, B.M.T. 3615 (CEN).

12. Rodriguezia Ruiz \& Pav., Fl. Peruv. et Chil. Prodr., 115, t. 25 (1794).

Ervas epífitas. Rizoma curto a extremamente longo entre os caules secundários. Caules secundários intumescidos em pseudobulbos, alongados a orbiculados, encimados por 14 folhas. Folhas bifaciais, conduplicadas, coriáceas, articuladas, verdes. Inflorescência lateral, geralmente tipo racemo, geralmente maior que as folhas, pauci a multiflora. Flores ressupinadas, vistosas, amarelas, rosas, carmins, muitas vezes com marcas vermelhas e amarelas nas sépalas e labelo. Sépala dorsal livre; base das sépalas laterais fundidas envolvendo mento nectarífero. Pétalas livres. Labelo inteiro, oblanceolado, base do labelo inserido perpendicularmente na base da coluna, base prolongada formando pequeno mento ou não, ápice dilatado, geralmente emarginado; região do disco com uma ou mais carenas ou cristas. Coluna com par de braços desenvolvidos no ápice e par de braços menores ladeando o estigma, base levemente projetada secretando néctar dentro do mento, ausência de tábula infraestigmática, clinândrio pouco desenvolvido, liso. Fruto cápsula elíptica a ovóide, não a levemente 3-angulada; frutos maduros com ápice dos carpelos unidos. 
Gênero estabelecido pelos botânicos espanhóis Hipólito Ruiz López e José Antonio Pavón Jiménez, em 1794, em homenagem a Antonio Manuel Rodriguez de Vera (1780-1846), botânico espanhol e farmacêutico da corte espanhola (Chase, 2009).

O gênero possui cerca de 48 espécies distribuídas a partir do México, América Central, Colômbia, Venezuela, Argentina, Bolívia, Peru e Brasil (Chase, 2009). No Brasil ocorrem cerca de 23 espécies (17 endêmicas) nos biomas Amazônia, Cerrado e Mata Atlântica. No bioma Cerrado ocorrem quatro espécies e no Distrito Federal ocorre Rodriguezia decora (Lem.) Rchb.f.

As espécies de Rodriguezia possuem flores vistosas, relativamente grandes e de cores vivas, ao contrário das demais espécies "twig" que ficam sobre as copas das árvores, na camada mais externa e recebem alta luminosidade e radiação. O labelo é, muitas vezes, relativamente grande e plano e as sépalas laterais são fundidas formando um esporão nectarífico alongado ou apenas um pequeno mento. Em algumas espécies, as duas projeções da base da coluna secretam néctar para dentro do esporão. Neubig et al. (2012), baseados no trabalho de Chase (2009), apontam que a espécie brasileira Rodriguezia decora, não se enquadra nas características compartilhadas pela maioria das espécies do gênero, como por exemplo, longo rizoma entre os pseudobulbos e ausência de esporão alongado. Segundo Dodson (1965), para as espécies de Rodriguezia que produzem néctar, exceto $R$. decora, são registrados beija-flores, borboletas e abelhas que forrageiam em busca de néctar como polinizadores.

\section{Bibliografia:}

Barros, F. de; Vinhos, F.; Rodrigues, V.T.; Barberena, F.F.V.A.; Fraga, C.N.; Pessoa, E.M.; Forster, W.; Menini Neto, L. 2015 Orchidaceae. In: Lista de Espécies da Flora do Brasil. Jardim Botânico do Rio de Janeiro. http://floradobrasil.jbrj.gov.br/jabot/floradobrasil/FB19976 <acesso em: 24/02/2015>

Chase, M.W. 2009. Subtribe Oncidiinae. Pag. 211-391. In: Pridgeon, A.M.; Cribb, P.J.; Chase, M.W. \& Rasmussen, F.N. Genera Orchidacearum. Epidendroideae (Part Two). V. 5. Oxford. University Press. 
Dodson C.H. 1965. Agentes de polinización y su influencia sobre la evolución de la familia Orquidacea. Universidad Nacional de la Amazonía Peruana, Instituto General de Investigación. Iquitos, Peru.

Neubig, K.M., W.M. Whitten, N.H. Williams, M.A. Blanco, L. Endara, J.G. Burleigh, K. Silvera, J.C. Cushman, \& M.W. Chase. 2012. Generic recircumscriptions of Oncidiinae (Orchidaceae: Cymbidieae) based on maximum likelihood analysis of combined DNA datasets. Botanical Journal of the Linnean Society 168: 117-146.

\subsection{Rodriguezia decora Rchb. f. Bot. Zeitung (Berlin) 10: 771 (1852).}

Fig. 3. A-C; 5. C

Rizoma longo entre os pseudobulbos, 3,0-19,5 cm. Pseudobulbos elípticos a obovados, castanho-esverdeados, 1,0-2,5 x 0,4-1,7 cm, protegidos lateralmente por bainhas foliares articuladas e persistentes, 4,2-12,7 cm, encimados por 1 folha. Folhas sésseis, estreitamente ovaladas a elípticas, base atenuada, ápice agudo, rotundo a mucronado, coriáceas, 2,9-13,0 x 0,7-2,3 cm. Inflorescência 5-15 ou mais flores, 12,0-29,0 cm comp. tota. Flores pediceladas, pedicelos $0,8-1,1 \mathrm{~cm}$ de comp. Sépalas similares, elípticas, bases atenuada, margens inteiras, ápices agudos, membranáceas, brancas ou levemente róseas pintalgadas de vinho, sépala dorsal 0,8-1,7 x 0,3-0,5 cm, sépalas laterais $2 / 3$ adnatas, 1,3-1,9 x 0,1-0,3 cm, encobrindo pequeno mento na base do labelo. Pétalas ovaladas, bases atenuadas, margens inteiras, ápices obtusos, membranáceas, brancas pintalgadas de vinho com leve coloração rósea no centro, 1,3-1,8 x 0,3-0,8 cm. Labelo base atenuada, unguiculada, presença de pequeno mento, parte mediana pintalgada de vinho, parte apical dilatada, rotundado-reniforme, ápice emarginado, branca sem pintas, 1,6-3,0 x 1,0-1,9 cm; região do disco 2-lamelado, serreado. Coluna 4,0-7,0 x 1,0 mm, castanho escura, 4 braços apicais, ligulados, braços posteriores menores, 1,0-2,0 mm de comp., braços anteriores maiores, 3,0-4,0 $\mathrm{mm}$ de comp. Fruto não visto.

Rodriguezia decora ocorre no Paraguai, Argentina e Brasil (WCSP, 2014). No Brasil se distribui no Distrito Federal e nos estados do Paraná, Rio Grande do Sul, Santa Catarina e São Paulo, nas regiões Centro Oeste, Sudeste e Sul, e nos biomas do Cerrado 
e Mata Atlântica. Vegeta em Mata Ciliar ou Mata de Galeria, Floresta Mata Seca Decídua, Mata Seca Semidecídua, Floresta Ombrófila (= Floresta Pluvial) (Barros et al., 2015). No Distrito Federal vegeta em ambientes de Mata de Galeria Inundável e floresce nos meses de dezembro a março.

Material selecionado: Colégio Agrícola, XII.2003, Salles, A.E.H. et al., 2899 (HEPH). Fazenda Sucupira, Mata do Riacho Fundo, III.2000, Batista, J.A.N. 1052 (CEN). Mata entre o Guará e o Setor de Indústria, II.1981, Chagas, F. 369 (IBGE). Parque Nacional de Brasília, Córrego do Acampamento, III.1983, Ramos, A.E. 234 (CEN, HEPH). Parque Zoobotânico, III.1961, Heringer, E.P. 8063 (UB). Reserva Ecológica do Guará, II.2001, Miranda, Z.J.G. 71 (CEN). Reserva Ecológica do IBGE, Córrego Taquara, 1556’S, 4755’O, III.1994, Walter, B.M.T. 2089 (CEN).

Rodriguezia brachystachys Rchb.f. \& Warm também é citada para o Distrito Federal (Barros et al., 2015), mas não foi encontrado nenhum voucher para a região e por esse motivo foi retirada da atualização.

Rodriguezia decora var. lactea L.C.Menezes, também é citada para o Distrito Federal (Menezes 1995). Em exame do material tipo (Brasília, Mata Alagada do Guará. Sem data. Menezes, L.C. 36, UB) foi observado à inexistência de flores e de inflorescências. Segundo informações retiradas da Lista das Espécies da Flora do Brasil (2015) Rodriguezia decora var. lactea L.C.Menezes é sinônimo de Rodriguezia decora Rchb. f.

Apenas para ilustração quanto à categoria infra-específica, Barros \& Batista (2004) consideram que essa categoria seria melhor tratada como forma e não como variedade (Rodriguezia decora f. lactea (L.C.Menezes) F.Barros \& J.A.N.Bat.).

13. Sanderella Kuntze, Rev. Gen. Pl., 2, 649 (1891).

Ervas epífitas. Rizoma curto entre os caules secundários. Caules secundários intumescidos em pseudobulbos, elípticas, ancipitados, encimados por 1 folha. Folhas conduplicadas, bifaciais, coriáceas, articuladas, verdes ou arroxeadas. Inflorescência lateral, tipo racemo, menor ou do mesmo comprimento das folhas, multiflora. Flores ressupinadas, pequenas e pouco vistosas, branco-esverdeadas com manchas marrons 
avermelhadas. Sépala dorsal livre; sépalas laterais fundidas na maior parte. Pétalas livres. Labelo inteiro, oblongo a pandurado, ecalcarado, base do labelo inserido perpendicularmente na base da coluna, ápice não emarginado; região do disco com calo elevado. Coluna alada, pequenas projeções ladeando o estigma, ápice com discretos braços projetados para frente, ausência de tábula infraestigmática, clinândrio pouco desenvolvido, liso. Fruto cápsula elipsóide, não a levemente 3-angulada; frutos maduros com ápice dos carpelos unidos.

Gênero estabelecido pelo botânico alemão Carl Ernst Otto Kuntze, em 1891, em homenagem ao britânico Henry F. C. Sander (1847-1920), especialista em orquídeas, fundador da F. Sander \& Company e autor da primeira lista de híbridos de orquídeas (Chase, 2009).

O gênero possui duas espécies distribuídas na Bolívia, Argentina e Brasil. No Brasil as espécies ocorrem nos biomas Cerrado e Mata Atlântica (Chase, 2009). No bioma Cerrado e Distrito Federal ocorre apenas Sanderella discolor (Barb.Rodr.) Cogn. (Barros et al., 2015).

Singer e Cocucci (1999) relataram a visita de abelhas e vespas em Capanemia e comentam que Cássio van den Berg (em comunicação pessoal) faz referência sobre a similaridade morfológica entre Sanderella e Capanemia e a possibilidade das duas espécies possuírem os mesmos polinizadores.

\section{Bibliografia:}

Barros, F. de; Vinhos, F.; Rodrigues, V.T.; Barberena, F.F.V.A.; Fraga, C.N.; Pessoa, E.M.; Forster, W.; Menini Neto, L. 2015 Orchidaceae. In: Lista de Espécies da Flora do Brasil. Jardim Botânico do Rio de Janeiro. http://floradobrasil.jbrj.gov.br/jabot/floradobrasil/FB19976 <acesso em: 05/10/2014>

Chase, M.W. 2009. Subtribe Oncidiinae. Pag. 211-391. In: Pridgeon, A.M.; Cribb, P.J.; Chase, M.W. \& Rasmussen, F.N. Genera Orchidacearum. Epidendroideae (Part Two). V. 5. Oxford. University Press.

Singer, R.B. \& Cocucci, A.A. 1999. Pollination mechanisms in four sympatric southern Brazilian Epidendroideae orchids. Lindleyana 14: 47-56. 
13.1. Sanderella discolor (Barb.Rodr.) Cogn. Fl. Bras. 3(6): 239 (1905).

Fig. 5-C.

Pseudobulbos verdes, 5,0-12,0 x 1,0-5,0 mm, protegidos lateralmente por bainhas paleáceas, persistentes, 0,6-2,7 cm. Folhas sésseis, elípticas a lanceoladas, bases atenuadas, ápices agudos, coriáceas, verde escuras, 2,4-7,7 x 0,3-1,0 cm. Inflorescência 5-19 flores, 1,5-8 cm de comp. total. Flores pediceladas, pedicelos 1,0-4,0 mm. Sépalas similares, levemente obovadas, bases estreitadas, margens inteiras, ápices agudos, membranáceas, esbranquiçadas com as bases vináceas, sépala dorsal 2,0-3,0 x 1,0-2,0 $\mathrm{mm}$, sépala lateral 213 adnatas, 2,0-3,0 x 1,0-2,0 $\mathrm{mm}$. Pétalas obovadas, bases truncadas, margens inteiras, ápices agudos, membranáceas, esbranquiçada, 2,0-3,0 x 1,0 mm. Labelo pandurado, ápice obtuso, reflexo, levemente acuminado, 2,0-3,0 x 0,6-1,0 mm; região do disco com calo bilamelado. Coluna 1,0-1,5 x 0,3-0,7 mm, castanha. Fruto não visto.

Sanderella discolor ocorre na Argentina, Bolívia e Brasil (Tropicos, 2014). No Brasil se distribui Distrito Federal e nos estados do Goiás, Minas Gerais, Paraná, Rio Grande do Sul e São Paulo, nas regiões Centro Oeste, Sudeste e Sul, nos biomas Cerrado e Mata Atlântica. Vegeta em fitofisionomias que geralmente apresentam alto índice de umidade, como Mata Ciliar ou Mata de Galeria, Mata Seca Semidecídua, Floresta Ombrófila (= Floresta Pluvial) (Barros et al., 2015). No Distrito Federal ocorre em Mata Ciliar, Mata de Galeria Inundável, e floresce nos meses de maio e junho.

Material selecionado: Córrego Acampamento, V.1991, Batista, J.A.N. 199 (CEN). Fazenda Sucupira, VI.1995, Assis, M.C. 230 (CEN). Margem do Riacho Fundo, Fundação Zoobotânica, s.d., Heringer, E.P. s.n. (UB8333). Reserva Ecológica do Guará, XI.2003, Batista, J.A.N. 1454 (CEN). Sobradinho dos Melos, VI.2005, Salles, A.H. 3787 (HEPH). 
14. Trichocentrum Poepp. \& Endl., Nov. Gen. Spec. Pl., 2, 11, t. 115 (1836). "Strictu sensu”

Ervas epífitas. Rizoma curto entre os caules secundários. Caules secundários intumescidos em pequenos (reduzidos) pseudobulbos, ovóides a cilíndricos, encimados por 1 folha. Folhas conduplicadas, bifaciais, carnosas, articuladas, verdes, geralmente pintalgadas de roxo. Inflorescência lateral, tipo racemo ou panícula, comprimento menor que as folhas, pauciflora. Flores ressupinadas, vistosas, combinação de cores marrom, rosa, roxo, amarelo e branco. Sépalas e pétalas livres e similares entre si. Labelo inteiro a trilobado, calcarado, base do labelo inserido perpendicularmente na base da coluna, lobo apical bilobado, margens inteiras; região do disco com calo tuberculoso ou com carenas ou lâminas longitudinais. Coluna não alada, aurículas ou braços apicais desenvolvidos, petalóides, ausência de tábula infraestigmática, clinândrio pouco desenvolvido, liso. Fruto cápsula elipsóide, geralmente não 3-angulada, ocasionalmente alada; frutos maduros com ápice dos carpelos unidos.

Gênero estabelecido pelo botânico alemão Eduard Friedrich Poeppig e pelo botânico húngaro Stephan Friedrich Ladislaus Endlicher, em 1836, em alusão à presença de tricomas ou papilas nas paredes internas do esporão (Pupulin, 1995; Chase, 2009).

O gênero possui cerca de 30 espécies distribuídas em toda a região neotropical, desde o sul da Flórida, México, América Central, Caribe, Argentina, Uruguai, Paraguai, Peru e Brasil (Pupulin, 1995; Chase, 2009). No Brasil ocorrem cinco espécies (duas endêmicas) nos biomas Amazônia, Cerrado e Mata Atlântica. No Cerrado ocorrem duas espécies e no Distrito Federal ocorre apenas Trichocentrum albococcineum Linden (Barros et al., 2015).

Chase (2009) comenta os relatos de van der Pijl \& Dodson (1966) e de Roubik \& Ackerman (1987) sobre as espécies de Trichocentrum s.s. apresentarem a síndrome de polinização por abelhas Euglossini. Em muitos casos, espécies de Trichocentrum apresentam um nectário não funcional, ou seja, um esporão sem a presença de néctar e esse fato pode estar associado a duas estratégias de polinização: atrair machos de Euglossini que coletam fragrância, e fêmeas que forrageiam em busca de néctar e são enganadas pela presença do esporão. 


\section{Bibliografia:}

Barros, F. de; Vinhos, F.; Rodrigues, V.T.; Barberena, F.F.V.A.; Fraga, C.N.; Pessoa, E.M.; Forster, W.; Menini Neto, L. 2014. Orchidaceae. In: Lista de Espécies da Flora do Brasil. Jardim Botânico do Rio de Janeiro. http://floradobrasil.jbrj.gov.br/jabot/floradobrasil/FB19976 <acesso em: 24/02/2015>

Chase, M.W. 2009. Subtribe Oncidiinae. Pag. 211-391. In: Pridgeon, A.M.; Cribb, P.J.; Chase, M.W. \& Rasmussen, F.N. Genera Orchidacearum. Epidendroideae (Part Two). V. 5. Oxford. University Press.

Pupulin, F. 1995. A revision of the genus Trichocentrum (Orchidaceae: Oncidiinae). Lindleyana 10: 183-210.

Roubik, D.W. \& Ackerman, J.D. 1987. Long-term ecology of euglossine orchid-bees (Apidae: Euglossini) in Panama. Oecologia 73:321-333.

Van der Pijl L.; Dodson C.H. 1966. Orchid Flowers: Their Pollination and Evolution. University of Miami Press: Coral Gables, Florida, USA.

14.1. Trichocentrum albococcineum Linden. Ann. Hort. Belge Étrangère 15: 103 (1865).

Fig. 3. G-H; 5. D

Pseudobulbos verdes, 0,5-0,7 x 0,2-0,4 cm. Folhas sésseis, elípticas a ovadas, base atenuada, ápice agudo, 6,4-13,6 x 1,2-1,8 cm. Inflorescência tipo racemo, 1-2 flores, 4,0-4,5 cm de comp. total. Flores pediceladas, pedicelos 3,0-4,0 cm. Sépalas obovadas, base levemente estreitada, ápice agudo-acuminado, membranáceas, verdeamarronzadas, sépala dorsal $1,9 \times 0,9 \mathrm{~cm}$, sépala lateral 1,9-2,2 x 0,5-0,7 cm; pétalas ápice obtuso, 1,8-1,9 x 0,7-0,9 cm. Labelo pandurado, branco com duas faixas laterais coccíneas, 2,8-3,4 x 2,0-2,2 cm; base estreitada, 9,0 mm de comp., ápice emarginado, esporão 6,0-8,0 mm de comp.; região do disco com calo lamelado. Coluna 0,7 x 0,4 $\mathrm{cm}$, castanho escuro. Fruto não visto. 
Trichocentrum albococcineum ocorre na Bolívia, Peru e Brasil (Tropicos, 2014). No Brasil se distribui no Distrito Federal e nos estados do Amazonas, Goiás, Mato Grosso, Mato Grosso do Sul, Pará e Rondônia, nas regiões Centro Oeste e Norte, e nos biomas Amazônia e Cerrado. Vegeta em Mata Ciliar ou Mata de Galeria, Floresta de Igapó, Floresta de Terra Firme, Mata Seca Semidecídua (Barros et al., 2015). No Distrito Federal vegeta em Mata de Galeria e floresce em fevereiro.

Material examinado: Estação Ecológica de Águas Emendadas, II.2014, Lima, J.H. 55 (UB).

Material adicional examinado: GOIÁS. Catalão, Fazenda Barra a $3 \mathrm{~km}$ de Davinopolis, s.d. Salles, A.H. et al., 2658 (HEPH).

15. Trichopilia Lindl. Bot. Reg., 22, t. 1863 (1836).

Ervas epífitas. Rizoma curto entre os caules secundários. Caules secundários intumescidos em pseudobulbos, teretes a lateralmente ancipitados, encimados por 1 folha. Folhas conduplicadas, bifaciais, carnosas a coriáceas, articuladas, verdes. Inflorescência lateral, tipo racemo, geralmente mais curta que as folhas, pauciflora. Flores ressupinadas, pequenas, geralmente brancas com pintas róseas. Sépalas e pétalas livres e similares entre si. Labelo inteiro, ecalcarado, base do labelo inserido perpendicularmente na base da coluna, margens basais curvadas sobre a coluna; região do disco com carenas próximas à base, às vezes papilosas. Coluna metade do comprimento do labelo, reta; ausência de tábula infraestigmática; clinândrio muito desenvolvido (comprimento acima da antera), lacerado. Fruto cápsula elíptica a ovóide, não a levemente 3-angulada; frutos maduros com ápice dos carpelos unidos.

Gênero estabelecido pelo botânico inglês John Lindley, em 1836, em alusão ao clinândrio que se apresenta lacerado, com textura de feltro, observada na espécie tipo (Chase, 2009).

O gênero possui cerca de 26 espécies distribuídas desde o México, América Central e Venezuela, Colômbia, Equador, Bolívia, Peru e Brasil (Chase, 2009). No Brasil ocorrem cinco espécies (duas endêmicas) nos biomas Amazônia, Cerrado e Mata Atlântica. No bioma Cerrado (Barros et al., 2015), e no Distrito Federal ocorre apenas 
uma espécie, Trichopilia brasiliensis Cogn., até então não citada para o Distrito Federal e registrada pela primeira vez no presente estudo.

As espécies de Trichopilia apresentam o labelo formando uma estrutura tubular, com a parte basal envolvendo a coluna, sugerindo um possível depósito de néctar (Neubig et al., 2012). Foi relatada por Dodson (1962) a polinização de abelhas machos de Euglossini coletores de fragrâncias. Algumas espécies de Cattleya e Sobralia possuem flores semelhantes, e também são visitadas por abelhas machos de Euglossini.

\section{Bibliografia:}

Barros, F. de; Vinhos, F.; Rodrigues, V.T.; Barberena, F.F.V.A.; Fraga, C.N.; Pessoa, E.M.; Forster, W.; Menini Neto, L. 2015 Orchidaceae. In: Lista de Espécies da Flora do Brasil. Jardim Botânico do Rio de Janeiro. http://floradobrasil.jbri.gov.br/jabot/floradobrasil/FB19976 <acesso em: 24/02/2015>

Chase, M.W. 2009. Subtribe Oncidiinae. Pag. 211-391. In: Pridgeon, A.M.; Cribb, P.J.; Chase, M.W. \& Rasmussen, F.N. Genera Orchidacearum. Epidendroideae (Part Two). V. 5. Oxford. University Press.

Dodson C.H. 1962. The importance of pollination in the evolution of the orchids of tropical America. American Orchid Society Bulletin 31: 525-534, 641-649, 731-735.

Neubig, K.M., W.M. Whitten, N.H. Williams, M.A. Blanco, L. Endara, J.G. Burleigh, K. Silvera, J.C. Cushman, \& M.W. Chase. 2012. Generic recircumscriptions of Oncidiinae (Orchidaceae: Cymbidieae) based on maximum likelihood analysis of combined DNA datasets. Botanical Journal of the Linnean Society 168: 117-146.

15.1.Trichopilia brasiliensis Cogn. Fl. Bras. 3(6): 580 (1906).

Fig. 3. D; 5. D

Pseudobulbos terete a subcilíndricos, verdes, 1,8-2,4 x 0,2-0,3 cm, protegidos por bainhas paleáceas, persistentes. Folhas sésseis, estreitamente elípticas a lineares, base truncada, ápice agudo, coriáceas, 16,0-18,0 x 0,7-0,8 cm. Inflorescência 1-5 flores, 3,0$6,0 \mathrm{~cm}$ comp. total. Flores pediceladas, pedicelo $0,9-1,1 \mathrm{~cm}$. Sépalas e pétalas 
elípticas, base estreitada, ápice acuminado, membranáceas, creme-esverdeadas com pequenas pintas arroxeadas, sépala dorsal 1,5-1,6 x 0,3-0,4 cm, sépala lateral 1,6-1,8 x 0,2-0,3 cm, pétalas 1,4-1,5 x 0,4 cm. Labelo largo elíptico, côncavo, base com duas protuberâncias ladeando a coluna, ápice agudo, coloração creme com maior quantidade de pintas roxas que as sépalas e pétalas e algumas vezes com carenas longitudinais escuras, 1,2-1,3 x 1,0-1,1 cm. Coluna 4,0-5,0 mm, castanha. Fruto não visto.

Ocorre exclusivamente no Brasil (WCSP, 2014). Distribui-se no Distrito Federal e nos estados Espírito Santo, Goiás, Maranhão, Mato Grosso, Pará e Rondônia, nas regiões Centro Oeste, Nordeste, Norte, Sudeste, e nos biomas Amazônia, Cerrado e Mata Atlântica. Vegeta em Mata Ciliar, Mata de Galeria, Floresta de Terra Firme, Floresta Ombrófila (= Floresta Pluvial) (Barros et al., 2015). No Distrito Federal vegeta em Mata Ciliar e floresce em no mês de janeiro.

Material examinado: DF-100, Sentido Formosa, Fazenda Manga, 1557’S, 47²2’O, I.2007, Santos, A.A. 1769 (CEN).

Material adicional examinado: GOIÁS. Pirenópolis, Santuário Ecológico do Vaga Fogo, II.1992, Bianchetti, L. 1238 (CEN).

\section{CONCLUSÃO}

A Subtribo Oncidiinae Benth. está bem representada no Distrito Federal, ocorrendo em vários ambientes protegidos, como reservas e unidades de conservação, além de ambientes não protegidos por legislação ambiental. A partir de resultados gerados pelo presente estudo, a Lista de Espécies da Flora do Brasil - Distrito Federal (Barros et al., 2015) deverá ser atualizada da seguinte forma: acréscimo de mais um gênero e duas espécies, Trichopilia brasiliensis Cogn. e Cohniella jonesiana (Rchb.f.) Christenson. A inclusão de Cohniella jonesiana, mesmo sem apresentar voucher para o DF, é justificada devido ao fato de ter sido citada por trabalhos anteriores (Pellizzaro et al., 2004; Bianchetti et al., 2005) e por apresentar registros em localidades próximas ao Distrito Federal, como Unaí - Minas Gerais, por exemplo. A supressão de Coppensia bifolia (Sims) Dumort e de Notylia hemitricha Barb. Rodr em decorrência de amostras erroneamente identificadas. Supressão da ocorrência de Rodriguezia brachystachys 
Rchb.f. \& Warm e de Gomesa foliosa (Hook.) Klotzsch \& Rchb.f. devido ao fato de não apresentarem vouchers e nem registros para proximidades do Distrito Federal. Desse modo, a representação da subtribo Oncidiinae, para a Flora do Distrito Federal, deverá ser atualizada para 15 gêneros e 18 espécies.

Percebe-se, hoje, a existência de duas abordagens taxonômicas diferentes para a subtribo Oncidiinae: a) uma abordagem que diz respeito à preferência ao reconhecimento de gêneros menores (Alatiglossum, Cohniella, Coppensia, Gomesa (s.s.), Lophiaris, Trichocentrum (s.s.), com delimitação mais estreita, com suporte monofilético e de fácil reconhecimento morfológico que, para as espécies de ocorrência no Distrito Federal, formam um conjunto de 15 gêneros e 18 espécies e, b) uma abordagem que diz respeito à preferência ao reconhecimento de gêneros maiores (Gomesa (s.1.) e Trichocentrum (s.1.), com delimitação mais abrangente ou ampla, com suporte monofilético, porém de difícil reconhecimento morfológico, dada a grande circunscrição morfológica que, para as espécies de ocorrência no Distrito Federal, formam um conjunto de 12 gêneros e 18 espécies.

Embora as duas abordagens sejam importantes e tratem do conhecimento da evolução dos gêneros e da circunscrição dos mesmos, é recomendável que, em estudos que tratem de diversidade ou riqueza para o Distrito Federal, seja explicitada qual abordagem foi utilizada, pois os resultados serão fortemente influenciados devido à grande variação no número de gêneros. 


\section{LISTA DE EXSICATAS}

Assis, M.C.: 230 (13.1); Augusto, M.M.: 1 (2.1); Azevedo, M.L.M.: 297 (10.1), 506 (5.2); Batista, J.A.N.: 54 (5.1), 118 (5.1), 199 (13.1), 205 (9.1), 261 (8.1), 300 (7.1), 306 (3.1), 337 (5.1), 800 (5.1), 878 (9.1), 935 (6.1), 1052 (12.1), 1101 (3.1), 1454 (13.1), s.n. CEN 60698 (8.1); Belém, R.P.: 1896 (5.1); Bianchetti, L.: 414 (8.1), 424 (13.1), 432 (10.1), 869 (1.2), 869-A (1.2), 869-B (1.1), 1161 (3.1), 1238 (15.1), 1239 (5.2), 1240 (9.1), 1460 (4.1), s.n. CEN 15096 (6.1); Chagas, F.: 369 (12.1); Faria, J.G.: 254 (5.2); Figueiredo, S.: 178-A,B (5.2), 195-A,B (5.2); Fonseca, M.L.: 1031 (1.2); Gomes, S.M.: 86 (5.2); Grupo da CRGF: s.n. CEN 15122 (10.1); Heringer, E.P.: 1831 (5.2), 3744 (5.1), 7380 (12.1), 7898 (9.1), 8063 (12.1), 8065 (5.2), 8447 (5.1), 9186 (11.1), 16751 (4.1), 18358 (11.1), 18462 (11.1), s.n. UB8333 (13.1); Ianhez, M.: 53 (6.1), 56 (6.1); Irwin, H.S.: 10607 (5.1); Lima, J.H.: 16 (4.1), 55 (14.1); Mendes, R.A.: 339 (3.1); Menezes, L.C.: 8 (5.2), 36 (12.1); Miranda, Z.J.G.: 71 (12.1), 82 (1.1); Nobrega, M.G.G.: 432-A,B (5.2), 1294 (6.1); Oliveira, R.S.: 8 (10.1), 16 (4.1), 28 (5.1), 64 (8.1); Pellizzaro, K.F.: 27 (1.2), 28 (6.1), 30 (3.1), 33 (8.1), 54 (8.1); Pereira Neto, M.: 515 (5.1); Pereira, B.A.S.: 2112 (7.1), 2271 (7.1); Pereira-Silva, G.: 5973 (9.1), 6947 (9.1), 7769 (7.1); Pinagé, E.R.: s.n. UB 14529 (5.1); Queiroz, V.V.: 13 (10.1), 15 (7.1), 18 (7.1), 22 (11.1); Ramos, A.E.: 166 (10.1), 234 (12.1), 577 (8.1), 1301 (8.1); Ratter, J.: 4293 (5.1); Rezende, J.M.: 255 (5.1), 630 (10.1), 662 (7.1), 1071 (11.1); Salles, A.E.H.: 3 (5.2), 1730 (5.1), 2658 (14.1), 2899 (12.1), 3761 (8.1), 3787 (13.1), s.n. CEN 026596 (5.1); Santos, A.A.: 398 (4.1), 1618 (2.1), 1698 (8.1), 1769 (15.1); Silva, J.S.: 318 (5.2); Soares, A.C.A.: s.n. HEPH 29268 (5.2); Sucre, D.: 607 (3.1), 647 (1.2); Valente, I.: 19 (4.1); Viana, P.L.: 2826 (3.2); Vieira, R.: 361 (6.1); Walter, B.M.T.: 2089 (12.1), 2091 (5.2), 3615 (11.1), 3774 (1.1). 


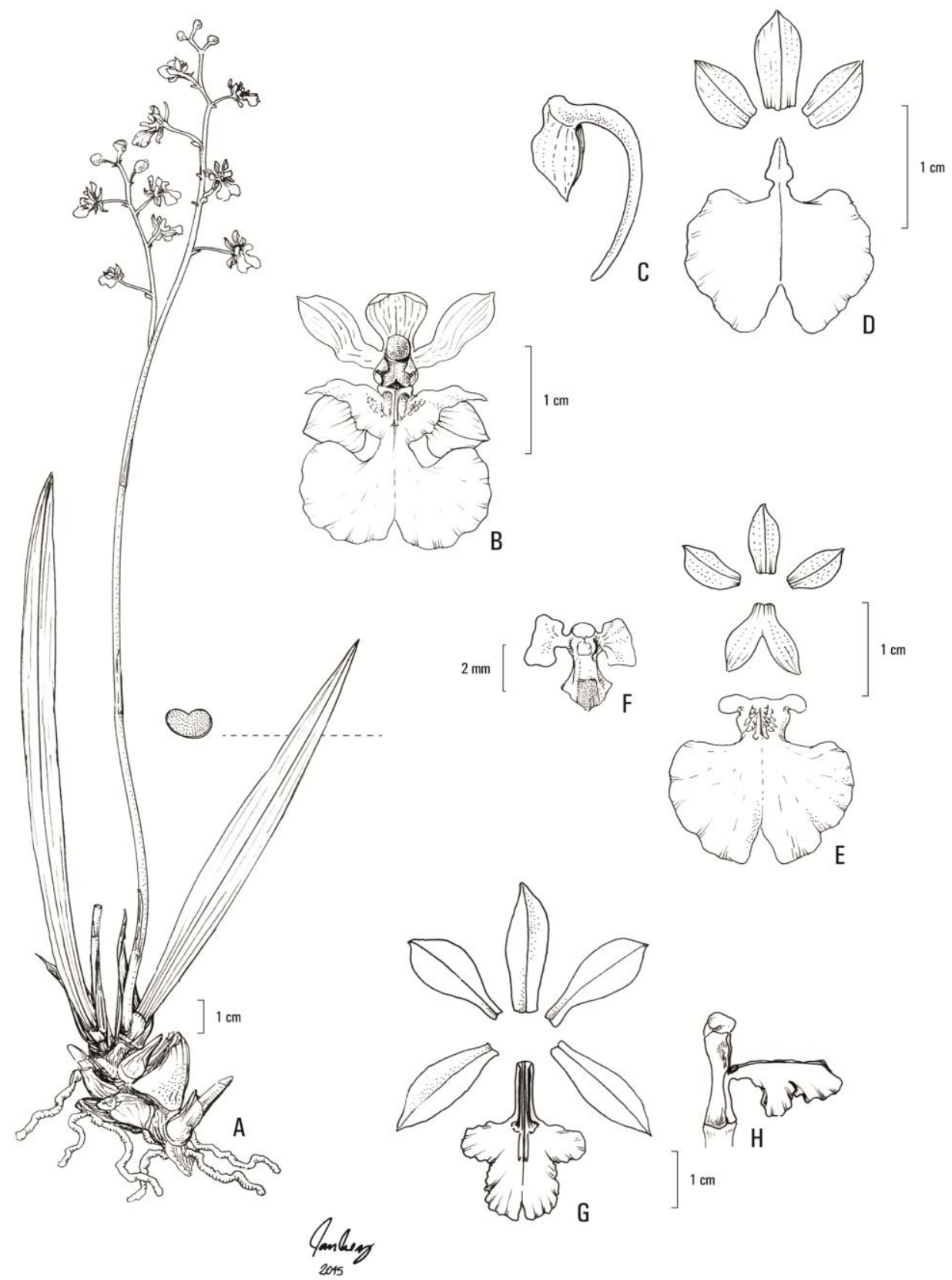

Figura 1. A-B. Cohniella cepula: A. Hábito; B. Flor; C-D. Comparettia coccinea: C. Sépalas laterais fundidas (esporão nectarífico); D. Flor aberta; E-F. Coppensia hydrophila: E. Flor aberta; F. Coluna, asas ou estelídios e tábula infraestigmática; G-H. Aspasia variegata: G. Flor aberta; H. labelo inserido na parte mediana da coluna. A-B. (Pellizzaro 30; C-D. Bianchetti 1460; E-F. Batista 337; G-H. Augusto 1.) 


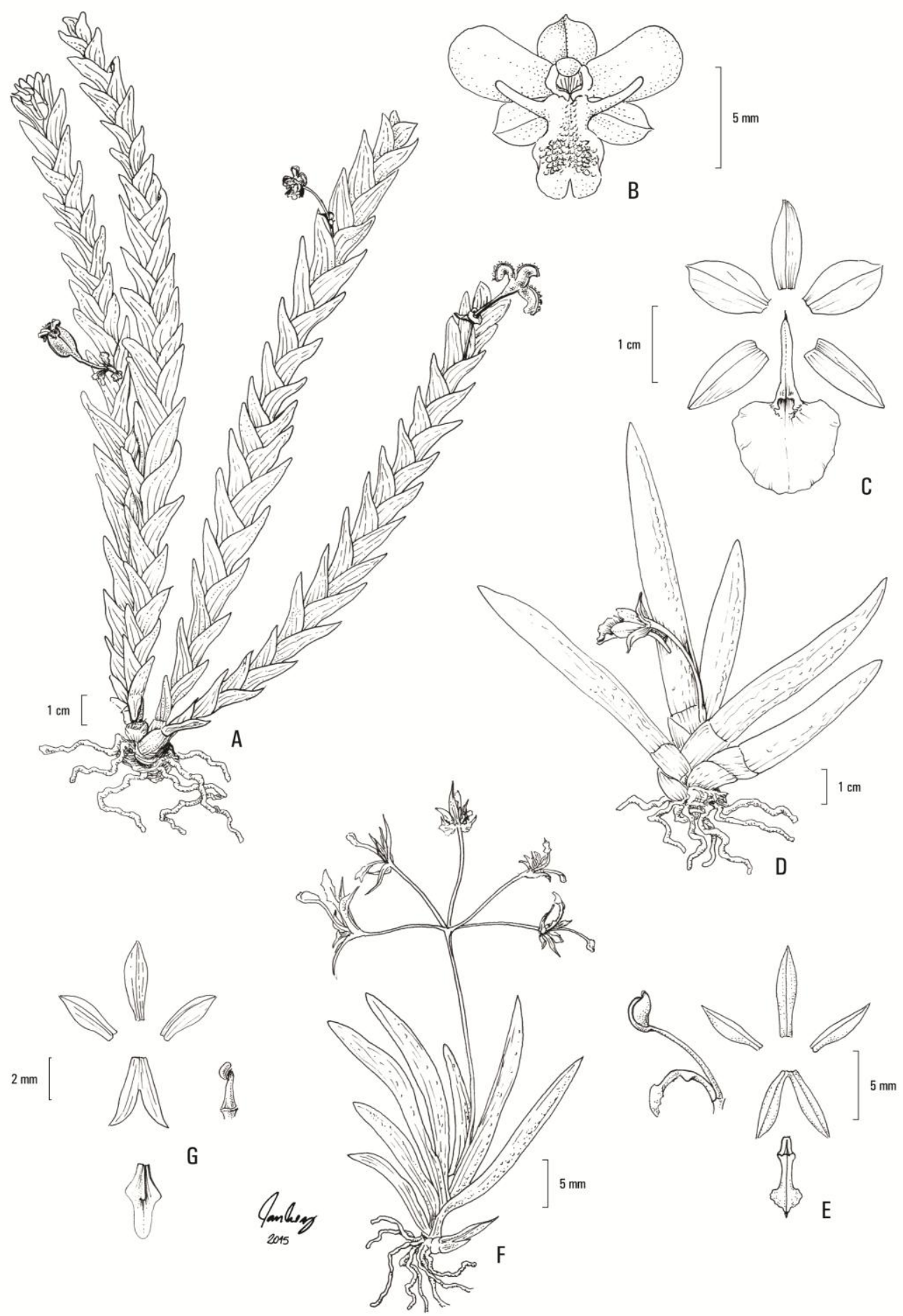

Figura 2. A-B. Lockhartia goyazensis: A. Hábito; B. Flor; C-D. Plectrophora edwallii: C. Flor aberta; D. Hábito; E-F. Macroclinium wullschlaegelianum: E. Flor aberta e coluna; F. Hábito; G. Notylia lyrata: Flor aberta e coluna. A-B. (Pereira 2271; C-D. Batista 95; E-F. Batista 878; G. Pereira-Silva 7575.) 


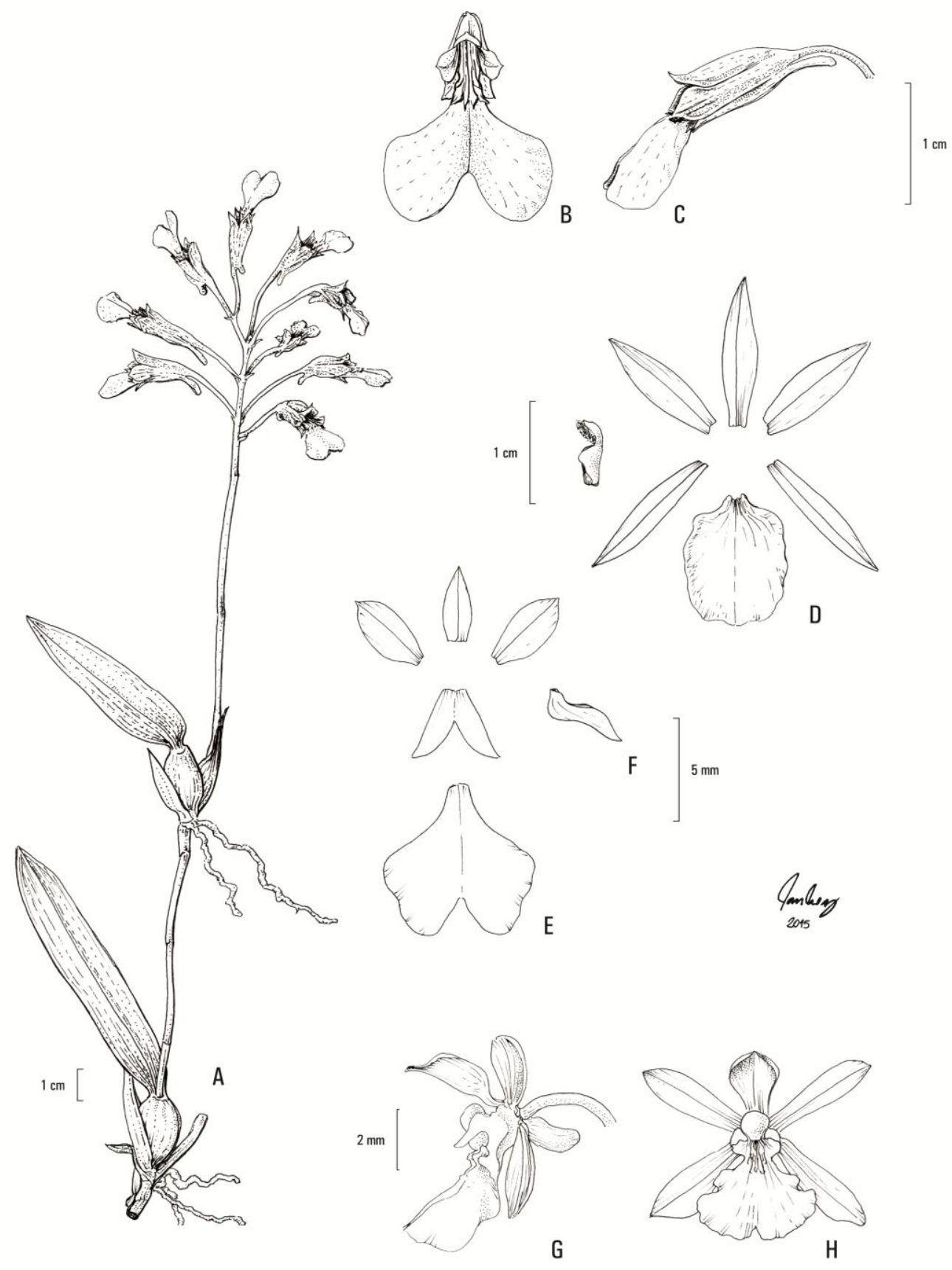

Figura 3. A-C. Rodriguezia decora: A. Hábito; B. Flor, frontal; C. Flor, lateral, sépalas formando um mento; D. Trichopilia brasiliensis: Flor aberta e coluna; E-F. Ionopsis utricularioides: E. Flor aberta; F. Sépalas laterais, formando pequeno mento (vista lateral); G-H. Trichocentrum albococcineum: G. Flor vista lateral, presença do esporão; H. Flor. A-C. (Bianchetti 853; Santos 1769; E-F. Walter 4235; G-H. Lima 55.) 


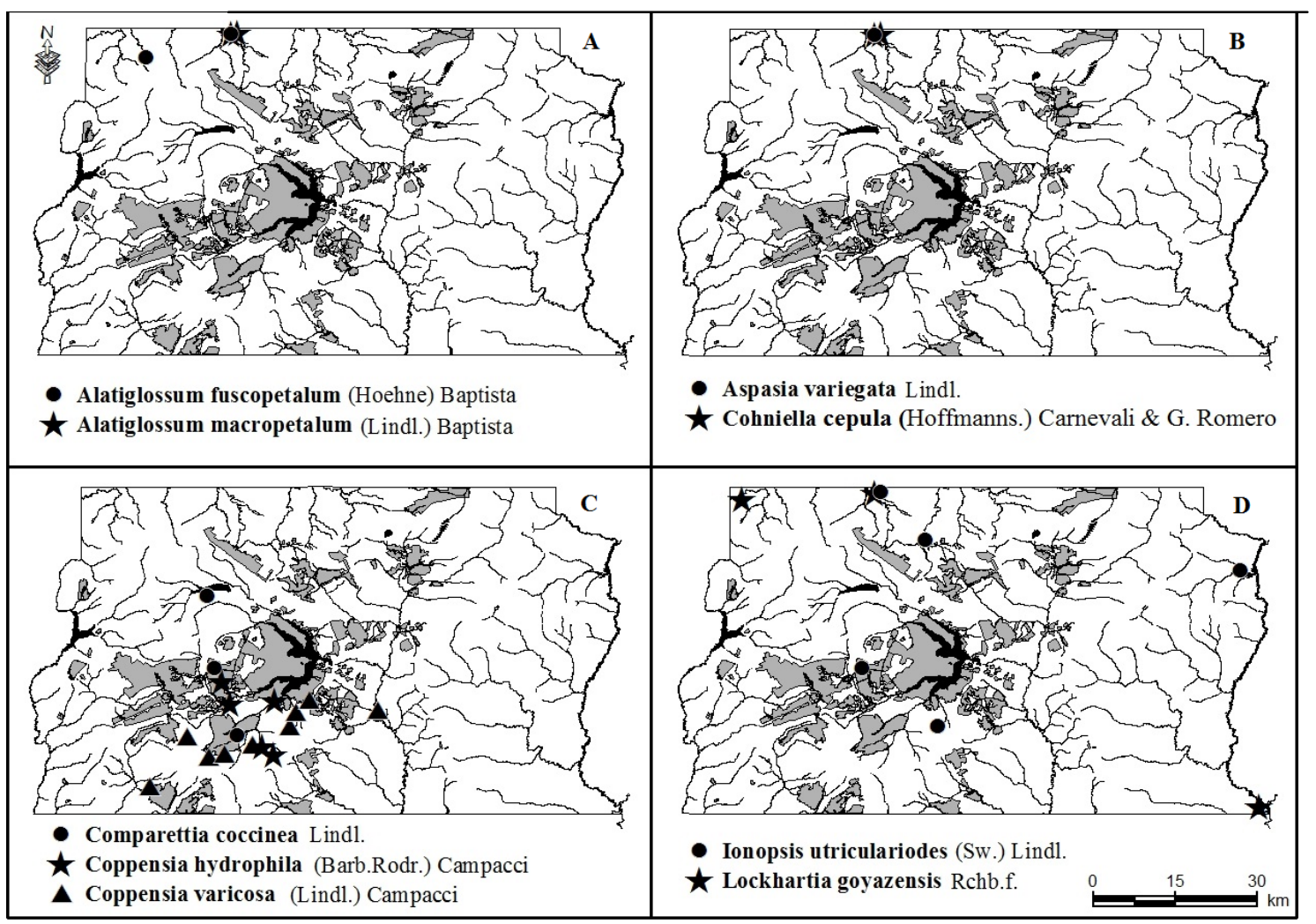

Figura 4. Distribuição de espécies de Oncidiinae no Distrito Federal, Brasil. 


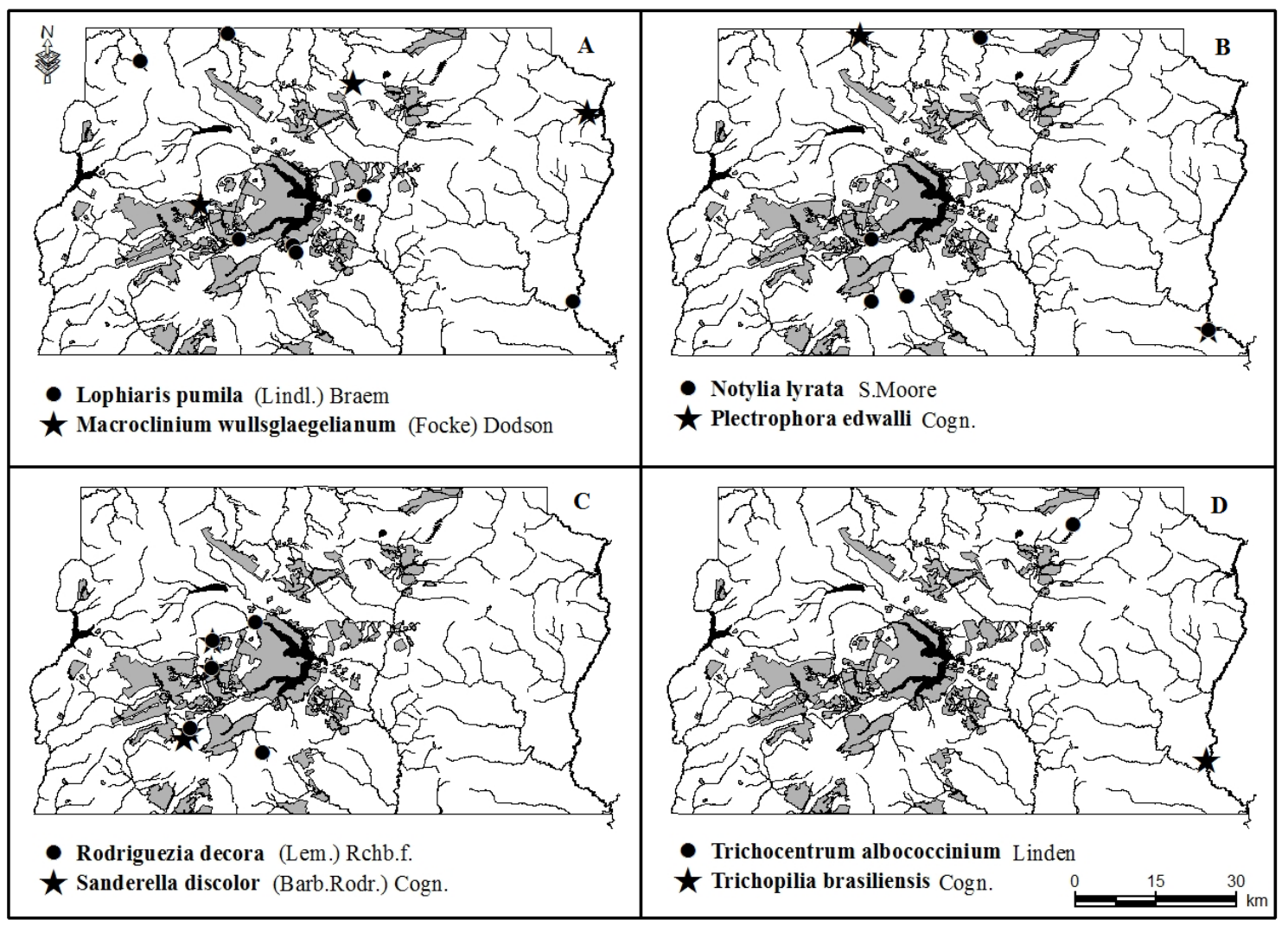

Figura 5. Distribuição de espécies de Oncidiinae no Distrito Federal, Brasil. 


\section{REFERÊNCIAS BIBLIOGRÁFICAS}

Aguiar, J.M.R.B.V. 2014. Biologia reprodutiva das Ionopsis Kunth (Orchidaceae) do Brasil. Tese de Mestrado. Universidade de São Paulo. Ribeirão Preto. 63 p.

Aliscioni, S.S.; Torretta, J.P.; Bello, M.E.; Galati, B.G. 2009. Elaiophores in Gomesa bifolia (Sims) M.W. Chase \& N.H. Williams (Oncidiinae: Cymbidieae: Orchidaceae): structure and oil secretion. Annals of Botany 14: 1141-1149.

Baptista, D.H.; Harding, P.A. \& Neto, A.D. 2011. Orchids of Brazil: Oncidiinae I. Associação Orquidófila Piracicabana. 1 edição. Brasil. P.: 21-29.

Barros, F. de \& Batista, J.A.N. 2004. Variedades, formas e outras categorias infraespecíficas em orquídeas brasileiras. In: Fábio de Barros \& Gilberto Kerbauy (Org.), Orquidologia sul-americana: uma compilação científica. p. 99-105. Secretaria de Estado do Meio Ambiente, Instituto de Botânica, São Paulo - SP. 192 p.

Barros, F. de; Vinhos, F.; Rodrigues, V.T.; Barberena, F.F.V.A.; Fraga, C.N.; Pessoa, E.M.; Forster, W.; Menini Neto, L. 2015 Orchidaceae. In: Lista de Espécies da Flora do Brasil. Jardim Botânico do Rio de Janeiro. http://floradobrasil.jbrj.gov.br/jabot/floradobrasil/FB19976 <acesso em: 24/02/2015>

Batista, J.A.N. \& Bianchetti, L.B. 2003. Lista atualizada das Orchidaceae do Distrito Federal, Brasil. Acta Botanica Brasilica 17(2): 183-201.

Batista, J.A.N.; Bianchetti, L.B. \& Pellizzaro, K.F. 2005. Orchidaceae Reserva Ecológica do Guará, Distrito Federal, Brasil. Acta Botanica Brasilica 19(2): 221-232.

Bianchetti, L.B.; Batista, J.A.N.; Pellizzaro, K.F. \& Augusto, M.M. 2005. Família Orchidaceae na APA de Cafuringa. Cap. 4.6, pp: 153-163. In: Braga Netto, P.; Mecenas, V.V.; Cardoso, E.S. (Eds.), APA de Cafuringa: a última fronteira natural do DF. Secretaria de Meio Ambiente e Recursos Hídricos. Brasília: Semarh, 2005. 543 p. : il. 
Braem, G.J., 1993. Studies in the Oncidiinae - discussion of some taxonomic problems with description of Gudrunia Braem, gen. nov. and reinstatement of the genus Lophiaris Rafinesque. Schlechteriana 1-2/93: 17-21.

Cameron, K.M., Chase, M.W., Whitten, M.W., Kores, P.J., Jarrel, D.C., Albert, V.A., Yukuwama, T., Hills, H.G., Goldman, D.H. 1999. A phylogenetic analysis of Orchidaceae: a evidence fron $\mathrm{rbcl}$ nucleotide sequences. American Journal of Botany 86: 208-224.

Carnevali, G.; Cetzal-Ix.; Balam, R.; Leopardi, C.;. Romero-Gonzalez, G.A. 2013. A combined evidence phylogenetic re-circumscription and a taxonomic revision of Lophiarella (Orchidaceae: Oncidiinae). Systematic Botany 38(1): 46-63.

Cetzal Ix, W.R.C.; Fernández-Concha, G.C.; Castro, V.P. 2012. Cohniella (Orchidaceae: Oncidiinae) South of the Amazon River. Systematic Botany, 37(1):5877.

Chase, M.W. and Palmer, J.D. 1989. Chloroplast DNA systematic of liliod monocots: Resources, feasibility, and an example from the Orchidaceae. Amer. J. Bot. 76:17201730.

Chase, M.W. 2009. Subtribe Oncidiinae. Pag. 211-391. In: Pridgeon, A.M.; Cribb, P.J.; Chase, M.W. \& Rasmussen, F.N. Genera Orchidacearum. Epidendroideae (Part Two). V. 5. Oxford. University Press.

Chase, M.W.; Williams, N.H.; Faria, A.D.; Neubig, K.M.; Amaral, M.C.E.; Whitten, M.W. 2009. Floral convergence in Oncidiinae (Cymbidieae; Orchidaceae): an expanded concept of Gomesa and a new genus Nohawilliamsia. Annals of Botany 104(3): 392 .

Christenson, E.A. 1996. Notes on neotropical Orchidaceae II. Lindleyana 11(1): 12-26. 
CRIA - Sistema de Informação Distribuídos para Coleções - Species Link http://splink.cria.org.br// <acesso: 01/06/2014>

Docha Neto, A. \& Benelli, A.P. 2006. Alatiglossum culuenense: uma nova espécie de Orchidaceae de Mato Grosso, Brasil. Orchidstudium 5:55-77.

Docha Neto, A. 2007. Sinopse taxonômica do gênero Coppensia Dumort.: descrição atualizada e chave das espécies. Orchidstudium - International Journal of Orchid Study 2(1): 14-22.

Dodson CH. 1962. The importance of pollination in the evolution of the orchids of tropical America. American Orchid Society Bulletin 31: 525-534, 641-649, 731-735.

Dodson C.H. 1965. Agentes de polinización y su influencia sobre la evolución de la familia Orquidacea. Universidade Nacional de la Amazonia Peruana. Iquitos, Peru 1$128 \mathrm{pp}$.

Dodson C.H. 2003. Native Ecuadorian Orchids. Volume 5. The Dodson Trust: Sarasota, Florida, USA.

Dodson, C.H. 2003. Why are there so many Orchid Species? Lankesteriana 7: 99-103. 2003.

Dressler, R.L. 1981. The Orchids: Natural History and Classification. Cambridge, Harvard University Press. P.: 1-154.

Dressler, R.L. \& Williams, N.H. 1982. Proposta para a Conservação da Generic Nome 1779 Oncidium Swartz (Orchidaceae) com um tipo Conserved Espécies, Oncidium altissimum Sw. Taxon 31: 752-754.

Dressler, R.L. 1993. Phylogeny and classification of the orchid family. Cambridge University Press. 
Faria A. 2004. Sistemática filogenética e delimitação dos géneros da subtribo Oncidiinae (Orchidaceae) endêmicos do Brasil: Baptistonia, Gomesa, Ornithophora, Rodrigueziella, Rodrigueziopsis e Oncidium pro parte. Tese Doutorado. Universidade Estadual de Campinas, São Paulo - SP, Brasil.

Felix L.P., Guerra M. 2000. Cytogenetics and cytotaxonomy of some Brazilian species of Cymbidioid orchids. Genet Mol Biol. 23:1-27.

Flora brasiliensis - a obra. http://florabrasiliensis.cria.org.br//, <acesso em: 02/01/2015>

Fernández-Concha, G.C., Cetzal Ix, W.R.C., Narváez, R.B., \& Romero-González, G.A. 2010. A synopsis of Cohniella (Orchidaceae, Oncidiinae). Brittonia 62(2), P.: 153-177.

Hoehne, F.C. Iconografia de Orchidaceas do Brasil. Secretaria de agricultura - São Paulo - Brasil, 1949. Pag 11-32

Garay, L.A. \& Stacy, J.E. 1974. Synopsis of the Genus Oncidium. Bradea 40(1): 393424

INCT Herbário Virtual da Flora e dos Fungos, 2014: <http://inct.florabrasil.net/> Acesso em: 15/12/2014.

Jiménez-Machorro, R. \& Carnevali, G. 2001. Nomenclatural notes: new combinations in Lophiaris Raf. (Orchidaceae). Harvard Papers in Botany 6: 283-284.

Königer, W. \& Pongratz, D. 1997. Stilifolium: a new name for the section Cebolletae of the genus Oncidium as a new genus in subtribe Oncidiinae. Arcula 7: 186-190.

Königer, W. \& Pongratz, D. 1999. Intended combination not made: Oncidium sprucei. Arcula 9: 265.

Kränzlin, F. (1922). Orchidaceae-Monandrae: Tribus Oncidiinae-Odontoglosseae, 2. In: Engler, A. (ed) Das Pflanzenreich. Wilhelm Engelman, Leipzig, 344 pp. 
Lemos, J.V.; Smidt, E.C.; Silva-Pereira, V. 2010. Visitantes florais de Gomesa recurva R. Br. em floresta ombrófila mista do Paraná. Livro de Resumos. $61^{\circ}$ Congresso Nacional de Botânica. Manaus, Amazonas, Brasil.

Lista de Espécies da Flora do Brasil. Jardim Botânico do Rio de Janeiro. Disponível em: <http://floradobrasil.jbrj.gov.br/>. Acesso em: 24/02/2015

Maury, C.M.; Ramos, A.E. \& Oliveira, P.E. 1994. Levantamento florístico da estação ecológica de Águas Emendadas. Boletim do Herbário Ezechias Paulo Heringer 1: 46-67.

Mendonça, R.C.; Felfili, J.M.; Walter, B.M.T.; Silva-Júnior, M.C.; Rezende, A.V.; Filgueiras, T.S.; Nogueira, P.E. \& Fagg, C.W. 2008. Flora vascular do bioma Cerrado. In: Sano, S.M.; Almeida, S.P.; Ribeiro, J.F. (eds.). Cerrado: ecologia e Flora. Embrapa Informação Tecnológica.

Meneguzzo, T.E.C.; Bianchetti, L.B.; Proença, C.E.B. 2012. O gênero Encyclia (Orchidaceae) no Distrito Federal, Goiás e Tocantins. Rodriguésia 63(2): 277-292.

Menezes, L.C. 1995. Rodriguezia decora var. lactea L.C.Menezes var. nov. Bol. CAOB 5(1): 11 .

Miller, D.; Warren, R.; Miller, I.M.; Seehawer, H. 2006. Serra dos Órgãos, Sua História e Suas Orquídeas. Scart, Rio de Janeiro, 574 p.

Neubig, K.M., Whitten, W.M., Williams, N.H., Blanco, M.A., Endara, L., Burleigh, J. G., Silvera, K., Cushman, J.C. \& Chase. M.W. 2012. Generic recircumscriptions of Oncidiinae (Orchidaceae: Cymbidieae) based on maximum likelihood analysis of combined DNA datasets. Botanical Journal of the Linnean Society 168: 117-146.

Nogueira, P.E.; Nóbrega, M.G.G. \& Pereira da Silva, G. 2002. Levantamento florístico e fisionomias do Parque Ecológico Ezechias Heringer (Parque do Guará) Distrito Federal, Brasil. Boletim do Herbário Ezechias Paulo Heringer 10: 31-56. 
Pansarin, E.R. \& Pansarin, L.M. 2011. Reproductive biology of Trichocentrum pumilum: an orchid pollinated by oil-collecting bees. Plant Biology (Stuttgart): 576581.

Pansarin, L.M.; Pansarin, E.R. \& Santos, I.A. 2012. Biologia floral comparativa entre duas espécies de Oncidiinae (Orchidaceae): Gomesa varicosa M.W.Chase \& N.H.Williams e Comparettia coccínea Lindl. Livro de Resumos. www.63cnbot.com.br (2012).

Parra-Tabla, V., Vargas, C.F., Magana-Rueda S., \& Navarro J. 2000. Female and male pollination success of Oncidium ascendens Lindey (Orchidaceae) in two contrasting habitat patches: forest vs agricultural field. Biological Conservation 94: 335-340.

Pellizzaro, K.F.; Batista, J.A.N. \& Bianchetti, L.B. 2004. O gênero Oncidium Benth. (Orchidaceae) no Distrito Federal, Brasil. Boletim do Herbário Ezechias Paulo Heringer 14: 128-143.

Penha, T.L.L., Corrêa, A.M. \& Catharino, E.L.M. 2011. Números cromossômicos em Kleberiella V.P. Castro \& Cath. (Orchidaceae, Oncidiinae) e gêneros afins. Acta Botanica Brasilica 25(2): 466-475.

Pereira, B.A.S.; Silva, M.A. \& Mendonça, R.C. de. 1993. Orchidaceae. In: Reserva Ecológica do IBGE, Brasília (DF): lista das plantas vasculares. IBGE, Rio de Janeiro. Pag. 35-36.

Pridgeon, A.M., Cribb, P.J., Chase, M.W. \& Rasmussen, F.N. (eds.). 1999. Genera Orchidacearum, v. 1. Oxford University Press, New York.

Pridgeon, A.M., Cribb, P.J., Chase, M.W. \& Rasmussen, F.N. (eds.). 2009. Genera Orchidacearum. Epidendroideae (Part Two). V. 5. Oxford. University Press.

Proença, C.E.B.; Munhoz, C.B.R.; Jorge, C.L.; Nóbrega, M.G.G. 2001. Listagem e nível de proteção das espécies de fanerógamas do Distrito Federal, Brasil. In: T.B. 
Cavalcanti \& A.E. Ramos (Orgs.), Flora do Distrito Federal, Brasil. Embrapa Recursos Genéticos e Biotecnologia - Embrapa Cenargen, Brasília - DF. p: 89-359.

Pupulin, F. 1995. A revision of the genus Trichocentrum (Orchidaceae: Oncidiinae). Lindleyana 10: 183-210.

Pupulin, F. \& Carnevali, G. 2005. Cohniella Pfitz. Pp. 141-147. In: F. Pupulin (ed.), Vanishing Beauty: Native Costa Rican Orchids Vol. I. Costa Rica Univ. Press, San José, Costa Rica.

Rodrigues, V.T. 2011. Orchidaceae juss. Aspectos morfológicos e taxonômicos. Instituto de Botânica, São Paulo.

Roubik, D.W. \& Ackerman, J.D. 1987. Long-term ecology of euglossine orchid-bees (Apidae: Euglossini) in Panama. Oecologia 73:321-333.

Salguero-Faria J.A.; Ackerman J.D. 1999. A nectar reward: Is more better?. Biotropica 31: 303-311.

Sandoval-Zapotitla, E. \& Terrazas, T. 2001. Leaf anatomy of 16 taxa of the Trichocentrum clade (Orchidaceae: Oncidiinae). Lindleyana 16: 81- 93.

Sarmiento J. 2007. La familia Orchidaceae en Colombia. Actualidades biológicas. IV Congreso Colombiano de Botánica. Universidad de Antioquia, Medellín-Colombia.

Senghas, K. 1998. Die Orchideen: Subtribus Oncidiinae. Berlin: Parey.

Silva, D.G. 1999. O gênero Oncidium Benth. (Orchidaceae) na chapada Diamantina, Bahia, Brasil. Tese de Mestrado. Universidade Estadual de Feira de Santana, Feira de Santana-BA. 41 p. il.

Silvera, K. 2002. Adaptive radiation of oil-reward compounds among neotropical orchid species (Oncidiinae). Unpublished M.S. thesis, University of Florida. 
Singer, R.B., \& Cocucci, A.A. 1999. Pollination mechanisms in four sympatric southern Brazilian Epidendroideae orchids. Lindleyana 14, 47-56.

Singer, R.B.; Marsaioli, A.J.; Flach, A. \& Reis, M.G. 2006. The ecology and chemistry of pollination in Brazilian orchids: recent advances. In: Teixeira da Silva J. (ed.) Floriculture, ornamental and biotechonology: advances and topical issues. Vol. IV. Isleworth: Global Science Books, 570-583 p.

Sosa, V., Chase, M.W., Salazar, G.E., Whitten, W.M. \& Williams, N.H. 2001. Phylogenetic position of Dignathe (Orchidaceae: Oncidiinae): evidence from nuclear ITS ribosomal DNA sequences. Lindleyana 16: 94-101.

Stafleu, F.A. 1985. Report of the Committee, for Spermatophyta: Proposal 679.1779 Oncidium Swartz (orchidaceae); O. altissimum Sw. typ. cons. prop. Taxon 34(4): 661.

Stpiczynska, M.; Davies, K.L.; Pacek-Bieniek, A.; Kaminska, M. 2013. Comparative anatomy of the floral elaiophore in representatives of the newly re-circumscribed Gomesa and Oncidium clades (Orchidaceae: Oncidiinae). Annals of Botany 112: 839854.

Szlachetko D.L., 1995. Systema Orchidalium. Fragm. Flor. Geobot., Suppl. 3: 1-152.

Torretta, J.P.; Gomiz, N.E.; Aliscioni, S.S.; Bello, M.E. 2011. Biologia reproductiva de Gomesa bifólia (Orchidaceae, Cymbidieae, Oncidinae). Darwiniana 49(1): 16-24.

Tropicos, 2014. Jardim Botânico de Missouri. http://www.tropicos.org// <acesso: $10 / 12 / 2014>$

UNESCO. 2000. Vegetação no Distrito Federal: Tempo e espaço. Brasília. 74 p.

Van der Pijl, L. \& Dodson, C.H. 1966. Orchid Flowers: Their Pollination and Evolution. University of Miami Press: Coral Gables, Florida, USA. 
Walter, B.M.T. \& Cavalcanti, T.B. 2005. Fundamentos para a coleta de germoplasma vegetal. Brasília, DF: Embrapa Recursos genéticos e Biotecnologia, 761 p.

Walter, B.M.T. \& Sampaio, A.B. 1998. A vegetação da fazenda Sucupira. Embrapa Recursos Genéticos e Biotecnologia, Brasília.

Warming, E. 1973. Lagoa Santa. Belo Horizonte: Ed. Itatiaia; São Paulo: EDUSP, 1973. 284p. Original de 1892. Inclui A vegetação de cerrados brasileiros, por M.G. FERRI.

Warming, E. 1892. Lagoa Santa: Et Bidrag til den biologiske Plantegeografi. Kgl. Danske Vidensk. Selsk. Skr., Raekke, naturvidensk. Or math. Afd 6(3). Kjobenhavn, Bianco Lunos Kgl. Hof-Bogtrykkeri.

WCSP (2014). 'World Checklist of Selected Plant Families. Facilitated by the Royal Botanic Gardens, Kew. Published on the Internet: http://apps.kew.org/wcsp/ <acesso: 01/06/2014>.

Weberling, F; Schwantes, H.O. 1986. Sistemática das angiospermas. In: Taxonomia Vegetal. P.:129-131. São Paulo. EPU.

Williams, N.H. 1974. Taxonomy of the genus Aspasia Lindley (Orchidaceae: Oncidieae). Brittonia 26: 333-346.

Williams, N.H.; Chase, M.W.; Fulcher, T.; Whitten, W.M. 2001. Molecular systematics of the Oncidiinae based on evidence from four DNA sequence regions: expanded circumscriptions of Cyrtochilum, Erycina, Otoglossum and Trichocentrum and a new genus (Orchidaceae). Lindleyana 16: 113-139.

Whitten, W.M., Williams, N. H., \& Chase, M.W. 2000. Subtribal and generic relationship of Maxillarieae (Orchidaceae) with emphasis on Stanhopeinae: combined molecular evidence. American Journal of Botany 87:1842-1856. 
Zimmerman, J.K., Aide, T.M. 1987. Patterns of flower and fruit production in the orchid Aspasia principissa Rchb.f. American Journal of Botany 74: 661-661. 


\begin{abstract}
ANEXO I
DESCRIÇÃO GÊNEROS

- hábito: erva

- comportamento: terrestre, epífita, rupícola (vírgula,)

- tipo de crescimento: monopodial, simpodial (ponto.)

* rizoma: aspecto, intervalo entre pseudobulbos (ponto.)

- caules secundários:
\end{abstract}

a) intumescidos em pseudobulbos (vírgula,)

- pseudobulbos: homoblástico ou heteroblástico, presença ou não de bainhas e persistência das bainhas (ponto.)

b) não intumescido em pseudobulbos (vírgula,)

- folhas: * presença ou ausência durante a floração (vírgula,)

- desenvolvimento (convolutivo, conduplicado) (vírgula,)

- formas (vírgula,)

- disposição (apical e/ou lateral em relação ao pseudobulbo, ou dísticas em relação ao caule) (vírgula,)

- articuladas ou não (ponto.)

- inflorescência: - posição (terminal, lateral) (vírgula,)

- tipo (vírgula,)

- protegida ou não por espata (vírgula,)

- quantidade aproximada e disposição de flores (arranjos densos, laxos) (vírgula,)

* tamanho em relação às folhas (ponto.)

- flores: - ressupinadas ou não (vírgula,)

- tamanho generalizado (grandes, pequenas) (vírgula,)

- sépalas: grau de similaridade com as pétalas

a) sépalas e pétalas semelhantes entre si (vírgula,)

- grau de adnação (vírgula,)

- alguma característica especial (ponto.)

b) sépalas e pétalas diferentes (vírgula,)

- tamanho das sépalas em relação às pétalas (ponto.) 
- labelo: - forma geral (inteiro, trilobado) (vírgula,)

- grau de adnação à coluna (livre, soldada até a metade) (vírgula,)

- região do disco: - presença ou não de calo (vírgula,)

- morfologia do calo (ponto.)

- coluna: - forma geral (vírgula,)

- característica geral: - alada; ápice dentado; com aurículas (vírgula,)

- prolongamento basal (pé): presente ou não (ponto e vírgula;)

- caducidade da antera (ponto e vírgula;)

- número de políneas, forma, consistência (vírgula,)

- detalhes do polinário: (presença ou ausência de caudículo, viscidio) (ponto.)

- ovário: forma

- Cápsula: - forma geral (ponto.)

\section{DESCRIÇÃO ESPÉCIES}

- comportamento: terrestre, epífita, rupícola (ponto.)

* rizoma: aspecto, intervalo entre pseudobulbos

- caules secundários:

a) intumescidos em pseudobulbos

- pseudobulbos: forma, homoblástico ou heteroblástico, coloração, tamanho $\mathrm{X}_{\text {_ }}$, presença ou não de bainhas e persistência, encimados por folhas (ponto.)

b) não intumescido em pseudobulbos

- caule: forma, coloração, tamanho _ $X_{\ldots}$ (ponto.)

- folhas: * presença ou ausência durante a floração (vírgula,)

- número de folhas (vírgula,)

- sésseis ou *pecioladas

*pecíolo __ de compr.

- forma geral, base, margens, ápice, consistência ou textura (membranáceas, coriáceas), coloração, tamanho $X_{-}$(ponto.)

- inflorescência: * tipo (quando no gênero existem mais de um tipo) (vírgula,)

- numero aproximado de flores

- tamanho total da inflorescência (pedúnculo + ráquis) (ponto e vírgula;) 
- flores: - vistosas, cheirosas, pequenas (vírgula,)

- pediceladas ou sésseis (vírgula,)

- comprimento do pedicelo + ovário (ponto.)

- sépalas: * grau de adnação (vírgula,)

- forma geral, ápice, margens, base, consistência ou textura, coloração, sépala dorsal _ $X_{\ldots}$, sépalas laterais _ $X_{\ldots}$ (vírgula,)

* alguma característica especial (ponto.)

- pétalas: - forma geral, ápice, margens, base, consistência ou textura, coloração, tamanho _ $X_{-}$(vírgula,

* alguma característica especial (ponto.)

- labelo: - forma geral (inteiro, trilobado) (vírgula,)

- coloração

- tamanho do labelo expandido (maior largura X maior comprimento) (ponto e vírgula;) ou

* lobos laterais: - forma geral (vírgula,)

- forma de apresentação (posição, patente, deflexo) (vírgula,)

- coloração, tamanho _ $X_{\text {_ }}$ (ponto e vírgula;)

* lobo mediano: - forma geral (vírgula,)

- alguma característica distintiva (ápice emarginado, margem verrucosa)

(vírgula,)

- presença ou não de istmo (vírgula,)

- coloração, tamanho _ $X_{\text {_ }}$ (ponto e vírgula;)

- região do disco: * presença de calo, nervuras salientes (vírgula,)

- morfologia do calo (ponto e vírgula;)

- base: ungüiculada ou não (vírgula,)

* tamanho do unguículo (ponto e vírgula;)

- coluna: - alguma característica especial da espécie, coloração, tamanho $\ldots$ X (ponto.) 